DOI 10.15407/mics2020.11.211

УДК 904.5(477.81/.82)"9/10"

\title{
Дмитро Бібіков,
}

кандидат історичних наук, науковий співробітник відділу археології Києва Інституту археології НАН України, завідувач відділу археології Вишгородського історико-культурного заповідника bibikov-@bigmir.net

https://orcid.org/0000-0003-4288-2091

\section{ДАВНЬОРУСЬКІ КАМЕРНІ ГРОБНИЦІ ТА ЇХ НАСЛІДУВАННЯ НА ТЕРИТОРІЇ ДНІПРОВСЬКОГО ПРАВОБЕРЕЖЖЯ: ШЛЯХИ ЕВОЛЮЦІЇ ЕЛІТАРНОГО ПОХОВАЛЬНОГО ОБРЯДУ}

Статтю присвячено специфічній категорії давньоруських поховальних пам'яток X-XI ст. Вони поєднують у собі риси як елітарних камерних гробниць доби вікінгів, так і рядових християнських захоронень початку II тис. н. е. Запропоновано об’єднати такі поховання під терміном «квазікамери», або «камери-наслідування». Виділено чотири їх типи: 1) камери 3 гробовищами; 2) наземні камери; 3) «земляні» камери 3 дерев’яним перекриттям, проте без обкладки стін; 4) «великі могильні ями» без дерев’яних конструкцій. У статті вперше проаналізовано конструктивно-обрядові риси кожного з цих типів, визначено їхні особливості.

Вочевидь, зведення класичних камерних гробниць на південноруських теренах припинилося разом із початком християнізації. Однак повністю відмовитись від цієї традиції давньоруська еліта змогла не одразу, що дістало відображення у появі камер-наслідувань. Абсолютна більшість із них усередині стаціонарних дерев’яних конструкцій містить рухоме гробовище. Цей факт суперечить основній ідеї класичних камерних гробниць як «будинків померлих» $\mathrm{i}$ свідчить як мінімум про суттєвий вплив християнського віровчення. Поширення квазікамер на території Волині, безперечно, треба пов'язувати з державницькою діяльністю Володимира Святославича, що могла супроводжуватись притоком населення («ліпших мужів») із Серед- 
1 Авдусин, Д. А., \& Пушкина, Т. А. (1989). Три погребальные камеры из Гнёздова. В История и культура древнерусского города (с. 192). Москва: Издательство МГу

2 Лесман, Ю. М. (1997). Квазикамерное погребение в могильнике Струйское на Верхней Волге и проблема происхождения древнерусских сидячих погребений. В XIII конферениия по изучению истории, экономики, литературы и языка скандинавских стран и Финляндии (с. 180183). Петрозаводск.

3 Ситий, Ю. М. (2009). Камери, «псевдокамери» та могили Чернігівського некрополя. В Чернігівські старожитності (Вип. II, с. 294). Чернігів; MüllerWille, M. (2014). The Cemetery at Bodzia in a Broader European Context. In Bodzia: A Late Viking-Age Elite Cemetery in Central Poland ( $p$. 479). Leiden-Boston: Brill; Михайлов, К. А. (2016). Элитарный погребальный обряд Древней Руси: камерные погребения IX начала XI века в контексте североевропейских аналогий. Санкт-Петербург Бранко, 91-94; Плавинский, Н. А., \& Васильев, В. М. (2018). «Погребальная камера» или нет? Возможные пути трансформации «камерного» обряда на территории Полоцкой земли в конце X-XI вв. В Археология Древней Руси: проблемы и открытия. Материалы международной конференции, посвященной 100-летию со дня рождения Д. А. Авдусина (с. 63-64).

Москва: Памятники исторической мысли.

4 Плавинский, Н. А., \& Васильев, В. М. «Погребальная камера» или нет?, 63-64. 5 Janowski, A. (2015). Groby komorowe $w$ Europie Srodkowo-Wschodniej. Problemy wybrane. Szczecin: IAE PAN, 101-108. нього Подніпров'я. За складом поховального інвентарю та аналогіями з суміжних територій їх датують у межах кінця X - першої половини XI ст.

Комплексний аналіз конструктивних особливостей і поховального інвентарю камер-наслідувань не дає змоги однозначно пов'язати їх із представниками давньоруської еліти. В межах цього регіону розглядувані пам'ятки не завжди $€$ прямим продовженням лінії розвитку класичних камерних гробниць, а лише імітують соціально престижні обрядові елементи останніх.

Ключові слова: Давня Русь, Дніпровське Правобережжя, поховальний обряд, камери-наслідування, християнізація.

Бурхливі державотворчі, релігійні, соціально-економічні та етнокультурні процеси кінця I - початку II тис. н. е. спричинили появу на теренах Східної Свропи значного розмаїття нових форм поховального обряду. Трансформації зазнали й так звані камерні гробниці ранньосередньовічної еліти - одне 3 найяскравіших культурних явищ доби вікінгів.

Останніми роками виявлення значної кількості нових пам'яток сприяло активізації дискусії щодо проблем дефініції давньоруських елітарних поховань. Стає дедалі очевиднішим, що поширений принцип поділу інгумаційних захоронень на «камерні» та «рядові», або «грунтові», є дуже умовним. Факт відсутності узгодженого понятійного апарату часто призводить до штучного розширення як географічних, так і хронологічних рамок побутування «камерного» обряду.

Свого часу Д. А. Авдусін і Т. А. Пушкіна виокремили деякі гньоздівські поховання, що за параметрами були близькими до камерних, проте не містили дерев'яних конструкцій, в особливу «проміжну» групу 1 . Ю. М. Лєсман для характеристики поховань у «великих могильних ямах» запропонував термін «квазікамери» ${ }^{2}$. стосовує це поняття для позначення ширшого кола захоронень, що, на їхню думку, не відповідають деяким критеріям виокремлення класичних камер ${ }^{3}$. В аналогічному контексті вживають термін «псевдокамери». Білоруські дослідники М. О. Плавінський і В. М. Васильєв визначають останні як «поховальні комплекси, що нагадують “чисті камери", проте не належать до їх числа». На території Полоцького князівства їх датують у межах кінця X-XI ст. ${ }^{4}$ Хронологічно близькими $\epsilon$ мор'я, яких упродовж 1990-2000-х рр. виявлено близько півсотні ${ }^{5}$. Захоронення здійснені в широких могильних ямах; більшість із них містить залишки гробовищ, іноді - у поєднанні зі стаціонарними дерев'яними кон-
Низка сучасних археологів активно заподібні пам'ятки з території Польського По- 
6 Müller-Wille, M. The Cemetery at Bodzia, 479, 481-482, 507-510.

7 Соболев, В. Ю. (2018). Камеры, домовины, гробы. Судьба североевропейской погребальной традиции в Новгородской земле XI-XII вв. В Археология Древнеи Руси: проблемы и открытия. Материалы международной конферениии, посвященной 100-летию со дня рождения Д. А. Авдусина (с. 67). Москва: Памятники исторической мысли.

8 Ситий, Ю. М. Камери, «псевдокамери» та могили, 294.

9 Ивакин, В.Г. (2011). Киевские погребения X века. Stratum plus, 5 , $16,35-36$.

10 Михайлов, К. А. Элитарный погребальный обряд, 92-93.

Puc. 1. Камерні поховання та їх наслідування на території Дніпровського Правобережжя:

а) класичні камерні поховання; б) квазікамери;

в) камери невизначеної конструкції та поховання з сумнівною атрибуцією. 1 - Судова Вишня;

2 - Підгірці; 3 - Гірка Полонка; 4 - Городище;

5 - Теремно; 6 - Новосілки; 7 - Ставок;

8-Старожуків-1, 2; 9 - Білів; 10 - Пересопниця;

11 - Понебель; 12 - Рогачів; 13 - Басів Кут;

14 - Коростень; 15 - Городськ; 16 - Вишгород;

17 - Совки; 18 - Київ; 19 - Китаїв струкціями. М. Мюллер-Вілле, усвідомлюючи певні відмінності між цими похованнями та класичними камерами, також почав, за давньоруськими аналогіями, називати їх квазікамерними («chamber-likegraves») ${ }^{6}$. У Новгородській землі в середині XI - першій половині XII ст. побутували поховання у великих могильних ямах, іноді - зі слідами дерев'яних перекриттів i/aбо внутрішньомогильних конструкцій. Тут само виявлено синхронні поховання в наземних «домовинах» порівнянних розмірів ${ }^{7}$.

Подібні тенденції щодо класифікації інгумаційних поховань останніми роками поширюються і в українській археології. Ю. М. Ситий виділяє окремі квазікамери на матеріалах чернігівського некрополя ${ }^{8}$. Схожим чином В. Г. Івакін 3-поміж елітних поховань Києва виокремлює, поряд із камерними, групу захоронень у великих могильних ямaх ${ }^{9}$.

На шляху подальших розробок у цьому напрямі стоїть певна розмитість самого поняття «квазікамери». Неважко помітити, що різні дослідники розуміють під ним (як, зрештою, і під самим терміном «камерні поховання») досить різне коло пам'яток. За визнанням К. О. Михайлова, це явище досі не має належної оцінки в історіографії ${ }^{10}$.

Ця стаття $є$ однією 3 перших спроб усебічного аналізу квазікамер як самостійної категорії давньоруських поховань та пошуку ймовірних сценаріїв трансформації елітарного поховального обряду Давньої Русі протягом X-XI ст. Для цього, передусім, потрібно окреслити коло ознак, притаманних класичним камерним гробницям, визначити спільне й відмінне між ними та псевдокамерами.

Аналіз здійснено на прикладі цілісного зрізу пам'яток досить широкого регіону Дніпровського Правобережжя (рис. 1). На світанку східнослов'янської державності ці території населяли райковецькі племена із порівняно монолітною матеріальною культурою. Поступове поширення камерного обряду чи окремих його елементів углиб слов'янського ареалу є одним із прямих відображень поширення в регіоні влади Рюриковичів.

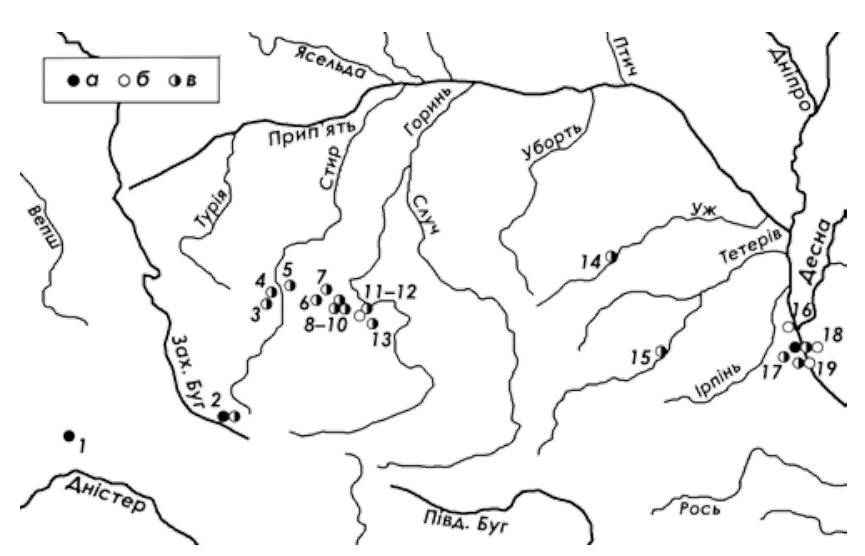



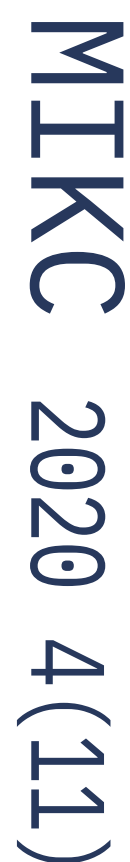

11 Бібіков, Д. В. (2019). Критерії виділення камерних поховань епохи вікінгів у Середньому Подніпров'ї: сучасний стан проблеми. В I Всеукраїнський археологічний з'їзд: матеріали роботи (с. 433-446). Київ: Інститут археології НАН України.

\section{Основні принципи класифікації}

Одна 3 перших проблем, із якою стикається дослідник, полягає у відсутності єдиних і чітких критеріїв виокремлення самих камерних поховань (у класичному розумінні) Історіографію та сучасний стан проблеми свідомо залишимо за межами цієї статті, оскільки їх було детально розглянуто в попередніх працях ${ }^{11}$.

На нашу думку, при виокремленні таких комплексів потрібно використовувати комплексний підхід, що має грунтуватись на намаганні пояснити сутність обряду, а не на наявності того чи того 3 його формальних проявів. За одностайними висновками фахівців, семантично камера символізувала житло, в якому померлий «оселявся» у потойбічному світі. Не залишають сумнівів у слушності таких висновків і писемні згадки про камерний обряд («Книга дорогоцінних скарбів» Ібн-Русте, ісландські «Сага про Егіля Однорукого і Асмунда Вбивцю берсерків», «Сага про Греттіра» тощо). Як і синхронні житлові споруди, поховальні камери мали або зрубну, або каркасно-стовпову конструкцію.

Тому ми запропонували вважати камерними лише інгумаційні поховання, які здійснено у дерев'яних імітаціях житлових будинків, споруджених безпосередньо в могильних ямах. Оскільки немає ознак дерев'яних конструкцій, метричні показники могильних ям можуть слугувати додатковим, проте в жодному разі не основним аргументом у процесі вичленування камерних гробниць.

На жаль, не завжди рівень фіксування або збереженості дерева дає змогу впевнено висновувати про конструктивні особливості поховального комплексу. Проте аналіз обрядових рис допомагає конкретизувати їх набір, не притаманний іншим ранньосередньовічним інгумаційним похованням Східної Європи, крім камерних гробниць. Оскільки надзвичайно важливим $\epsilon$ якомога повніше картографування останніх, вважаємо за потрібне розширити їх вибірку за рахунок: 1) комплексів із супутніми похованнями (як правило, жіночими) зі слідами насильницької смерті; 2) комплексів, що містять, крім людських, кістяки коней (зазвичай зі спорядженням вершника); 3) поховань зі знахідками клинкової зброї. Щодо останніх двох пунктів не беремо до уваги поховання кочовиків і представників деяких інших іноетнічних угруповань.

Як уже було сказано, на території Південної Русі відомо кілька груп поховань, споріднених із класичними камерами (до яких їх нерідко зараховують), проте, ймовірно, 
12 Седов, В. В. (1982). Восточные славяне в VI-XIII вв. Археология ССCP, 2,98 .

13 Моця, 0. П. (2019). Ще раз про елітарний поховальний обряд язичницької Русі. Археологія, 2, 51.

14 Janowski, A. Groby komorowe w Europie, 15.

Рис. 2. Зрубні гробниці на південноруських некрополях за О.П. Моцею: а) зрубні гробниці б) «склепи»; в) зруб у грунтовій могилі.

1 - Городище; 2 - Теремне; 3 - Ставок;

4 - Новосілки; 5 - Пересопниця; 6 - Колоденка;

7 - Басів Кут; 8 - Білів; 9 - Старожуків

10 - Понебель; 11 - Судова Вишня; 12 - Підгірці;

13 - Коростень; 14 - Леніно; 15 - Вишгород

16-19 - Київ і округа; 20 - Ягнятин; 21 - Клонів

22 - Седнів; 23 - Чернігів; 24 - Товстоліс

25 - Гушин; 26 - Шестовиця; 27 - Левинки;

28 - Кветунь; 29 - Жовнино

Рис. 3. Камерні поховання на території Південної

Русі за А. Яновскі: 1 - Судова Вишня;

2 - Городише; 3 - Старожуків; 4 - Білів;

5 - Пересопниця; 6 - Коростень; 7 - Київ;

8 - Совки; 9 - Китаїв; 10 - Клонів; 11 - Шестовиця;

12 - Гущин; 13 - Чернігів; 14 - Седнів;

15 - Левінка; 16 - Алефін; 17 - Кветунь; 18 - Зелений Гай; 19 - Гочево хронологічно пізніших. Усі ці «перехідні» обрядові форми не мають деяких соціально значущих рис, притаманних класичним камерам: супутніх поховань жінок і коней, знахідок клинкової зброї тощо. Головна ж відмінність полягає у самій суті поховального обряду: усі вони не несуть у собі ідею будинку померлих. Разом із тим, немає сумнівів щодо намагання учасників поховальної церемонії відтворити ті чи ті конструктивні елементи елітарних поховань більш ранньої епохи. Тому ці групи захоронень доцільно розглядати як окреме явище, об'єднавши під запропонованим Ю. М. Лєсманом терміном «квазікамери», «псевдокамери», або влучнішим «камери-наслідування». Такий принцип класифікації давньоруських інгумаційних поховань дасть змогу уникнути термінологічної плутанини та дослідницької суб'єктивності.

Найвища концентрація камер-наслідувань спостерігається на території Волині. Першим звернув увагу на їхню певну подібність до синхронних комплексів Середнього Подніпров'я ще В. В. Сєдов ${ }^{12}$. Ті $з$ них, що містили дерев'яні обкладки стін могильних ям, О. П. Моця відносить до «зрубних гробниць», не надаючи значення наявності «рухомого» гробовища ${ }^{13}$ (рис. 2). Схожої думки дотримується А. Яновскі ${ }^{14}$ (рис. 3).
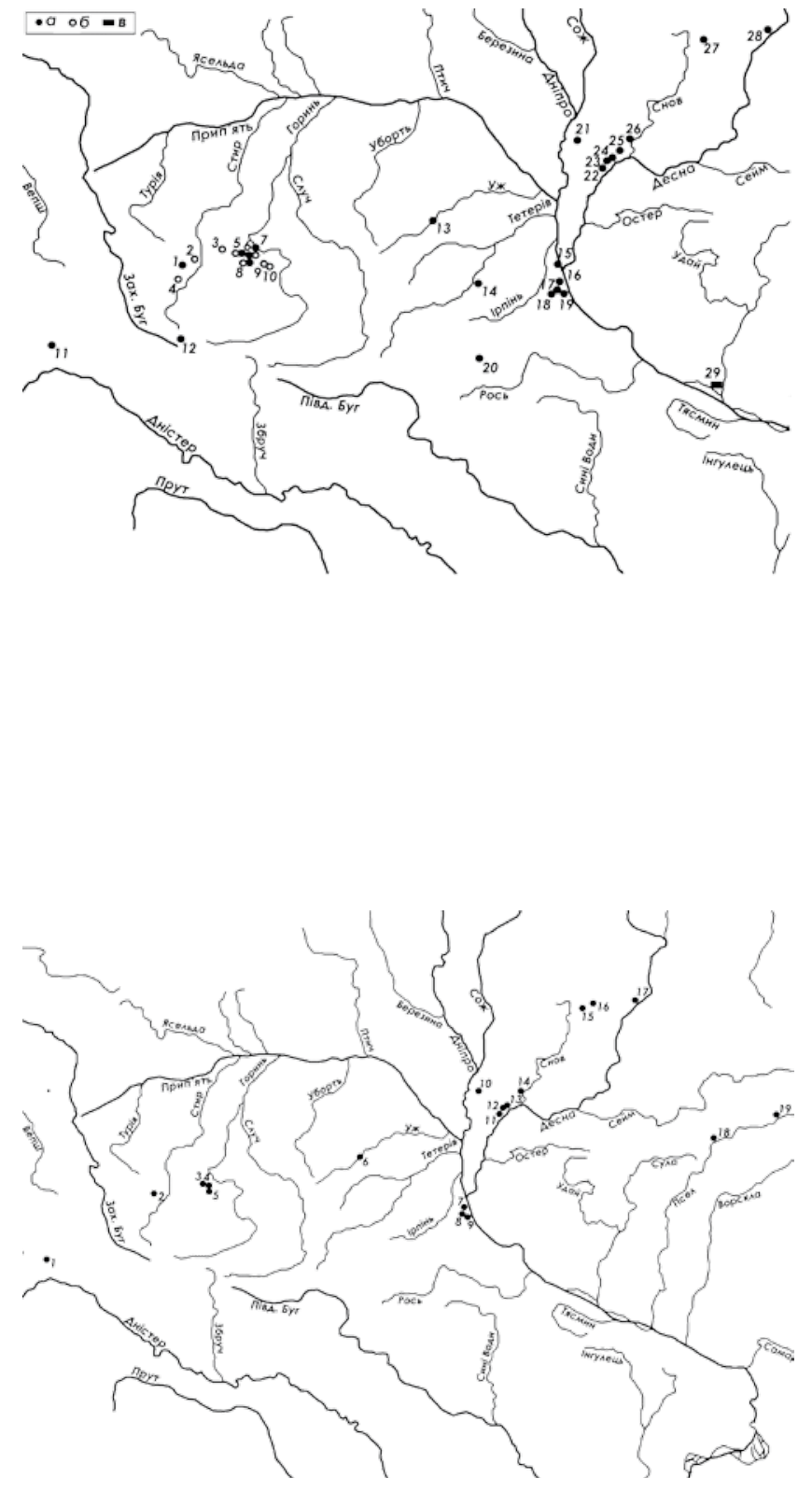
${ }_{15}$ Михайлов, К. А. Элитарный погребальный обряд, 34.

16 Ситий, Ю. М. Камери, «псевдокамери» та могили, 293.

17 Моця, О. П. Ще раз про елітарний поховальний обряд, 51.
К. О. Михайлов відносить усі ці пам'ятки до недостатньо документованих ${ }^{15}$.

На території Південної Русі можемо виокремити принаймні чотири основні групи псевдокамер (рис. 4-5):

1) камери з гробовищами. Від класичних камер вони конструктивно відрізняються лише наявністю додаткового елемента - рухомої домовини (рис. $6, a ; 12$ ). Власне, переважна більшість науковців розглядають їх як спільне явище. При цьому цілком ігнорують, наприклад, волинські матеріали. Однак Ю. М. Ситий слушно вважає появу всередині деяких камер чернігівської округи додаткової конструкції меншого розміру «еволюційною ланкою від камерних поховань язичницької епохи до появи перших могил охрещеного наприкінці X ст. населення» ${ }^{16}$;

2) наземні «склепи» (за термінологією К. М. Мельник). Ця група поховальних споруд відрізняється від попередньої розташуванням усередині підкурганного простору на рівні горизонту або на підсипці (рис. 6, б). О. П. Моця цілком аргументовано розглядає їх як пов'язані зі «зрубними гробницями», проте - осібні, пам'ятки ${ }^{17}$. Більшість поховань також здійснені в гробовищах;

3) земляні камери. Частина археологів до камерних гробниць зараховує так звані земляні камери. Іноді під цим поняттям розуміють усі інгумаційні поховання, здійснені

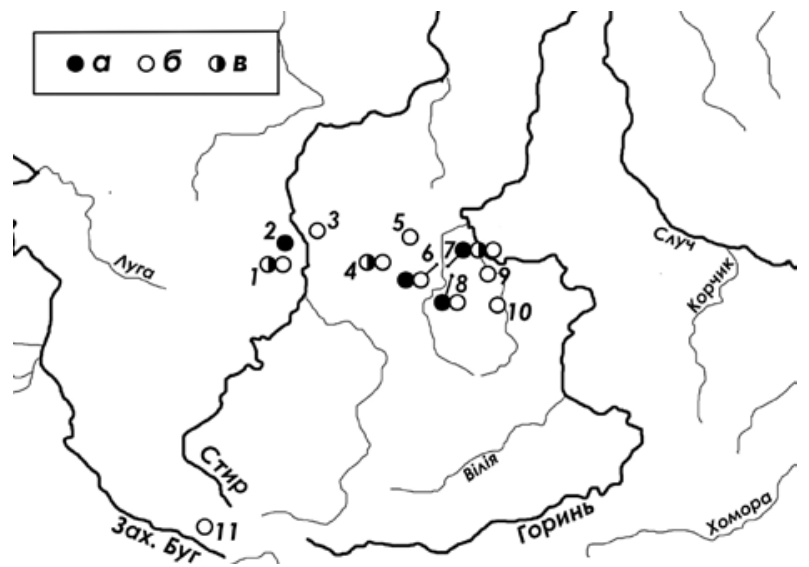

Pис. 4. Квазікамерні поховання на території Волині: а) камери з гробовищами; б) наземні склепи;

в) земляні камери. 1 - Гірка Полонка; 2 - Городище; 3 - Теремно; 4 - Новосілки; 5 - Ставок;

6- Старожуків-1, 2; 7 - Білів; 8 - Пересопниця; 9 - Рогачів; 10 - Басів Кут; 11 - Підгірці

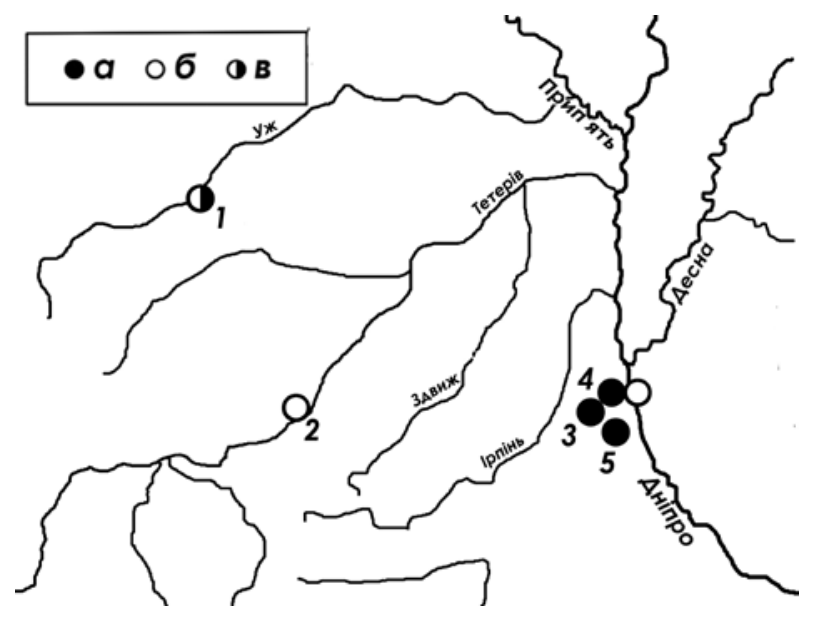

Puc. 5. Квазікамерні поховання на території Київського та Житомирського Полісся: а) камери з гробовищами; б) наземні склепи; в) земляні камери. 1 - Коростень; 2 - Городськ; 3 - Совки; 4 - Київ; 5 - Китаїв 
Pис. 6. Типи камер-наслідувань на території Волині: а) камери з гробовищами; б) наземні склепи; в) земляні камери

18 Андрощук, Ф. А. (1999). Нормани $i$ слов'яни у Подесенні. Київ: Товариство археології та антропології, 41, 42, табл. 7; Шинаков, Е. А., Гурьянов, В. Н., \& Чубур, А. А. (2011). Погребальный обряд в Среднем Подесенье как источник для исторической реконструкции. Брянск: Курсив, 35-36.

19 Жарнов, Ю. Э. (1998). Гнёздовские курганы с остатками трупоположения.

В Историческая археология. Традииии и перспективы (к 80-летию со дня рождения Даниила Антоновича Авдусина)

(с. 96). Москва: Памятники исторической мысли; Михайлов, К. А. Элитарный погребальный обряд, 60-61.

20 Івакін, В.Г. (2008). Християнські поховальні пам'ятки давньоруського Києва. Київ: КНТ, 133, 171.

21 Жарнов, Ю. Э. (1991). Женские

скандинавские погребения в Гнездове.

В Смоленск и Гнездово (с. 207-208). 217 Москва: Издательство мгу.
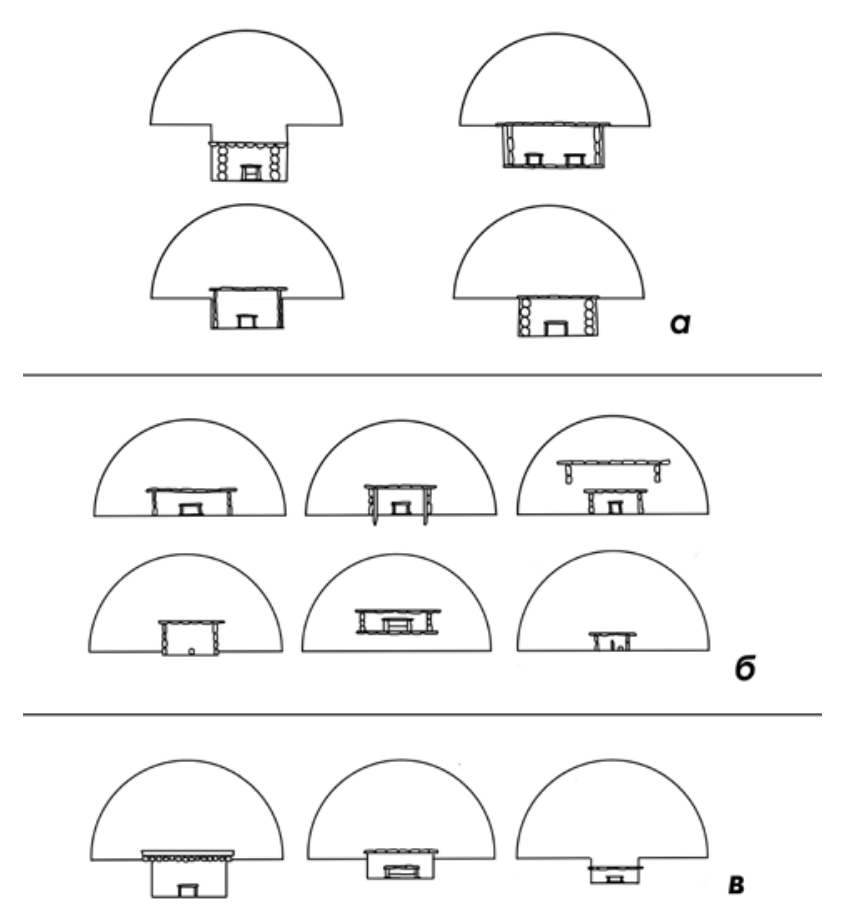

в могильних ямах великого й навіть середнього розміру ${ }^{18}$. Проте більшість науковців сприймають подібні висновки скептично і характеризують земляні камери як такі, що не мають дерев'яних стін і настилів підлоги, проте мають над могильною ямою дерев'яне перекриття, завдяки якому внутрішній простір могили залишався не засипаним землею ${ }^{19}$. В усіх волинських і середньодніпровських похованнях цього типу тіло поміщали до труни (рис. 6, в);
4) великі могильні ями. Відрізняються від земляних камер тим, що над ямою немає дерев'яного перекриття. Виокремлення конкретних поховань цієї групи є найбільш суб'єктивним порівняно 3 іншими камерами-наслідуваннями. Більшість численних спроб різних дослідників вичленити категорію захоронень у могильних ямах, «за розмірами наближених до камерних гробниць», є безпідставними. Очевидно, що для виокремлення квазікамер цієї групи потрібно сформулювати надійніші критерії. По-перше, таким критерієм має бути наявність над похованням курганного насипу. Інакше доведеться віднести до них низку міських, переважно - безінвентарних, захоронень XI-XIII ст. Зокрема, поховання № 9 Андріївського (Янчиного) монастиря в Києві було здійснене в могильній ямі завширшки 1,65 м, проте містило «подушку» 3 плінфи, що вважають проявом монастирської поховальної традиції ${ }^{20}$. Що ж до метричних показників могильних ям, то потрібно використати методику, запропоновану Ю. Е. Жарновим (на основі розробок А.-С. Грьослунд) для виділення «камер» (за його термінологією) Гньоздівського могильника. Їх ширина має становити не менше ніж 1,4-1,5 м, а співвідношення ширини до довжини - від 0,6 до $1^{21}$. Виявляється, що, наприклад, усі відомі поховання Дніпровського Лівобережжя, 
22 Мельник, Е. Н. (1901). Раскопки в земле лучан. В Труды XI Археологиче ского съезда (Т. 1, с. 520); Тимощук, Б. О. (1982). Давньоруська Буковина ( $X$ - перша половина XIV cm.) Київ: Наукова думка, 63-65.

23 Русанова, И. П. (1973). Славянские древности VI-IX вв. между Днепром и Западным Бугом. В Свод археологических источников (Вып. Е1-25, с. 39). Москва: Наука.

24 Шинаков, Е. А. (1995). От пращи до скрамасакса: на пути к державе Рюриковичей. Брянск; Санкт-Петербург: Брянский государственный университет имени академика И. Г. Петровского, 135-136.

25 Войтехович, А.В. (2019). Погребальный обряд населения Полоцкой земли в X-XII вв. Минск: Беларуская навука, 26 .

26 Лесман, Ю. М. (2014). Скандинавский компонент древнерусской культуры. Stratum plus, 5, 79; Соболев, В. Ю. Камеры, домовины, гробы, 67.

27 Кубишев, А. I. (1964). Стародавній Китаїв. Археологія, XVII, 51.

28 Cynkalowski, A. (1961). Materiazy do pradziejów Wozynia I Polesia Wozyńskiego. Warszawa: PTA, 159.

29 Гончаров, В. К. (1949). Археологічна розвідка по р. Роставиці в 1946 р. В Археологічні пам'ятки УРСР (Т. 1, с. 243). які підпадають під ці показники, розташовані на «дружинних» могильниках, що не може бути випадковістю і підтверджує правильність обраної методики. Проте в межах окресленого в цій статті регіону жодного поховання, що відповідало б зазначеним критеріям, автору наразі не відомо.

На нашу думку, під впливом камерних поховань давньоруської еліти виник іще один обряд, який, утім, типологічно до них належати не може. Мова йде про трупоспалення (нерідко - часткові), здійснені всередині широких наземних дерев'яних зрубів По одному подібному комплексу виявлено на могильнику біля с. Горішні Шерівці в Пруто-Дністровському межиріччі (курган № 2) та на Старожуківському-2 некрополі на Волині (курган № 5) ${ }^{22}$. Останній міг належати воїну. Три безінвентарні кремаційні поховання, вміщені в камери 3 обгорілих колод розмірами від 2,6×1,8 м до $4,4 \times 4,4$ м, відомі в с. Межирічка на р. Тетерів ${ }^{23}$. Аналогічний обряд трапляється і на суміжних територіях. У Кветуні в Середньому Подесенні зруб $(2,8 \times 2,2$ м $)$ iз рештками трупоспалення вміщено до неглибокої ями ${ }^{24}$. На могильнику Оцерцо під Мінськом у двох курганах Х ст. із залишками кремації виявлено обгорілі зрубні конструкції розмірами $5 \times 4,8$ м і 2,8×2,2 м, зведені, відповідно, на рівні горизонту та на невисокій підсипці ${ }^{25}$.
До «камер» Північної Русі кінця Х - першої половини XII ст. дехто з дослідників не досить обгрунтовано відносить також споруди 3 дерну, перекриті курганними насипами, безкурганні поховання у великих ямах, тощо ${ }^{26}$.

\section{Камери невизначеної конструкції та поховання iз сумнівною атрибуцією}

Щонайменше у восьми випадках можна говорити про наявність стаціонарних поховальних споруд, проте уривчастість наявних свідчень не дає змоги висновувати про їхню конструкцію (додаток, № 59-66).

Одразу кілька могил із дерев'яними обкладками стін (іноді - у поєднанні з «рухомими» гробовищами) розкопав О. Д. Ертель у Китаєві, проте не зазначив ні розміри споруд, ні, бодай, їх кількість ${ }^{27}$. Не менш лаконічною є згадка про дерев'яний зруб із людським кістяком у кургані біля с. Понебель під Рівним ${ }^{28}$. Захоронення «у дерев' яних зрубах нижче горизонту», розкопані співробітниками Бердичівського краєзнавчого музею в с. Ягнятин ${ }^{29}$, можуть належати і до раннього залізного віку.

Декілька камер невизначеної конструкції досліджено 1936 р. на садибі Дорошенка у Вишгороді. В похованні № 2, здійсненому в 
30 Мовчановський, Ф. М. (1936). Щоденник керівника Вишгородської експедиції IIMK (๑5.09-26.09.1936 р.). Науковий архів Інституту археологї̈ НАНу, ф.20, № 42, 70-71.

31 Зоценко, В. Н. (2009). Киевский некрополь II: место в исторический топографии города, типология инвентаря, хронология. В Славяно-русское ювелир ное дело и его истоки. Материалы Международной научной конференции, посвященной 100-летию со дня рождения Галины Фёдоровны Корзухиной (СанктПетербура, 10-16 апреля 2006 г.) (с. 456-457). Санкт-Петербург: Нестор-История

32 Мовчан, I. I., \& Климовський, С. I. (2002) . Дослідження «граду Ярослава» Стародавнього Києва. В Археологічні відкриття в Украӥні 2001-2002 (с . 193).

33 Лебединцев, П. Г. (1888). 0 раскопке на Софийском дворе в мае 1878 г. В Чтения в Историческом обществе Нестора-летописиа (Кн. II, Отделение 1 , с. 64); Каргер, М. К. (1958). Древний Киев (Т. 1, с. 166-167). Москва; Ленинград: Издательство Академии наук CCC.

34 Хойновский, И. А. (1893). Раскопки великокняжеского двора древнего Киева, произведенные в 1882 году. Киев: Типография С. В. Кульженко, 24.

35 Зоценко, В. Н. Киевский некрополь II, 460 .

36 Андрощук, Ф. (20๑4). Скандинавские древности в социальной топографии древнего Киева, Ruthenica, III, 39-40; Зоценко, В. Н. Киевский некрополь II 464-465. могильній ямі розмірами $1,83 \times 1,47 \times 0,7$ м $3 і$ слідами дерева, імовірно, виявлено скандинавську кільцеву фібулу. Кілька захоронень виявились зруйнованими або пограбованими: ще до початку розкопок власники садиби під час земляних робіт тричі наштовхувались на рештки давніх поховань із супровідним інвентарем: намистом, залізними сокирою та списом. Одна 3 пограбованих могильних ям мала розміри $2,2 \times 2 \mathrm{~m}^{30}$.

3 огляду на значні розміри могильної ями $(4,5 \times 3,15 \times 1,5$ м), до класичних камер, імовірно, належав «курган-могикан», або поховання 118 , із київського некрополя II ${ }^{31}$ Знахідка парних шпор може опосередковано вказувати на наявність супровідного кінського захоронення. Поховання 111, найпевніше, належало до категорії земляних камер, проте не можемо це стверджувати, оскільки немає виразних слідів перекриття Конструкцію поховальної споруди, розкопаної по вул. Рейтарській, 4, важко охарактеризувати через незадовільну збереженість дерева ${ }^{32}$.

Ще шість комплексів віднесено до категорії «сумнівних»: у цих випадках $\epsilon$ недостатньо підстав, щоб припускати наявність дерев’яних конструкцій (додаток, № 67-72).
Не завжди можна $з$ упевненістю висновувати навіть про спосіб поводження з тілом покійного.

Приміром, у київському похованні 103 на місці флігеля баштових воріт садиби Софійського собору кістки людини і коня було виявлено «у смузі вугілля». 3 огляду на збереженість кісток, М. К. Каргер піддав сумніву початкову інтерпретацію комплексу як залишків кремації ${ }^{33}$. Глибина виявлення (близько 2,8 м) від денного горизонту може свідчити про захоронення у ямі, що вказує на камерний обряд.

Майже нічого, крім наявності дощатої підлоги, не відомо про влаштування поховальної споруди в київському захороненні $107^{34}$. Те саме можна констатувати і стосовно жіночих поховань 124 і 125, хоча багатий склад та яскрава скандинавська «вуаль» інвентарю схиляють до думки про класичне камерне захоронення ${ }^{35}$. Спираючись на рукописний інвентарний опис В. Б. Антоновича та замітку А. Ф. Роговича, Ф. А. Андрощук i В. М. Зоценко розглядали (і небезпідставно) виявлені в садибі купця Й. В. Марра поховання 117 і 125 як єдиний комплекс ${ }^{36}$. У пізніших працях того ж В. Б. Антоновича чоловіче та жіноче захоронення могли бути 
37 Антонович, В. Б. (1879). Археологи ческие находки и раскопки в Киеве и в Киевской губернии в течение 1876 г. В Чтения в Историческом обществе Нестора-летопuсuуa (Кн. 1, с. 251-252); Антонович, В.Б. (1884). 0 древнем кладбище у Иорданской церкви в Киеве (о результатах раскопок, произведенных в северном углу города Киева. В Труды IV Археологического съезда в Казани (Том I, с. 43); Антонович, В. Б. (1895). Археологическая карта Киевской губернии (Приложение к $15 \mathrm{~m}$. «Древности»). Москва: Типография М. Г. Волчанинова, 31.

38 Каргер, М. К. Древний Киев, 190.

39 Мовчановський, Ф. М. Щоденник керівника, 69; Довженок, В. Й. (1950).

Огляд археологічного вивчення древнього Вишгорода за 1934-1937 рр. Археологія, 3, 90 .

40 Ратич, 0. 0. (1971). Багате поховання рубежу X-XI ст. у Судовій Вишні. В Середні віки на Україні (Вип. 1, с. 162-168). Київ: Наукова думка.

41 Liwoch, R. (2018). Zabytki z wykopalisk Teodora Nieczuja-Ziemięckiego w latopisowym Pleśnisku (Podhorce na Ukrainie) / Artefacts from Excavations by Teodor Nieczuja-Ziemięcki in Mediaeval Plisnes'k (Pidgirci in Ukraine). Kraków: Museum archeologiczne w Krakowie, 24-29, 31-39.

42 Пастернак, Я. (1948). Літописний город Пліснеськ та проблема варягів у Галичині. Науковий збірник Украӥнсько- штучно розділені, що не видається дивним, зважаючи на методику ведення робіт ${ }^{37}$. Однак не можна виключати і зворотну ситуацію, за якої речі з розташованих поруч захоронень спочатку були просто перелічені разом, як вважав М. К. Каргер ${ }^{38}$.

Про два вишгородські захоронення із садиби Дорошенка сказано лише, що їх устрій був аналогічним вищезгаданому похованню № $2^{39}$.

\section{Класичні камерні поховання}

Аналізу камерних гробниць Дніпровського Правобережжя та їх зв'язків із пізнішими формами обряду має передувати створення якомога вичерпнішої вибірки цих пам'яток. До нашого каталогу ввійшло 23 поховання, які відповідають сформульованим вище критеріям (додаток 1, № 1-23). Щодо атрибуції більшості з них не виникає особливих суперечок у сучасних дослідників; $\epsilon$, втім, i суперечливі комплекси, на яких варто зупинитись окремо.

Достатньо підстав, на нашу думку, відносити до числа класичних камерних поховання, розкопане поблизу с. Судова Вишня. Багате жіноче захоронення було здійснене в могильній ямі розмірами $2 \times 1,5$ м із залишками дерева по краях ${ }^{40}$. Немає сумнівів щодо подібної атрибуції двох парних похо- вань Підгірцівського могильника на Львівщині. Автор розкопок, Т. Земенцький, згадує «дерев’яні оббивки всередині могил» i залишки перекриття, в обох захороненнях було знайдено мечі та інший багатий інвентар, а зважаючи на пози небіжчиків, можна висновувати про значні розміри поховальної споруди ${ }^{41}$ (рис. 8, 1, 2). Ще докладніше описав облаштування зрубної гробниці, розкопаної на тому самому могильнику, Я. І. Пастернак ${ }^{42}$.

Про облаштування поховань 106, 108 , 116 і 117, випадково знайдених під час земляних робіт другої половини ХІХ ст., відомо

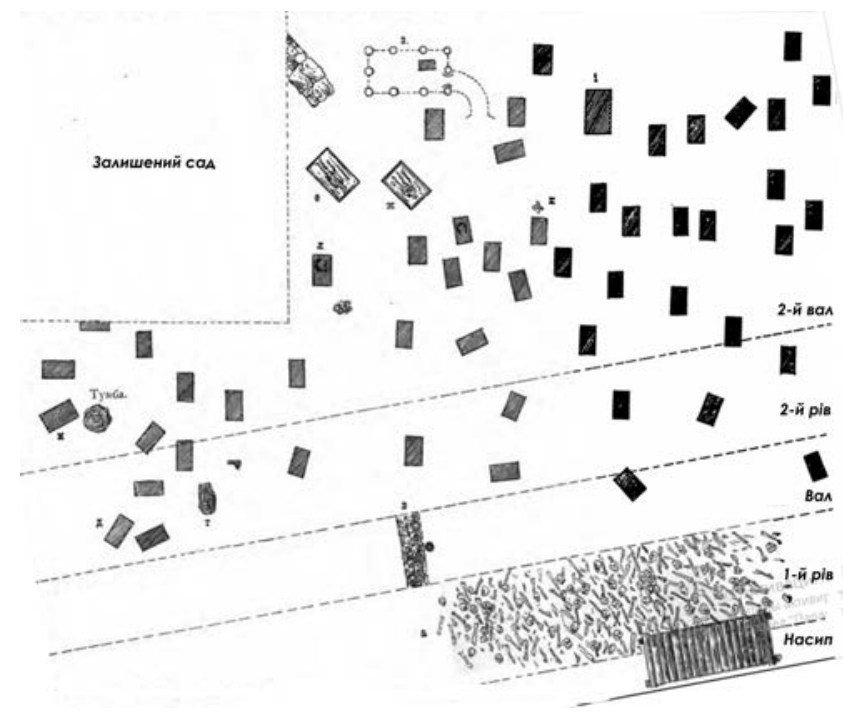

Puc. 7. Загальний план розкопок

Й. А. Хойновського в садибі Кривцова (вул. Десятинна) у 1892 p 
43 Зоценко, В. Н. Киевский некрополь II, 464.

44 Вельмин, С. П. (1910). Археологические изыскания в Императорской археологической комиссии в 1908-1909 годах на территории Древнего Киева. Военно-исторический вестник, 7-8, 152-153.

45 Голубева, Л. А. (1949). Киевский некрополь. Материалы и исследования по археологии СССР, 11, 44; Килиевич, С. Р. (1982). Детинеи Киева IX первой половины XIII в. Киев: Наукова думка, 49; Толочко, П. П. (2009). Историческая топография раннего Киева: реальная и вымышленная. Ruthenica, 8, 167-172.

46 Каргер, М. К. Древний Киев, 173.

Puc. 9. Воїнські камерні поховання з території Києва: 1 - поховання 109 2 - поховання 114 ; 3 - поховання б/№ 2002 лише те, що вони здійснені за обрядом інгумації. Проте їх можна віднести до камерних, оскільки наявні супровідні кінські захоронення. Прикметно, що у трьох із чотирьох комплексів знайдено мечі. Поховання 106 розташоване поруч із достовірно камерним № 105 (рис. 8). Поховання 116 В. М. Зоценко за складом інвентарю впевнено характеризував як парне 3 конем, здійснене у камері ${ }^{43}$.

Чимало суперечок у науковій літературі різних часів викликала атрибуція так званого поховання 109. Зрубну споруду, виявлену 1908 р. під південною апсидою Десятинної церкви, автори розкопок трактували як залишки житла («дім варяга-християнина») ${ }^{44}$ (рис. 9, 1). Таких висновків доходили й де які радянські дослідники, аргументуючи їх незвично великими (навіть для камер X ст.) розмірами об'єкта, відсутністю людських

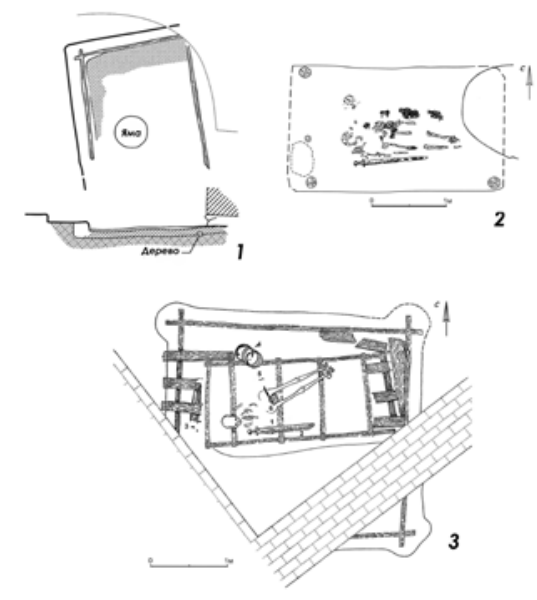

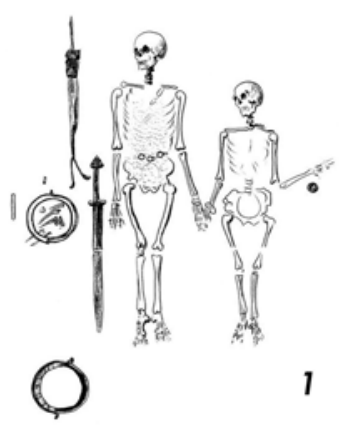
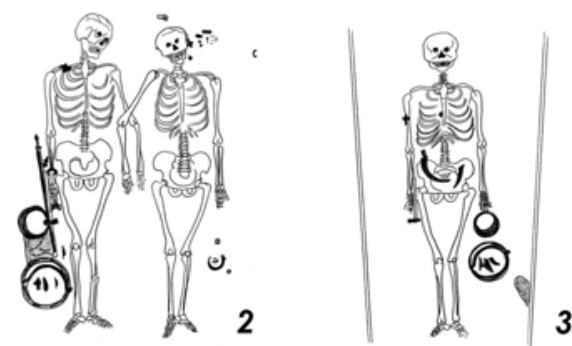

Puc. 8. Камерні та квазікамерні поховання 3 Підгірців: 1 - «великий курган на селянській ділянці»; 2 - «великий здвоєний курган» № 1;

3 - «великий здвоєний курган» № 2

решток і наявністю додаткового внутрішнього членування, що конструктивно зближало споруду з так званими п'ятистінками ${ }^{45}$. Однак проведені через сто років повторні розкопки (2006, 2008-2009 рр.), схоже, довели, що мав рацію М. К. Каргер, котрий розглядав об'єкт як зрубну гробницю, частково зруйновану та пограбовану під час будівництва Десятинної церкви ${ }^{46}$. У недокопаній Д. В. Мілєєвим частині було вперше виявлено фрагменти кісток двох особин коня, а за 
47 Ивакин, Г. Ю., Иоаннисян, 0.М. \& \& Елшин, Д. Д. (2010). Архитектурно-археологические исследования Десятинной церкви в Киеве в 2008-2009 годах. В Труды Государственного Эрмитажа (Т. 53. Архитектура Византии и Древней Руси IX-XII веков, с. 384-386). Санкт-Петербург: Издательство Государственного Эрмитажа; Івакін, Г. Ю., Іоаннісян, 0. М., Йолшин, Д. Д.,

\& Лукомський, Ю. В. (2012). Дослідження Десятинної церкви в Києві у

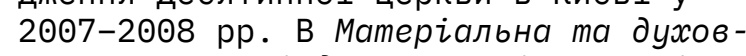
на культура Південної Русі. Матеріали Міжнародного польового археологічного семінару, присвяченого 100-літтю від дня народження В. Й. Довженка (Чернігів - Шестовиия, 16-19 липня 2009 р.) (с. 134). Київ; Чернігів: Чернігівський національний педагогічний університет імені Т. Г. Шевченка; Хамайко, Н. (2014). Камерні поховання некрополя Десятинної церкви: проблеми інтерпретації. Opus mixtum, 2, 138143.

48 Гамченко, С. С. (1927). Розко-

пи 1926 року в Києві (давніша садиба В. П. Трубецького). В Коротке звідомлення Всеукраӥнського археологічного комітету за 1926 р. (с. 29-30). Київ; Каргер, М. К. Древний Киев, 187-189;

49 Ивакин, В. Г. Киевские погребения

X века, 16; Михайлов, К. А. Элитарный погребальный обряд, 38, 250.

50 Хамайко, Н. (2018). Поховання коня

Х століття із садиби Трубецьких у Києві. Opus mixtum, 6, 118, 120.

51 Авдусин, Д. А., \& Пушкина, Т. А. Три погребальные камеры, 192.

52 Бліфельд, Д. І. (1977). Давньоруські пам'ятки Шестовиці. Київ: Наукова дум-

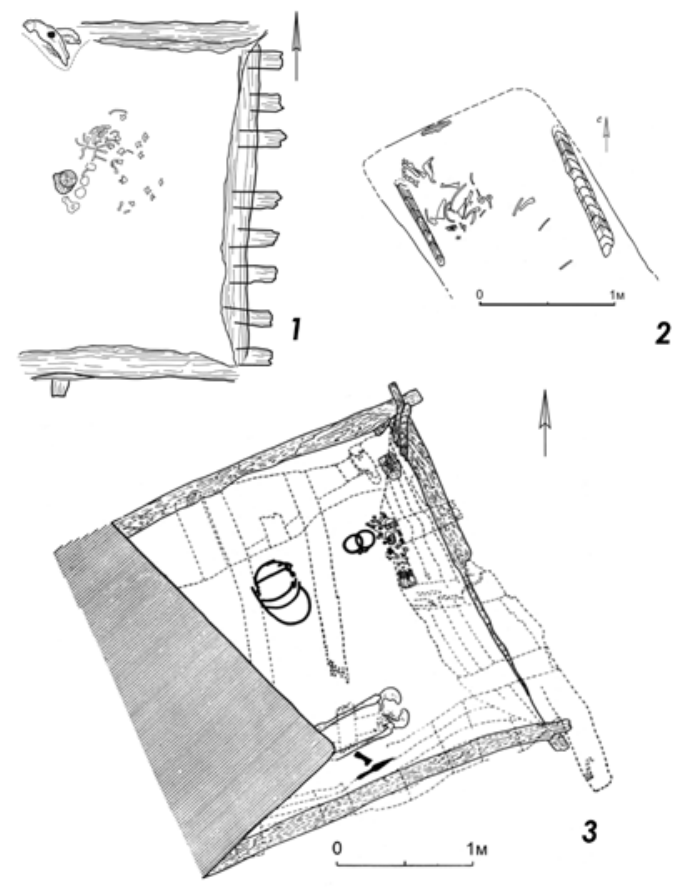

Рис. 10. Камерні поховання з супутнім захороненням коня з території Києва: 1 - поховання 112 ;

2 - поховання б/№ 1972 ;

3 - поховання 113

інформацією О. В Комара та Н. В. Хамайко частину людського черепа ${ }^{47}$. Додаткове приміщення вздовж південної стінки, наявність якого також підтверджено новими розкопками, очевидно, призначалося для супровідного захоронення коней.
Київське поховання 115, відоме як «поховання коня» ${ }^{48}$, сучасні дослідники слушно розглядають як меморативний комплекс воїнський кенотаф. В. Г. Івакін і К. О. Михайлов відносять його до категорії елітних поховань невизначеної конструкції ${ }^{49}$. Однак ретельний аналіз архівних матеріалів дав змогу Н. В. Хамайко припустити, що могильна яма мала не овальну форму, як прийнято вважати, а радше прямокутну 3 заокругленими кутами, а попід однією 3 iï стінок було зафіксовано рештки дерева ${ }^{50}$. По центру камери, між кістками коня та відром, містився порожній простір, який міг бути символічно відведеним для відсутнього небіжчика. Поховання 115 ми виділили в окрему підгрупу камер-кенотафів. Знахідки кістяків коня в бойовому спорядженні, проте без слідів людського захоронення, зафіксовано й на суміжних територіях, наприклад у Гньоздові ${ }^{51}$. В кургані № 120 шестовицького могильника поруч із конем знайдено лише верхове спорядження. На меморативний характер комплексу може вказувати нестандартне розміщення могильної ями: не по центру курганного насипу, а у стороні від нього ${ }^{52}$. В будь-якому випадку, питання наявності кенотафів серед камерних гробниць потребує докладнішого розгляду. 
53 Михайлов, К. А. Элитарный погребальный обряд, 207.

54 Килиевич, С. Р. (1973). Исследования на территории Великого княжего двора в Киеве. Археологические открытия 1972, 286; Килиевич, С. Р. Детинец Киева, 151-152.

55 Івакін, Г. Ю., Іоаннісян, О. М., Йолшин, Д. Д., \& Лукомський, Ю. В. Дослідження Десятинної церкви, 134.

56 Каргер, М. К. Древний Киев, 216-217.

57 Gräslund, A.-S. (1980). Birka IV: The Burial Customs. A study of the graves on Bjorko. Stockholm: Almqvist \& Wiksell, 7, 12 .

Puc. 11. Жіночі камерні поховання 3 території Києва: 1 - поховання $123 ; 2$ - поховання № 2/1998; 2233 - поховання № 30/1999; 4 - поховання № 49/1999
Натомість, київський комплекс із розкопок 1972 р. по вул. Десятинній, 2, який також іноді називають «похованням коня» 53 (рис. 10, 2), містив і окремі людські рештки, переміщені внаслідок пограбування могили ${ }^{54}$. В деяких пошкоджених грабіжниками комплексах (наприклад, у чернігівських похованнях із розкопок 1997 р. по вул. Фрунзе (Мстиславській), 24-А та № 29/1989 по вул. Коцюбинського, 52) імовірність початкової наявності решток людини також не можна відкидати.

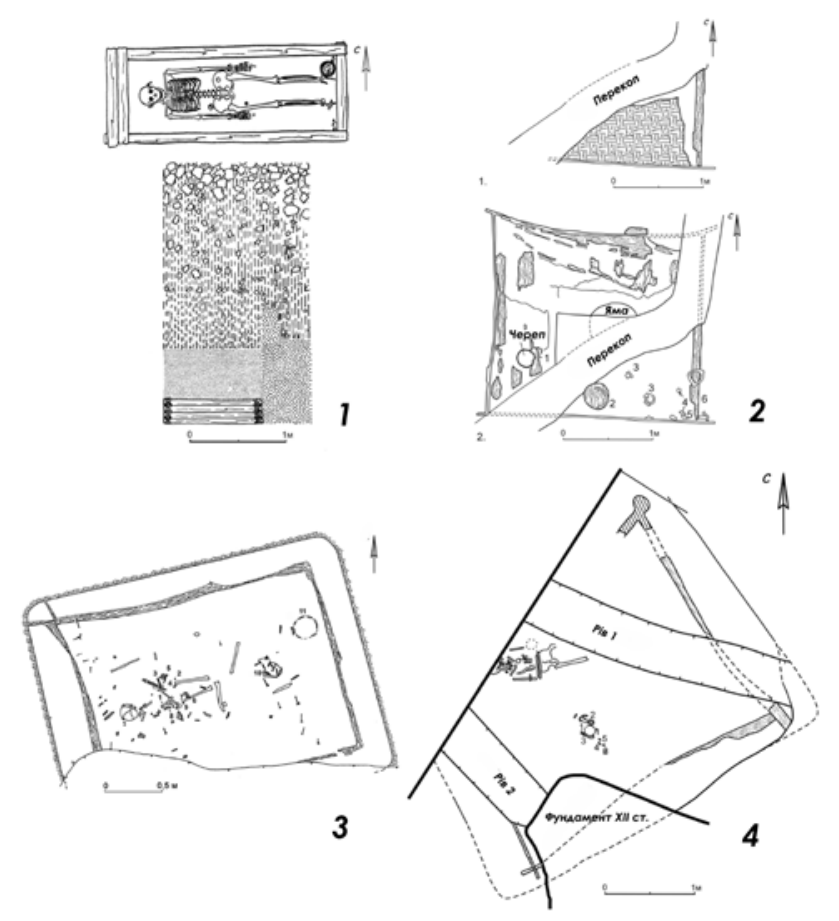

Перш ніж перейти до аналізу конструктивно-обрядових особливостей камерних гробниць Дніпровського Правобережжя, необхідно зауважити неоднаковий рівень інформативності наявних комплексів. Дослідники XIX - початку XX ст. описували конструкцію «зрубних» гробниць Києва та Підгірців лише побіжно, звертаючи основну увагу на їхній багатий речовий набір. Крім того, в умовах щільної міської забудови Києва значна кількість поховань на момент розкопок виявились тією чи іншою мірою пошкодженими. Різним є і ступінь збереженості дерева.

Розміри більшості поховальних споруд варіювалися у межах від $2 \times 1,5$ до $4 \times 4$ м. Глибина могильних ям також була різною: від 0,45 до 1,4 м. Одну з найбільших давньоруських камер $(5,8 \times 5$ м) зафіксовано в похованні № 109 під апсидами київської Десятинної церкви ${ }^{55} .3$ іншого боку, вирізняється розташоване неподалік поховання № 123, що за всіма ознаками належить до категорії камерних, проте від їхньої основної маси це захоронення відрізняється значно меншими розмірами $-2,5 \times 1$ м ${ }^{56}$. Отже, як уже було сказано, запропоновані А.-С. Греслунд критерії виділення камерних гробниць за метричними показниками могильних ям ${ }^{57}$ у східноєвропейських реаліях виявилися недієвими. 
58 Жарнов, Ю. Э. Гнёздовские курганы, 95.

59 Мовчан, І., Боровський, Я., \& Гончар, В. (2003). Нові знахідки з дружинного некрополя Верхнього Києва.

В Дружинні старожитності Централь-

но-Східної Європи VIII-XI cm.

(с. 115). Чернігів: Сіверянська думка.

60 Михайлов, К. А. Элитарный погребальный обряд, 56-57.

61 Івакін, В. Г. (2012). Київські поховальні камери. В Матеріали Міжнародного польового археологічного семінару, присвяченого 100-літтю від дня народження В. И. Довженка (Чернігів-Шестовиия, 16-19 липня 2009 р.)

(с. 124). Київ; Чернігів: Чернігівський національний педагогічний університет імені Т. Г. Шевченка.

62 Андрощук, Ф., Панченко, М., \& Ковалюх, М. (1996). До передісторії спорудження Десятинної церкви (хронологічний аналіз поховальних комплексів). В Церква Богородииі Десятинна в Києві. До 10๑९-ліття освячення (с. 43). Київ: АртЕк.
Камери зрубної конструкції на території Давньої Русі поширені більше, що і зумовило тривале побутування терміна «зрубні гробниці» для означення всієї групи пам'яток. У межах досліджуваного регіону достовірно зафіксовано принаймні 15 подібних комплексів. У випадках, коли стіни камер збереглись лише у вигляді тліну, про зрубну конструкцію може свідчити відсутність кутових ямок. Щонайменше п'ять разів для надійнішого кріплення стін або перекриттів камер використовували залізні цвяхи (Підгірці, «великий курган на селянській ділянці» (далі - ВКСД); Київ, № 110, 113, 123, 30/1999).

За способом кріплення кутів зруби можна поділити на рублені «в обло» та «в лапу». Перший із них, у якому задля зберігання тепла кінці колод або дощок виступали за межі зрубу, був традиційним для синхронних зрубних жител. Рубку «в лапу» здійснювали без залишків на кінцях i, як правило, використовували для будівництва господарських споруд. Така техніка давала змогу не лише зекономити деревину, а й копати могильну яму менших розмірів. Саме вона домінувала для камер зрубної конструкції як на території Русі, так і в Скандинавії ${ }^{58}$. На цьому тлі вирізняється київський Некрополь I, де серед зрубних камер цілковито переважали зведені в техніці «в обло» (щонайменше сім випад- ків). Їх споруджували або з колод діаметром 0,16-0,2 м, або з горизонтальних дощок чи брусів завширшки від $0,1-0,12$ до 0,17-0,2 м. Другий варіант представлений чотирма похованнями (№ 2/1998, 30/1999, 49/1999, б/№ 2002), які розташовані за межами «Міста Володимира» або на самій його периферії, що може свідчити про певну хронологічну (?) закономірність (рис. 11, 2-4). Дошки чи колоди на 0,1-0,2 м, а іноді - на 0,3-0,35 м (поховання б/№ 2002) виступали за межі зрубів. У материкових стінках могильної ями поховання б/№ 1988 р. під замки зрубу було викопано додаткові заглиблення ${ }^{59}$. Крім Києва, рубка «в обло» переважала в камерах Пскова та його округи, на решті давньоруських могильників фіксують у поодиноких випадках ${ }^{60}$.

Поховання № 123 біля Десятинної церкви вирізняється не лише меншими розмірами, а й технічними прийомами: це єдина київська камера, рублена «в лапу» ${ }^{61}$ (рис. 11,1$)$. Для цього використано колоди діаметром $0,1 \mathrm{M}$. Надійно датоване 970-980-ми рр. (нижню дату визначено за дирхемом саманідського еміра Мансура I 961-976 рр., верхня відповідає початку будівництва Десятинної церкви у 889 р. ${ }^{62}$ ), поховання № 123 є однією з найпізніших камер некрополя. Цілком імовірно, що тенденція до зменшення параметрів поховальних споруд стала одним із проявів 
63 Каргер, М. К. (1947). Киевская экспедиция (1846 г.). Краткие сообщения Института истории материальной культуры АН СCCP, XXI, 39.

64 Івакін, Г. Ю., \& Козюба, В. К. (2003). Нові поховання X-XI ст. Верхнього Києва (з розкопок Архітектурно-археологічної експедиції 19971999 рр.). В Дружинні старожитності Центрально-Східної Европи VIII-XI cm. (с. 40-41). Чернігів: Сіверянська думка.

65 Боровський, Я. $€$., \& Калюк, 0. П. (1993). Дослідження київського дитинця. В Стародавній Київ. Археологічні дослідження 1984-1989 рр. (с. 8-9). Київ: Наукова думка.

66 Михайлов, К. А. Элитарный погребальный обряд, 60.

67 Івакін, Г. Ю., Іоаннісян, О. М., Йолшин, Д. Д., \& Лукомський, Ю.В.Дослідження Десятинної церкви, 134.

68 Боровський, Я. Є., \& Калюк, 0. П. Дослідження київського дитинця, 8-9.

69 Мовчан, І. І., Боровський, Я. Є., Гончар, В. М., \& Ієвлев, М. М. (2003). Дослідження в «Городі» Володимира Стародавнього Києва. В Археологічні відкриття в Україні 2001-2002 (с. 202). спрощення цього обряду на фінальному етапі його існування.

Каркасно-стовпова конструкція камери на Дніпровському Правобережжі трапилася лише в київському похованні № 114, де по кутах зафіксовано три ямки від стовпів діаметром 0,15-0,2 м, глибиною 0,45-0,5 м ${ }^{63}$ (рис. 9, 2). Оскільки ямки звужувалися донизу, можна припустити, що попередньо загострені стовпи вбивали в землю. Каркасно-стовпова конструкція $є$ більш характерною для Скандинавії загалом і могильника Бірки зокрема. На території Давньої Русі найвищий відсоток споруджених у такій техніці камерних поховань демонструють некрополі Шестовиці та Чернігова.

Першим етапом спорудження дерев'яної гробниці було облаштування підлоги (яка, втім, не була обов'язковим елементом поховальних камер). Ї̈̈ залишки зафіксовано у п’яти випадках (Підгірці б/№, Київ № 105 , $110,113,2 / 1998,30 / 1999)$ у вигляді деревного тліну або решток горизонтальних дощок. Приміром, долівку камери київського поховання № 30/1999 було викладено поперечними дошками завширшки $0,15-0,2$ м ${ }^{64}$. У камері №2/1988 підлогу підмазано глиною ${ }^{65}$, що є більш характерним для камер Північної Русі, зокрема - Гньоздівського некрополя ${ }^{66}$.

Зрідка фіксують елементи внутрішнього членування поховальних камер. Уздовж пів- денної стінки гробниці київського поховання 109 простежено додаткове приміщення завширшки 1,1 м із фрагментами двох кінських кістяків. Приміщення було відокремлене від основного простору камери додатковою колодою і мало підсипку зі щільної сіро-блакитної глини ${ }^{67}$. Квадратна у плані камера № 1/1988 по вул. Великій Житомирській, 2 була розділена навпіл дошкою-перегородкою, що відділяла чоловіче захоронення від решток коня ${ }^{68}$. Отже, в обох випадках розмежування внутрішнього простору пов'язане $з$ супровідним захороненням коня, що добре узгоджується з ідеєю житлового будинку, в якому «оселявся» небіжчик.

Унікальну конструктивну деталь зафіксували при розкопках по вул. Великій Житомирській, 2 у 2002 р. На дні камери розміром $3,2 \times 3$ м виявили залишки нош, на які було покладено тіло померлого та частину інвентарю. Вони являли собою конструкцію розміром $2,15 \times 1,3$ м із двох поздовжніх і трьох поперечних колод діаметром 8, 10-12 см, скріплених між собою ${ }^{69}$ (рис. 9, 3).

Обов'язковим конструктивним елементом камерних поховань, на наш погляд, $є$ верхнє перекриття, яке імітувало стелю житла і забезпечувало вільний, не засипаний простір усередині. Попри те, що саме перекриття збереглося менш ніж у половині камер Дніпровського Правобережжя (Підгірці, 
70 Івакін, Г. Ю., \& Козюба, В. К. Нові поховання X-XI ст., 40.

71 Liwoch, R. Zabytki z wykopalisk Teodora Nieczuja-Ziemięckiego, 31.

72 Каргер, М. К. Древний Киев, 178, $182,187$.

73 Михайлов, К. А. Элитарный погребальный обряд, 58-59.

74 Там же, 84-85. «великий здвоєний курган» (далі - ВЗК) № 1, № 112) накат складався 3 двох рядів взаємно б/№; Київ № 105, 110, 113, 114, 123, 2/1998, п перпендикулярних колод ${ }^{72}$.

б/№ 2002), на його наявність можуть указувати опосередковані дані. Зокрема, у похованні № 30/1999 біля Михайлівського Золотоверхого собору вздовж західної та східної стін камери виявлено близько двох десятків цвяхів, що, на думку авторів розкопок, свідчить про існування поперечних брусів, які тримали перекриття ${ }^{70}$. Для більш надійного кріплення перекриттів слугували вирізки у грунті по краях могильної ями - «заплічки», зафіксовані в похованні б/№ 2002 р.

Зазвичай для спорудження перекриття використовували дошки або плахи, покладені за довгою віссю камери чи перпендикулярно їй. Таке виконання даху характерне для більшості давньоруських камер, зокрема «великого здвоєного кургану» № 1 із Підгірців $^{71}$. Натомість, у Києві, майже в усіх випадках, коли вдавалося визначити конструкцію перекриття (крім поховання № 2/1998), воно являло собою накат із колод. Ця специфічна риса виокремлює київські камерні гробниці серед подібних пам'яток Східної Свропи, поодинокі аналогії $\epsilon$ в матеріалах того-таки Псковського некрополя. Колоди мали діаметр від 0,1 (поховання № 123) до 0,2 м (поховання 2002 р. на Великій Житомирській, 2). У похованнях № 113 і 114 (а можливо -
Згідно з реконструкцією К. О. Михайлова, в київських похованнях № 112 і 30/1999 перекриття додатково підтримувалося за рахунок центрального опорного стовпа. Така конструкція передбачає наявність однієї чи двох тримальних балок ${ }^{73}$.

Крім того, дослідник вважає сталим елементом давньоруських поховань у камерах, притаманним більшості з них, сліди вогнища на перекритті ${ }^{74}$. Однак серед матеріалів південноруських земель такий висновок не знаходить вагомих підтверджень. Лише двічі згадано скупчення вугілля на рівні горизонту або в заповненні могильної ями, які бодай якось можна пов'язати 3 перекриттям (Підгірці ВЗК № 1; Київ № 114)

У восьми чи дев'яти київських камерах (№ 106, 108, 109, 112, 113, 117, б/№ 1972, № 1/1988, можливо - № 116) знайдено супровідні захоронення коней (рис. 10). Як правило, їх клали до могили загнузданими та осідланими. Кінські кістки 3 поховання № 109 належали двом різним особинам. Як і в похованні № 1/1988, їх знайдено в окремому приміщенні, про що йшлося вище. На жаль, у більшості випадків низький рівень фіксування або збереженості комплексів не дає змоги встановити початкове положення 
75 Петрухин, В. Я. (1993). Варяги и хазары в истории Руси. Этнографическое обозрение, 3, 75-76.

76 Михайлов, К. А. Элитарный погребальный обряд, 77.

77 Там же, 73-74, 210.

78 Хойновский, И. А. Раскопки великокняжеского двора, табл. I, рис. 2

79 Ливох, Р. (2010). Большие курганы летописного Плеснеска. В Славяно-русское ювелирное дело и его истоки. Материалы Международной научной конферениии, посвященной 100-летию со дня рождения Галины Фёдоровны Корзухиной (Санкт-Петербург, 10-16 апреля 2006 г.) (с. 146-489). Санкт-Петербург: Нестор-История.

80 Івакін, Г. Ю., \& Козюба, В. К. Нові поховання X-XI ст., 50, рис. 6. кінських скелетів щодо людських. Як видно $з$ плану розкопок Й. А. Хойновського, у похованні № 106 вони лежали паралельно, головами в один бік. У розграбованому захороненні № 112 таке саме розташування кінського кістяка реконструйовано за знахідками черепа та шийних хребців, а в похованні № 113 - за взаємним розміщенням деталей кінського спорядження. Таке положення $є$ проявом місцевої поховальної традиції, адже у Скандинавії коней клали винятково в ногах небіжчиків. Іноді цю традицію пов’ язують із впливами кочовиків ${ }^{75}$.

Лише у 12 випадках можна з упевненістю говорити, що поховання були одиночними. За складом інвентарю i антропологічними даними можна констатувати, що 11 захоронень належить чоловікам і хлопчикам, п’ять - жінкам і дівчатам. Ще принаймні у п'яти гробницях виявлено парні захоронення (Підгірці ВКСД, ВЗК № 1; Київ № 112, 114, б/№ 1988, можливо - № 117). Одне 3 них (№ 112) містило і скелет коня (четверна група дружинних поховань, за Д. І. Бліфельдом). Проте варто нагадати, що з огляду на наявність кількох зруйнованих комплексів ці цифри явно є заниженими. В усіх трьох випадках, коли вдавалося простежити взаємне положення кістяків, жіночий лежав по ліву руку від чоловічого. Залежна поза жінок у парних камерних похованнях переконливо вказує на супровідну роль, що відводилась їм у церемонії, власне - роль предмета поховального інвентарю ${ }^{76}$.

Як і в більшості давньоруських камерних гробниць, небіжчиків частіше ховали головами на захід (10 поховань, 14 кістяків), ураховуючи сезонні відхилення. Лише в окремих київських комплексах зафіксовано північно-східне (№ 105, 106), південне (№ 123, 2/1988) та східне (№ 113) орієнтування. Переважну більшість поховань (принаймні десять) здійснено у випростаному на спині положенні, 3 витягнутими ногами. 3 огляду на мішане розташування людських решток $і$ зміщення деталей костюма, К. О. Михайлов вважає за можливе реконструювати сидяче положення тіл похованих у київських захороненнях № 110, 112 і 30/1999 77 . Лише зрідка збереженість кісток і рівень фіксації дають змогу висновувати про положення рук небіжчиків. У трьох випадках верхні кінцівки було випростано вздовж тіла (Судова Вишня б/№, Київ № 114, 123). Як випливає із плану розкопу, в такій самій позі було знайдено скелети 3 київських поховань 105 і $106^{78}$. В обох парних похованнях Підгірців руки чоловічих і жіночих кістяків було схрещено ${ }^{79}$. У похованні № 49/1999 праву руку небіжчиці зігнуто в лікті та покладено в ділянку поперека ${ }^{80}$, в чому ми вбачаємо бузсумнівні впливи християнської поховальної традиції. 
81 Ивакин, В.Г. Киевские погребения Х века, 18-27; Михайлов, К. А. Элитарный погребальный обряд, 95-126;

Liwoch, R. Zabytki z wykopalisk Teodora Nieczuja-Ziemięckiego, 32-38.
Склад інвентарю поховальних камер Дніпровського Лівобережжя детально розглянуто у працях В. Г. Івакіна, К. О. Михайлова, P. Лівоха ${ }^{81}$, тому зупинимося лише на його загальній характеристиці. Не враховуючи частково зруйновані та пограбовані комплекси, за кількістю предметів інвентарю камерні гробниці Дніпровського Правобережжя можна згрупувати таким чином: у чотирьох похованнях знайдено від 5 до 7 предметів, у п'яти - від 10 до 14, у трьох - від 17 до 25 Навіть деякі порушені захоронення (Київ, б/№ 1988, № 2/1998, 12/1999) містили понад десять збережених артефактів.

Абсолютно всі чоловічі та парні захоронення (16 випадків) містили предмети озброєння або їх набори. 3-поміж них трапляються мечі (8 випадків), списи (5 випадків), сокири (4 чи 5 випадків), луки (2 випадки), сагайдаки зі стрілами чи окремі стріли (9 випадків). У захороненні хлопчика-підлітка (Київ № 110) справжню зброю замінено набором мініатюрних предметів - сокиркою та двома оселками. Серед захисного спорядження траплялися шоломи (2 достовірні і 2 непідтверджені випадки), кольчуги (1 достовірний і 2 непідтверджені випадки) та щити (2 випадки). До воїнських атрибутів належать також поясні набори, виявлені в семи комплексах, і гральні набори (Київ, № 108 , 110). Чоловічі прикраси та елементи костю- ма представлені срібними кільцеподібними фібулами 3 довгою голкою (Київ № 108, 112 , 116), витою шийною гривнею зі срібла (Київ № 106), срібним гранованим браслетом (Підгірці В3К № 1), гудзиками, від двох до дев’яти (4 випадки), перснями (2 випадки).

Для інвентарю основних і супровідних жіночих поховань (10 випадків) характерні намиста різних комбінацій (8 випадків), персні або вставки до них (7 поховань, 16 екземплярів). Важливо зауважити часті знахідки скроневих кілець (7 випадків) - типово слов'янських жіночих прикрас. Зрідка трапляються очілля із золотим або срібним шитвом (Київ № 123, 49/1999), золоті або срібні браслети (Судова Вишня б/№, Підгірці ВКСД, Київ 123), срібна фібула типу «Терслев» (Київ № 49/1999), підковоподібна фібула зі срібла (Київ № 123), срібна ремінна пряжка (Київ № 49/1999), шість гудзиків (Судова Вишня б/№).

Серед інших знахідок, характерних для камерних поховань, як чоловічих, так і жіночих, - скандинавські фібули (4 випадки), скрині (Київ, № 2/1998 (?), 30/1999, 49/1999) та сумки (Київ, №49/1999, б/№ 2002). Виключно із київських поховань походять знахідки монет: арабських (6 випадків) і візантійських (1 випадок). Незалежно від статі похованих, поширеними $є$ побутові предмети - відра (10 випадків), ножі (9 випад- 
82 Каргер, М. К. Древний Киев, 210.

83 Бібіков, Д. В. (2020). Релігійна належність давньоруських камерних поховань. Археологія, 1, 61-71.

84 Лесман, Ю. М. Скандинавский компонент, 79; Михайлов, К. А. Элитарный погребальный обряд, 91, 180, 182; Соболев, В. Ю. Камеры, домовины, гробы, 66.

85 Liwoch, R. Zabytki z wykopalisk Teodora Nieczuja-Ziemięckiego, 28, 39; Ратич, 0.0. Багате поховання рубежу $\mathrm{X}$ XI CT.

Puc. 12. Камери з гробовищами з території Києва та Китаєва: 1 - Київ, поховання б/№ 1984; 2 - Китаїв, курган № 1/1973; 3 - Китаїв, курган № 2/1973, ків), кухонні горщики (3 випадки), гребені (3 випадки), ключі (3 випадки). У чоловічих похованнях знайдено серп (Київ б/№ 1988), терези (Київ № 110), оселки (5 випадків), у жіночих - глиняне пряслице (Підгірці ВЗК № 1), ножиці, пінцет (Київ № 49/1999). Поодинокими знахідками $є$ кістяна орнаментована ложечка (Київ № 110), бронзова напівсферична чаша (Київ № 49/1999), дві дерев'яні чаші зі срібними накладками Київ, б/№ 1988), дерев’яна чаша (Підгірці ВЗК № 1), амфора та миска (Київ № 106).

У чотирьох гробницях виявлено християнські символи (8 предметів): хрестоподібні підвіски та накладки, енколпіон, дирхеми 3 графіті у вигляді хреста. Ще три подібні знахідки походять із «сумнівних» камер № 124 i $125^{82}$. Їх семантичний зміст ми детально розглянули в окремій статті ${ }^{83}$. Іншим різновидом амулетів є просвердлені ікла вепря (Підгірці, ВЗК № 1, Київ № 106, 110), які трапляються і разом з хрестиками. В обох парних похованнях Підгірцівського могильника до рота померлих було покладено по золотій бляшці - «оболи мертвих».

Побутування класичних камерних поховань на території Давньої Русі визначають у межах X ст. ${ }^{84}$ Абсолютно не суперечать цьому датуванню й матеріали Дніпровського Правобережжя. Найбільш пізнім часом кінцем X - початком XI ст. - можна датувати парні захоронення Підгірцівського могильника та біля с. Судова Вишня ${ }^{85}$.

\section{Камери 3 гробовищами}

До першої групи камер-наслідувань віднесено 12 захоронень (додаток, № 24-35). Можна виділити два основні регіони їх поширення: Погориння (Старожуків, Білів, Пересопниця) та Київ із найближчою округою (Совки, Китаїв).

Розміри камер варіювались у межах 2,34×0,9-3 м, висота становила від 0,5 до 1,2 м. Вони мали прямокутну форму і були орієнтовані за віссю захід-схід. Вочевидь, переважна більшість споруд мала зрубну конструкцію. Стіни зводили 3 товстих дощок (Білів № 2, Китаїв-1 № 2/1973) (рис. 12, 3), тесаних

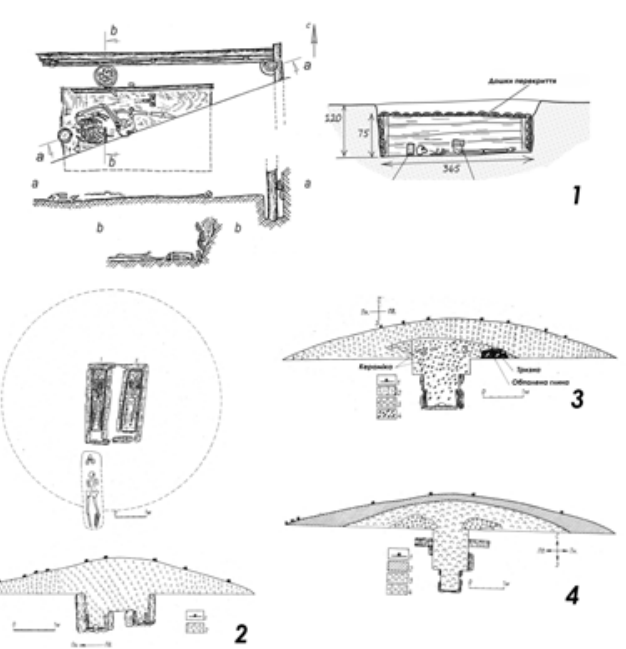


86 Мельник, Е. Н. Раскопки в земле лучан, 524.

87 Мовчан, I. I. (1993). Давньокиївська околиия. Київ: Наукова думка, 151. брусів (Старожуків-1 № 10) або цілих колод (Городище № 4, Білів № 36, Китаїв-1 № 1, 3/1973) (рис. 12, 2, 4). Зафіксовано приклади використання дуба, сосни. Гробниці Старожуківського і Пересопницього могильників (можливо, також Совки № 6) скріплювалися залізними цвяхами. Іншу - каркасно-стовпову - конструкцію мала київська камера 3 розкопок на пл. Калініна (Михайлівській). Споруда 3 горизонтальних дощок-горбилів, поставлених опуклою стороною всередину, закріплювалася за допомогою чотирьох кутових стовпів (рис. 12,1 ). Лише в одному випадку на дні камери також зберігся накат із брусів (Старожуків-1 № 10).

Зверху всі камери мали перекриття трохи більших розмірів. Як правило, його споруджували 3 товстих дощок, зрідка - $з$ обтесаних із зовнішнього боку (Городище № 4) або цілих (Китаїв-1 № 3/1973) колод. Іноді накат був обвугленим ззовні (Старожуків-1 № 10) чи зсередини (Білів № 2). В кургані № 4 біля c. Городище на перекритті було знайдено пташиний скелет.

3-поміж волинських камер із гробовищами лише у двох випадках (Старожуків-1 № 10, Білів № 36) перекриття було на рівні горизонту, тобто висота камери відповідала глибині могильної ями. Така конструкція $\epsilon$ характерною для переважної більшості давньоруських камерних гробниць. В одному похованні (Старожуків-2 № 12) накат влаштовано на 0,2-0,3 м вище. Перекриття решти камер було посередині могильної ями, на глибині 0,3-0,5 м від рівня давньої поверхні (а в пересопницькому кургані № 7, вочевидь, - іще глибше). Отже, загальна глибина могильних ям становила від 0,7 до 1,5 м. Про влаштування перекриттів у камерах Київщини висновувати важко через поганий стан збереженості або недоліки фіксування. Виняток становить поховання на пл. Калініна (Михайлівській), де дощатий накат зафіксовано на рівні давньої поверхні.

На дні камери завжди встановлювали дерев'яну труну, в яку поміщали тіла померлих. У білівському кургані № 2 на наявність труни вказує велика кількість залізних цвяхів, знайдених навколо скелета та між кісток, хоча, за припущенням К. М. Мельник, за допомогою цвяхів прикріпляли до дна могили тканину, якою був покритий труп ${ }^{86}$. У камері кургану № 10 зі Старожукова-1 зафіксовано залишки принаймні двох гробовищ, що відрізнялись за орієнтуванням. А в китаївському кургані № 1/1973 рештки двох небіжчиків у домовинах поміщено до окремих невеликих камер, на відстані 0,4 м одна від одної ${ }^{87}$. Гробовища сколочували з дощок; одного разу (Городище № 4) при зведенні поздовжніх стін використано товсті бруси. Ширина трун становила близько 0,5-0,6 м, довжина варіювалася від 
1,49 до 2,6 м. Як і самі камери, гробовища інколи обпалювали ззовні (Білів № 36) або зсередини (Старожуків-2 № 12).

Окрім згаданих комплексів зі Старожукова і Китаєва, усі кургани містили по одному похованню. Кістяки мали західне орієнтування, враховуючи сезонні відхилення на північ улітку (Старожуків-1 № 10) та на південь узимку (Городище № 4). Поховання здійснювали у випростаному стані на спині. В усіх захороненнях Києва та округи руки небіжчиків (або, принаймні, одну з них) було зігнуто в ліктях і покладено кистями в ділянки плечей, грудей, живота чи таза. Натомість, на Волині, як правило, ховали з простягнутими вздовж тіла кінцівками; випадки, коли одну з кистей рук клали на тазових кістках, зафіксовано лише двічі (Городище № 4, Білів № 2). В останньому 3 них, крім того, ноги були зігнуті в колінах у правий бік. Один із кістяків (Старожуків-1 № 10, поховання 2), очевидно, був обгорнутий берестою. За складом поховального інвентарю та, в одному випадку, антропологічними характеристиками можна виділити чотири чоловічі поховання (Старожуків-1 № 10, поховання 1; Київ, Михайлівська пл., Китаїв, № 2/1973, 3/1973) і чотири жіночі (Городище № 4, Старожуків-2 № 12, Білів № 2; Київ, № 12/1997; Китаїв-1 № 1/1973, поховання 2).

За кількістю інвентарю розглядувані захоронення різняться. У чотирьох комплек- сах знайдено лише по одному предмету. Біля трьох небіжчиків (Городище № 4; Старожуків-1 № 10, поховання 2, Совки № 6) інвентарю не виявлено взагалі. У двох камерах із Погориння (Старожуків-2 № 12, Білів № 2) знайдено по п'ять предметів. В останньому 3 них варто згадати знахідку золотої сережки біля нижньої щелепи померлого, яка, на нашу думку, являє собою «обол мертвих». Ще більше вирізняються обидва комплекси цього типу, розкопані в Києві. Жіноче поховання № 12/1997 містило вісім одиниць інвентарю, зокрема предмети імпорту та, ймовірно, залишки скрині з золотою фольгою, що наближує його до класичних камер. А частково пограбоване захоронення 3 розкопок на пл. Калініна належало воїну, про що свідчать знахідки бойової сокири, двох відер і залишків поясного набору. Деталі ремінної гарнітури було знайдено і в двох камерах із Китаєва. Ще одна ймовірна знахідка зброї - вістря списа або дротика (?) - походить із кургану № 10 Старожукова-1. Загалом же переважають досить прості прикраси (перстні, намистини, скроневі кільця, гудзики, фрагмент браслета) та побутові предмети (ніж, кресала, пінцет (?)).

На жаль, серед інвентарю слабо представлені вузько датовані речі. В межах XI ст. може бути датовано курган № 12 Старожукова-2, що містив золотоскляну та сердолікову намистини. Сокира 3 київського похо- 
88 Михайлов, К. А. Элитарный погребальный обряд, 149.

89 Івакін, Г. Ю., \& Козюба, В. К. Нові поховання X-XI ст., 38-39.

90 Самоквасов, Д. Я. (2016). Могильные древности северянской Черниговщины. Москва: Синодальная типография, 80, 86-87.

91 Приймак, В. В. (2018). Подковообразные фибулы из древнерусских памятников Левобережья Днепра. Filo Ariadne, 3. Retrieved from http://filoariadne. esrae.ru/pdf/2018/3/230.pdf.

92 Бліфельд, Д. І. Давньоруські пам'ятки, 179-180.

93 Михайлов, К. А. Элитарный погребальный обряд, 67.

94 Gräslund, A.-S. Birka IV, 40-41.

95 Соболев, В. Ю. Камеры, домовины, гробы, 67. вання на Михайлівській пл. може належати до типу III, який широко датують X-XI ст.; однак саме поховання перекривається валами «міста Володимира» ${ }^{88}$, отже, найімовірнішою датою його спорудження вбачають другу половину Х ст. Близьке датування має і поховання № 12/1997, прорізане більш пізнім захороненням XI ст. ${ }^{89}$

У Нижньому Подесенні можемо назвати принаймні чотири приклади камер із гробовищами, по одному із некрополів Шестовиці, Клонова, Седнева та Левінки. У двох останніх комплексах Д. Я. Самоквасов виявив підковоподібні фібули зі спіралеподібними закінченнями, які він прийняв за пряжки ${ }^{90}$. За висновками Ю. Ю. Моргунова та В. В. Приймака, подібні застібки почали надходити на територію Дніпровського Лівобережжя наприкінці X - на початку XI ст. ${ }^{91}$ За розмірами поховальних споруд - 2,1-3,5×1,6-1,7 м всі ці комплекси є досить близькими до своїх правобережних аналогів, поступаючись класичним камерам. Значно біднішим є і склад інвентарю: так, у шестовицькому кургані № 119 знайдено лише залізний ніж ${ }^{92}$. По дві камери з гробовищами другої половини Х ст. відомо на некрополях Гньоздова та Пскова ${ }^{93}$

Вочевидь, поховання цього типу є хронологічно пізнішими порівняно з класичними камерами і виникли уже на давньоруських (середньодніпровських - ?) теренах: як за- значає А.-С. Грьослунд, серед поховань Бірки поєднання дерев'яних обшивок могильних ям і гробовищ не трапляється ${ }^{94}$.

\section{Наземні склепи}

Наступна група поховальних споруд, представлена 15 комплексами, вирізняється розташуванням на рівні горизонту чи на підсипці, не властивим класичним камерам (додаток, № 36-50). Поширені вони в основному на Волині, між середніми течіями річок Стир і Горинь (Гірка Полонка, Теремно, Новосілки, Ставок, Старожуків, Білів, Пресопниця, Рогачів, Басів Кут). Поодинокі наземні склепи відомі також на некрополях літописних міст Пліснеська (Підгірці) та Icкоростеня (Коростень).

На могильниках Погориння (Старожуків, Білів, Пересопниця) наземні склепи та камери 3 гробовищами співіснували. Така сама ситуація спостерігається і на деяких некрополях XI-XII ст. у Новгородській землі (Рапті-Наволок, Верхнє Полужжя) ${ }^{95}$. Виникає спокуса пов'язати розміщення гробниць відносно денної поверхні з сезонністю: їх могли споруджувати на рівні горизонту о холодній порі року, через важкість земляних робіт. Із потеплінням досипали лише курганний насип. Справді, «зимове», південно-західне, орієнтування щодо «літнього», північно- 
західного, переважало (чотири випадки проти одного), проте такої вибірки явно замало для серйозних висновків.

Розміри гробниць становили 2-3,5×1,22,8 м, висота - від 0,4 до 1 м. У двох випадках (Гірка Полонка № 6, Старожуків-1 № 2) поховальні споруди мали дещо меншу ширину - 0,96 м і близько 0,8 м відповідно, проте з класичними камерами їх споріднює наявність елементів внутрішнього членування. У білівському кургані № 28 склеп був подвійним. Дно переважної частини склепів розміщувалося на рівні горизонту, лише у двох із них (Білів № 32, 35) - на підсипці заввишки близько 1 м.

Більшість поховальних споруд мала зрубну конструкцію. Двічі виявлено стовпи в кожному з кутів (Ставок № 2, Басів Кут № 7), проте спосіб кріплення стін залишився нез'ясованим. Стіни в трьох випадках заведено $з$ товстих дощок, у шести - 3 тесаних брусів, серед яких є дубові (Білів № 35) та соснові (Басів Кут № 7). Склепи мали дощате перекриття більшого розміру. У дев'яти випадках стіни та дах скріплювалися залізними цвяхами. Двічі (Білів № 32, Пересопниця № 29) зафіксовано залишки підлоги у вигляді дощатого накату. Іноді дно склепу (Пересопниця № 29), або - ще й перекриття (Басів Кут № 7), були вистелені березовою корою. Також зафіксовано пережитки обря- ду трупоспалення: посипання перекриття склепу золою з дрібним вугіллям (Новосілки № 2, Рогачів № 5, імовірно - Підгірці ВЗК № 2), шар золи по його внутрішніх стінках (Ставок № 2), зольна підсипка під дном склепу (Пересопниця № 29), купка вугілля на дні (Басів Кут № 7), вугілля в середніх шарах насипу (Старожуків-1 № 12).

Як і в похованнях попередньої групи, у більшості склепів збереглися залишки рухомих гробовищ, найчастіше - великих розмірів (1,8-2,2×0,6-0,94 м). У білівському кургані № 35 його було зведено 3 товстих брусів, а в решті випадків - $з$ дощок, переважно збитих залізними цвяхами. У трьох випадках на кришці гробовища та під його дном (Теремно № 1, Білів № 35) або тільки на кришці (Пересопниця № 29) виявлено зольні прошарки. В кургані № 7 із Басового Кута труну, як і сам склеп, було вистелено берестою ззовні та зсередини. У трьох склепах наявності труни не встановлено (Старожуків-1 № 12, Новосілки № 4, 2), хоча в останньому випадку її залишками може бути тонка дошка, виявлена під кістяком. Ще у двох захороненнях (Гірка Полонка № 6, Старожуків-1 № 2) функцію гробовища виконувало окреме членування, завширшки 0,5 і 0,4 м відповідно, відокремлене від решти внутрішнього простору камери дошкою-перегородкою. Припускаємо, що воно було накрите окремою кришкою. 

ке тиснения и перегородчатой эмали в древней Руси X-XII вв. Краткие сообщения Института истории материальной 范
96 Корзухина, Г. Ф. (1946). 0 техни-

У кожному зі склепів знайдено по одному кістяку, хоча за їх межами в курганах № 2 i № 12 могильника Старожуків-1 виявлено пізніші (?) захоронення. Усі поховання були орієнтовані на захід, враховуючи сезонні відхилення на південь (Підгірці ВЗК № 2, Новосілки № 2, Білів № 28, Пересопниця № 29) і північ (Басів Кут № 7). У семи випадках кінцівки були випростані. П'ять разів кисті обох рук (Старожуків-1 № 12, поховання 1; Білів № 28) або тільки лівої (Новосілки № 2, Пересопниця № 29, Рогачів № 5) покладено на таз чи поперек. У кургані № 32 із Білева права кисть лежала на грудях, ліва - на попереку. У склепі з Новосілок скелет виявлено 3 розведеними колінами. Двічі під кістяками фіксували підсипки з глини, золи та вугілля (Гірка Полонка № 6, Старожуків-1 № 2); в останньому випадку небіжчика, до того ж, було обгорнуто берестою. За складом інвентарю вдалося визначити, що чотири поховання належали чоловікам (Підгірці ВЗК № 2, Теремно № 1, Пересопниця № 29, Коростень № 5 поховання 1), три - жінкам (Гірка Полонка № 6, Білів № 35, Коростень № 5 поховання 2).

Безінвентарними виявились п'ять по97 Сергєєва, М. С. (2015). Майстри 3 обробки дерева та кістки давньоруського міста Воӥня. Київ; Харків: Майдан, 53 предмети, у трьох - по два, в одному - чотири, ще в одному - один. Абсолютно винятковим серед усіх квазікамерних поховань
Давньої Русі є пересопницький курган № 29, де було знайдено два десятки артефактів, зокрема ювелірні інструменти та поясний набір. У літературі комплекс отримав назву «поховання ювеліра» ${ }^{96}$. Вирізняються також два багаті воїнські захоронення, розташовані поза межами основного, волинського ареалу поширення наземних склепів (Підгірці ВЗК № 2, Коростень № 5), де знайдено по 12 предметів. Основними ж категоріями інвентарю, як і в похованнях попередньої групи, $\epsilon$ елементи одягу та прості прикраси (скроневі кільця, перстні, намистини, гудзики, фібула), а також - побутові предмети (ножі, оселки, гребінь, серп). Досить архаїчним обрядовим елементом $є$ поміщення до могили відер (Підгірці ВЗК № 2, Білів № 35, Пересопниця № 29, Басів Кут № 7, Коростень № 5). Згадані поховання з Підгірців і Коростеня містили залізні сокири; поодинокою $€$ знахідка списа (Теремно № 1). Крім того, 3 Підгірців походять предмети особистого благочестя - бронзовий енколпіон і срібний хрест. Більшість матеріалу має доволі широке датування. Однобічні гребінки, одну 3 яких знайдено в кургані № 32 з Білева, на території Русі датують X-XI ст., хоча більша ïx частина $\epsilon$ не пізнішою за початок XI ст. ${ }^{97}$ Кінцем X - початком XII ст. датують S-подібні скроневі кільця (Підгірці ВЗК № 2, Гірка
Полонка № 6). Виті перстні (Теремно № 1) 
98 Седова, М. В. (1981). Ювелирные изделия древнего Новгорода (X-XV вв.). Москва: Наука, 125.

99 Liwoch, R. Zabytki z wykopalisk Teodora Nieczuja-Ziemięckiego, 41.

100 Корзухина, Г. Ф. О технике тиснения, 46-48.

101 Авласович, А. М. (2015). Исследование сидячего погребения радимичанки в курганном некрополе у д. Студёнка Быховского района. В Быховские краеведческие чтения. IV научнопрактическая конференция, посвященная 100-летию со дня начала Первой мировой войны, 30 декабря 2014 г., г. Быхов (с. 56, 59). Быхов: [6. в.].

102 Войтехович, А. В. Погребальный обряд, 42.

103 Плавинский, Н. А. (2014). Некоторые результаты раскопок средневековых погребальных памятников Браславского Поозерья археологической экспедицией Национального исторического музея Республики Беларусь. В Vēsture: avoti un cilvēki (c. 306-307). Daugavpils: Daugavpils Universitātes Akadēmiskais apgāds "Saule".

104 Соболев, В. Ю. Камеры, домовины, гробы, 67. 3'являються на початку XI ст. і побутують упродовж усієї домонгольської доби ${ }^{98}$. «Великий здвоєний курган» із Підгірців за сукупністю речей датують кінцем $\mathrm{X}$ - першою чвертю XI ст. ${ }^{99}$ Нарешті, зі згаданого пересопницького поховання походять єдині нин відомі штампи для виготовлення лопатевих намистин, побутування котрих обмежується другою половиною X - початком XI ст. ${ }^{100}$

Наземні склепи демонструють яскравий приклад локальної (переважно - волинської) поховальної традиції: у Середньому Подніпров'ї та на Дніпровському Лівобережжі захоронення такого типу авторові не відомі. Синхронні рядові трупопокладення на рівні давньої поверхні або на підсипці дуже поширені в розглядуваному регіоні.

Така концентрація поховань у наземних дерев'яних зрубах спостерігається в Могильовському Подніпров'ї та Посожжі, де вони супроводжуються типовим для радимичів поховальним інвентарем, їх датують у межах XI ст. ${ }^{101}$ А найбільш ранньою подібною пам'яткою на території Білорусі $\epsilon$ парне поховання могильника Погоща у Браславському Поозер'і, яке А. В. Войтехович називає «наземною камерою» ${ }^{102}$. Воно містило рештки зрубної конструкції розмірами $3 \times 3$ м; було знайдено предмети озброєння та набір торговельного інвентарю. Функціонування могильника належить до друго половини X - першої половини XI ст., а ймовірніше - до кінця X - початку XI ст. ${ }^{103}$ Ще пізніше - другою половиною XI - першою половиною XII ст. - поховання, здійснені в наземних дерев'яних конструкціях, за розмірами порівнянних із камерами, датують на території Новгородської землі. В. Ю. Соболєв характеризував їх як прояви реалізації північноєвропейської поховальної традиції «на місцях» ${ }^{104}$.

\section{Земляні камери}

Виділення поховальних комплексів цієї групи є найбільш проблематичним, оскільки даних про параметри могильних ям щодо багатьох комплексів немає. До типових земляних камер належить захоронення по вул. Великій Житомирській у Києві. Більш-менш упевнено можна віднести до них поховання у курганах № 1 і 21 Білівського могильника. В обох випадках труну було встановлено «на розчищеному підгрунті» (материку), отже, площа могильних ям значно перевищувала розміри гробовищ. У кургані № 3 біля с. Новосілки два поховання, у труні та без, було здійснено в одній ямі, під спільним перекриттям. Також до земляних камер можна віднести чотири поховання з дерев' яними перекриттями значних розмірів, шо були на певній висоті від домовин, забезпечуючи вільний простір усередині могильних ям. Загалом до цієї гру- 
пи ми віднесли вісім захоронень (додаток, № 50-58).

Перекриття споруджували на рівні горизонту (чотири випадки) або в середній частині могильної ями, на глибині $0,3-0,65$ м. Загальна глибина могильної ями при цьому могла сягати 1,35 м. У похованні по вул. Великій Житомирській яма у перетині мала подвійний, східчастий профіль: усередину більшої ями розмірами $3,33 \times 1,24 \mathrm{м}$ було впущено власне земляну камеру $(2,24 \times 0,9 \times 0,73$ м). Двічі зафіксовано розміри перекриття, досить значні: $3,1 \times 2,4$ м і $3,12 \times 1,8$ м. У білівському кургані № 21 перекриття було споруджене зі складених навхрест у два ряди обтесаних брусів, у кургані № 1 з Городська - з обгорнутих берестою широких дубових брусів, а в згаданому київському похованні - 317 колод діаметром 0,1-0,15 м. Перекриття решти земляних камер являло собою дощатий поміст. Іноді його фіксували обвугленим згори (Білів № 12) або знизу (Білів № 1).

У середній частині насипу кургану № 2 біля с. Гірка Полонка виявлено сліди тризни - пласт зотлілого дерева та багато фрагментів кераміки.

Розміри гробовищ відрізнялись: 2-2,5×0,45-0,9 м. Порівну представлені домовини, споруджені 3 дощок і $з$ товстих дубових брусів. Принаймні в половині випадків при цьому використано залізні цвяхи. Двічі (Білів № 21, 22) під гробовищами фіксували зольну підсипку. Лише стосовно кургану з Городська про залишки труни не повідомляється.

Усі кургани, за винятком одного (Новосілки № 3) містили по одному похованню, не враховуючи впускних. Кістяки знайдено у випростаному стані, головою на захід; у двох випадках зауважено сезонні відхилення на південь (Гірка Полонка № 2, Білів № 1). У похованні 2 кургану № 3 із Новосілок визначено східне орієнтування, проте інші дані цьому дещо суперечать. Руки здебільшого випростано вздовж тіла, тільки в двох випадках одну (Новосілки № 3) або обидві (Білів № 12) руки покладено в ділянці таза. За характером інвентарю три поховання можна визначити як жіночі (Білів № 12, Новосілки № 3, поховання 1, Київ б/№ 2002).

Біля п'яти кістяків інвентарю не виявлено. У кургані № 12 з Білева та кургані № 33 Новосілок (поховання 1) знайдено по одному S-подібному скроневому кільцю кінця X початку XII ст. Найчисленніший інвентар містили білівський курган № 21 та київське поховання 1984 р. по вул. Великій Житомирській, 2. У першому було знайдено п'ять залізних предметів, зокрема дві підковоподібні 

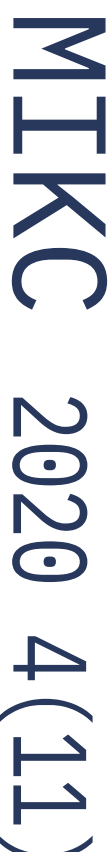

5 Михайлов, К. А. Элитарный погребальный обряд, 60-61.

106 Бліфельд, Д. І. Давньоруські пам'ятки, 137.

107 Там само, 150-151.

108 Войтехович, А. В. Погребальный обряд, 33

109 Зозуля, С. С. (2012). Датировка камерного погребения в кургане 348 Тимеревского могильника. Российская археология, 4, 97; Зозуля, С. С.

(2014). К вопросу об особенностях камерного обряда погребения в Ярославском Поволжье. Погребения в курганах 100 и 459 Тимерёвского археологического комплекса. В XIV Tuхомировские краеведческие чтения: Материалы научной конферениии (с. 235). Ярославль: Ярославский государственный историко-архитектурный и художественный музей-заповедник . фібули X-XI ст. та залишки відра; у другому - набір жіночих прикрас, зокрема срібні з позолотою лунниці.

Земляні камери подекуди трапляються на суміжних територіях. На теренах Дніпровського Лівобережжя К. О. Михайлов виділив два подібні комплекси - шестовицький курган № 61/1 та чернігівське поховання № 29/1989 ${ }^{105}$, хоча в останньому випадку дерев'яні конструкції стін, вочевидь, просто не збереглись. Сюди ж можемо віднести курган № 41 з Шестовиці ${ }^{106}$. Земляні камери Лівобережжя яскраво демонструють вплив християнства: як і на Волині, небіжчиків покладено до гробовищ, а в шестовицькому кургані № 61/1 знайдено візантійський перстень-печатку з зображенням Христа ${ }^{107}$.

На могильнику Погоща відомо три поховання в ямах великих розмірів із дерев'яним перекриттям угорі, проте без внутрішніх конструкцій. Усі вони належали чоловікам і містили предмети озброєння, датовані кінцем X - першою половиною ХІ ст. ${ }^{108}$ Земляні камери Північної Русі також, як правило, пізніші, ніж класичні. С. С. Зозуля датує таке поховання 3 кургану № 348 Тімерьовського могильника 990-1010-ми рр., а поховання № 100 має близьке датування за молодшою монетою 977 p. ${ }^{109}$

\section{Висновки. Деякі спостереження щодо трансформування елітарних інгумаційних поховань протягом X-XI ст. Камерні та квазікамерні поховання в етносоціальних реконструкціях}

Аналіз конструктивно-ритуальних елементів класичних камерних поховань Середнього Подніпров'я переконливо свідчить про їх спорідненість із подібними пам'ятками Скандинавського регіону та Північної Русі. Як і на півночі Європи, тут співіснували камери зрубної та каркасно-стовпової конструкції, що імітували житлові споруди відповідних типів. Разом із тим, у Києві камерний обряд поступово набув деяких специфічних рис, таких як рубка стін гробниць «в обло», перекриття у вигляді накату з колод і положення кінських тіл паралельно людським.

Зведення класичних камерних гробниць припиняється наприкінці X ст. У Швеції цей процес пов'язаний зі згасанням провідних торгових центрів, у Данії та на Русі - 3 насадженням християнської ідеології. Найбільш пізні давньоруські камери (Тімерьово, 


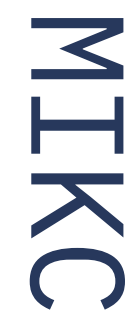

$\underset{0}{\infty}$

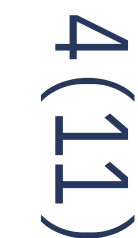

110 Сытый, ю. Н. (2011). Могилы христиан Чернигова $X$ века (к постановке проблемы). В Християнізаційні впливи в Київській Pусі за часів князя Оскольда: 1150 років. Матеріали міжнародноі наукової конферениї̈, 19-20 листопада 2010 р. (с. 100-101). Чернігів; Луцьк: Терен; Ивакин, В. Г. Киевские погребения X века, 13
Удрай) розташовані в периферійних регіонах Київської держави і датовані кінцем X - початком XI ст. В цей самий період камерний обряд 3'являється на Прикарпатті (Судова Вишня, Підгірці), вже після свого згасання в Києві. Однак повністю відмовитись від цієї традиції давньоруська еліта змогла не відразу. Принаймні в останній чверті X ст. з'являється низка різновидів морфологічно подібних поховальних споруд: камери 3 гробовищем, земляні камери, великі могильні ями та дерев'яні склепи на рівні горизонту. Їх можна об'єднати під терміном «квазікамери», або «камери-наслідування». Між камерними гробницями та їх наслідуванням спостерігається спадкоємність, проте через докорінні відмінності в сутності обряду потрібно розглядати обидві групи пам'яток як окремі явища. Очевидно, в умовах християнської доктрини панівні кола давньоруського суспільства прагнули поєднати традиційні звичаї елітарних поховань із новими канонами. Така картина є характерною і для північноєвропейських могильників.

Попри незначну кількість вузько датованих комплексів, безсумнівним видається поетапне «проникнення» обряду поховання у камерах-наслідуваннях із Києва до округи і далі на захід, від ключових населених пунктів до більш віддалених. При цьому, незважаючи на поодинокі винятки, простежується чітка генеральна тенденція до поступового спрощення як конструкції поховальних споруд, так і інвентарного набору.

Початок масового поширення псевдокамер на території Волині, безперечно, слід пов'язувати 3 державницькою діяльністю Володимира Святославича, котра могла супроводжуватись притоком населення («ліпших мужів») із Подніпров'я. Прикметно, що жодного класичного камерного поховання в межах регіону виявлено не було.

Абсолютна більшість камер-наслідувань (можливо, за винятком деяких наземних склепів) містила гробовища, що саме по собі $€$ індикатором християнського поховального обряду чи, принаймні, його впливу ${ }^{110}$. Ця конструктивно-ритуальна особливість рішуче суперечить властивій класичним камерам ідеї будинку, в якому «оселявся» небіжчик після смерті. Разом із тим, квазікамери все ще демонструють численні риси язичницької поховальної традиції: наявність досить численного (хоча й не сумірного $з$ класичними камерами) поховального інвентарю; обрядові дії, пов'язані з вогнем; неканонічне положення кінцівок у більшості небіжчиків.

Цілком очевидно та природно, що на Волині пам'ятки цієї категорії побутували довше, ніж у Середньому Подніпров” чим і пояснюється куди більша їх кількість. Утім, навряд чи їх датування виходило за 
111 Мельник, Е. Н. Раскопки в земле лучан, 552-553, 556, 561, 563, 573574,575

112 Мельникова, Е. А., \& Петрухин, В. Я (1986). Формирование сети раннегородских центров и становление государства (Древняя Русь и Скандинавия). История СССР $, 5,73$.

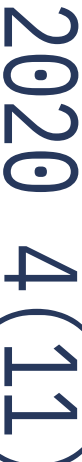

113 Кирпичников, А. Н., Лебедев, Г. С., Булкин, В. А., Дубов, И. В., \& Назаренко, В. А. (1980). Русско-скандинавские связи эпохи образования Киевского государства на современном этапе археологического изучения. Краткие сообщения Института археологии АН СССР, 160, 31.

114 Gräslund, A.-S. Birka IV, 79-82; Жарнов, Ю. Э. Женские скандинавские погребения, 117-188.

115 Соболев, В. Ю. (1997а). Камерное захоронение в могильнике Рапти-Наволок II в контексте становления древнерусского погребального обряда.

В XIII конферениия по изучению истории, экономики, литературы и языка скандинавских стран и финляндии. Тезисы докладов (с. 185). Петрозаводск; Соболев, В. Ю. (1997b). 0 древнерусских камерных погребениях Новгородской земли. В Памятники старины. Кониееции. Открытия. Версии. Памяти В. Д. Белеикого (Т. II, с. 277). Санкт-Петербург; Псков: Невельская типография. межі кінця $\mathrm{X}$ - першої половини XI ст. Серед камер-наслідувань найбільш спрощеною формою обряду вирізняються земляні, що проявляється як у їх конструкції, так і в кількості поховального інвентарю. Подальшу лінію розвитку досліджуваних пам'яток на території Волині, очевидно, презентують поховання, в яких домовину безпосередньо накривав поміст більших (іноді - значно більших) розмірів. Подібні споруди могли бути розміщені як на рівні горизонту (Ставок № 1, Крупа № 4), так і в могильній ям (Лище-2 № 7, Гірка Полонка № 1, 2, Новосілки № 1, Вечулки № 1, 3, Ставок № 4) ${ }^{111}$

Щодо безпосередньої спадковості між обома формами обряду, розглядуваними в статті, немає жодного сумніву. Зокрема, у Підгірцях одна $з$ камерних гробниць та наземний склеп були споруджені під курганними насипами, що змикалися («Великий здвоєний курган»), що свідчить не лише про їх хронологічну близькість, а й про можливі родинні зв'язки між похованими. Переходячи до реконструкцій соціального характеру, потрібно поставити питання так: чи є обряд поховання у квазікамерах індикатором високого соціального статусу померлих; чи $\epsilon$ описаний набір ритуальних дій показником належності похованого до давньоруської еліти? Під цим розмитим поняттям розуміємо коло людей, які були задіяні у державотвор- чому процесі, професійній військовій справі, міжнародній торгівлі тощо.

Досить усталений у літературі 19701980-х рр. погляд на похованих у класичних камерах як на представників дружинної верхівки, переважно - скандинавського походження, що перебували на службі у давньоруських (або конкретно київських ${ }^{112}$ ) князів ${ }^{113}$, було суттєво скориговано. Нині їх соціальний склад зазвичай цілком слушно реконструюють більш широко: як коло заможних варягів - воїнів і купців - та представників їхніх родин ${ }^{114}$. Деякі поховані в київських камерах брали безпосередню участь у бойових діях, імовірним прикладом чого можуть слугувати київські поховання 105 і 106, про що було сказано вище. Не $є$ поодинокими знахідки торговельного інвентарю. А численні жіночі та дитячі поховання радше репрезентують належність до певної касти, ніж соціальний статус самого небіжчика чи небіжчиці.

За В. Ю. Соболєвим, усі північноруські «камери» (власне, псевдокамери) ХІ ст., пов'язані зі становленням нової давньоруської еліти - представників князівської адміністрації та їхніх найближчих родичів - вочевидь, немісцевого походження 115 Соціальний склад похованих у квазікамеpax Дніпровського Правобережжя не був однорідним. Захоронення у кургані № 29 iз 
116 Корзухина, Г. Ф. О технике тиснения, 45 .

117 Соболев, В. Ю. Камеры, домовины, гробы, 67.
Пересопниці належало заможному ремісникові-ювеліру ${ }^{116}$. П'ять захоронень містили предмети озброєння, що є доволі рідкісним для південноруських поховальних комплексів кінця X-XI ст. Ще у двох захороненнях виявлено поясні набори, причому обидва кістяки мали сліди бойових поранень. У низці поховань знайдено досить коштовні речі: невеликі золоті прикраси, предмети імпорту, фібули, відра. Проте подекуди подібні предмети трапляються і в інших синхронних інгумаціях. В основній же масі інвентар камер-наслідувань представлений цілком рядовими і нечисленними речами, або ж його взагалі немає.

У межах усіх десяти волинських могильників, де відомі квазікамери, найбільші кургани містили саме такі поховання. Водночас, у половині випадків аналогічні обрядові форми трапляються у курганах невеликого чи середнього розміру. При цьому, параметри курганного насипу чи поховальної камери жодним чином не корелюються з багатством інвентарю. Наведені факти підводять до висновку, що обряд поховання у квазікамерах на Волині (на відміну від Середнього Подніпров’я чи Підгірцівського могильника) не є прямим продовженням камерного і не може бути однозначно пов'язаний із представниками давньоруської еліти. Радше ми маємо справу 3 імітацією престижного поховального ритуалу більш раннього часу. За влучним висловом того ж В. Ю. Соболєва, в середовищі населення Новгородської землі другої половини XI ст. збереглись лише загальні уявлення про камери, а конкретні способи і прийоми їх спорудження були індивідуальними ${ }^{117}$.

Отримані результати доводять доцільність виділення камер-наслідувань в окрему категорію ранньосередньовічних поховальних пам'яток. Подальші розробки в цьому напрямі мають доповнити реконструйоване бачення релігійного, соціального та політичного поступу населення південноруських земель на етапі формування державності.

\section{Каталог квазікамерних поховань із території Дніпровського Правобережжя 1. «Класичні» камерні поховання}

1. Судова Вишня, поховання 1962 р. Простежено слабкі залишки курганного насипу. Частково зруйноване поховання було здійснене в могильній ямі $(2 \times 1,5 \times 0,6-0,7$ м), орієнтованій за віссю захід-схід, зі шматками зотлілого дерева по краях. Кістяк жінки 45-50 років лежав головою на захід, руки випростано вздовж тіла. Інвентар: обабіч голови - по одному фрагментованому скроневому кільцю київського типу; біля нижньої щелепи та на грудях - намисто (3 великі 

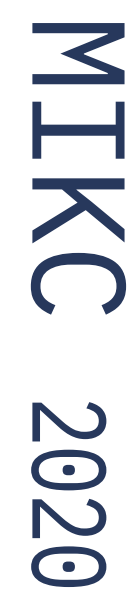

118 Ратич, 0. 0. Багате поховання рубежу X-XI ст. , 162-168.

119 Ливох, Р. Большие курганы, 486-488; Liwoch, R. Zabytki z wykopalisk Teodora Nieczuja-Ziemięckiego, 24-29, $70-75$.

120 Ливох, Р. Большие курганы, 488-489; Liwoch, R. Zabytki z wykopalisk Teodora Nieczuja-Ziemięckiego, 31-39, 77-85. срібні намистини, 7 срібних серцеподібних підвісок, 1 бронзова підвіска (?), 19 скляних пронизок, 8 бурштинових і 8 пастових намистин, 10 мушель 3 отворами); ближче до поперека - бубонець і 5 суцільних гудзиків; на лівій руці - срібний витий браслет срібний перстень із бурштиновою вставкою; на животі - 16 срібних округлих бляшок; у ногах - 28 серцеподібних і 5 округлих бронзових бляшок; у заповненні - срібний кубикоподібний предмет (важок - ?), по дві намистини зі скла та гірського кришталю ${ }^{118}$.

2. Підгірці, «великий курган на селянській ділянці». $\mathrm{h}=2,5$ м. На глибині 3 м від вершини знайдено скелети чоловіка та жінки на спині, з'єднані кистями, головами на захід. Навколо виявлено численні залізні цвяхи та сліди дерева (рис. 8, 1). Інвентар: праворуч від чоловічого кістяка - меч типу $\mathrm{S}$ із залишками піхов із дерева та шкіри, залізний ключ (?), ліроподібна пряжка, залишки 2 відер, оселок і кістяна оправа (колодка ножа - ?); на грудях - залишки кольчуги; у ділянці поперека - 2 бронзові поясні кільця у роті - золота бляшка («обол мертвих»); на правій руці жіночого кістяка - золотий пластинчатий браслет; поруч із кістяком - 4 сердолікові намистини та глиняна посудина ${ }^{119}$.

3. Підгірці, «великий здвоєний курган» № $1 . \mathrm{h} \approx 2 \mathrm{м}, \varnothing \approx 16$ м. На глибині 1,7 м виявлено шар деревного вугілля, а нижче за- фіксовано прямокутник із гнилих дощок (залишки перекриття). Всередині гробниця мала дерев'яну оббивку, від якої залишилися чорні смуги по краях. На глибині 2,75 м виявлено два кістяки зі схрещеними руками, головами на захід (рис. 8, 2). Інвентар: праворуч від чоловічого скелета - меч типу $\mathrm{V}$ із бронзовою бутероллю, залізна сокира-чекан, розімкнутий срібний гранований браслет, залишки 2 відер, срібні поясні накладка і наконечник, 3 ножі (один - зі срібною обмоткою) та уламок скляного предмета; на правій ключиці - срібний хрест скандинавського типу; на пальцях обох рук - по одному золотому пластинчатому персню; ліворуч від жіночого черепа - срібний хрест скандинавського типу; на пальці правої руки - срібний перстень із напівсферичним щитком-брязкальцем; на пальцях лівої руки - два срібні пластинчаті персні; ліворуч від скелета - скроневі кільця (в т. ч. - срібні S-подібні), кілька намистин із сердоліку, гірського кришталю та скла, бронзова ажурна підвіска, залізний ніж, глиняне пряслице, дерев'яна чаша, 2 вепрячі ікла; в ротах обох скелетів - по золотій бляшці («оболи мертвих») ${ }^{120}$.

4. Підгірці, курган б/№ 3 розкопок Я. I. Пастернака. $\mathrm{h}=12$ м, Ø $=14$ м. У пошкодженому грабіжницькою траншеєю насипі виявлено перевідкладені людські кістки та залишки яєчної шкаралупи. Могильна яма 
121 Пастернак, Я. Літописний город Пліснеськ, 146.

122 Тут і далі нумерація за: Каргер, М. К. Древний Киев.

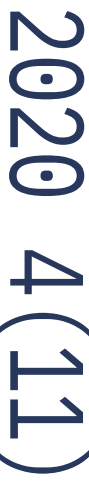

123 Хойновский, И. А. Раскопки великокняжеского двора, 40-41; Каргер, М. К. Древний Киев, 167-168.

124 Хойновский, И. А. Раскопки великокняжеского двора, 28-29, табл. I, рис. 2; Каргер, М. К. Древний Киев, 167-168.

125 Гезе, В. (1905). Заметки о некоторых киевских древностях. Записки отделения русской и славянской археологии Русского археологического общества, 7 (1), 143-146: Каргер, М. К. Древний Киев, 169-172.

126 Вельмин, С. П. Археологические изыскания, 144; Oтчет Императорской археологической комиссии за 1908 г. (1912). Санкт-Петербург, 152-153; Каргер, М. К. Древний Киев, 172-174; Ивакин, Г. Ю., Иоаннисян, 0. М., \& Елшин, Д. Д. (2010). Архитектурно-археологические исследования, 384-386; Івакін, Г. Ю., Іоаннісян, 0. М., Йолшин, Д. Д., \& Лукомський, Ю. В. Дослідження Десятинної церкви, 134; Хамайко, Н. Камерні поховання, 138-143.
$(2,5 \times 2,4 \times 1,3$ м) містила всередині дерев'яний зруб із підлогою та заваленим перекриттям. Інвентар: залізне вістря стріли і залізний виріб у вигляді клевця ${ }^{121}$.

5. Київ-I, поховання $105^{122}$. Здійснене у зрубі $(\approx 2,8 \times 2,1 \mathrm{м})$, перекритому дубовим накатом, що провалився на дно камери. На дні, викладеному дошками, - кістяк, орієнтований головою на північний схід. Інвентар: залізний меч, вістря списа, зотлілий лук i близько 50 вістер стріл, що були в колчані $з$ лубу, обтягнутому шкірою та прикрашеному прямокутними кістяними бляшками, зотлілий ремінь із пряжкою і наконечником ${ }^{123}$.

6. Київ-I, поховання 106. У могильній ямі завглибшки $\approx 2,8$ м від сучасної денної поверхні виявлено скелети людини (головою на схід) і коня з підігнутими ногами (напевно, з таким самим орієнтуванням). Інвентар: гривня з витого срібного дроту на шиї, залізне вістря стріли, ікло вепра, амфора і миска ${ }^{124}$.

7. Київ, поховання 108. Під час земляних робіт на глибині близько 2 м виявлено кістки людини і коня. Інвентар: меч, кинджал iз кістяним руків'ям, бойова сокира-чекан, близько 40 дирхемів (у т. ч. - Ісмаїла ібн Ахмеда 287/900р.), близько 40 срібних бляшок серцеподібної, овальної та квадратної форми, понад десять скляних гральних фішок, гральна кістка у формі паралелепіпеда, два мідні бубонці, залізні стремена та вудила; М. К. Каргер відносив до цього поховання і скандинавську кільцеподібну фібулу 3 довгою голкою, а за деякими даними, кістяк був знайдений «у шоломі та панцирі» ${ }^{125}$.

8. Київ-1, поховання 109. На глибині близько 1,7 м від рівня давньої поверхні зафіксовано зруб із соснових колод, споруджений «в обло». Розміри об'єкта $-5,5 \times 5,5$ м (за матеріалами розкопок 2008-2009 pp. $5,8 \times 5$ м; розміри котловану - $>6,4 \times 6,3$ м), стінки збереглися на висоту до трьох вінець. На загальному плані розкопу Д. В. Мілєєва паралельно південній стінці позначено колоду, врубану в західну стінку. Повторні розкопки підтвердили наявність додаткової лаги в 1,1 м від південної стінки. На момент розбирання зрубу його внутрішній простір не був заповнений землею. Крім того, в недокопаній Д. В. Мілєєвим частині вперше виявлено фрагменти кісток двох особин коня та, за інформацією О. В. Комара й Н. В. Хамайко, фрагмент черепа людини (рис. 10, 1). Інвентар: бронзовий ремінний наконечник, бронзова ремінна накладка, аморфні залізні предмети; за даними С. Вельміна - два дирхеми; 3 повторних розкопок - половинка дирхема початку X ст. із графіто у вигляді подвійного хреста попід північною стінкою ${ }^{126}$.

9. Київ-I, поховання 110. Поховальна споруда у вигляді зрубу $(3 \times 2 \times 1,15$ м) мала 
127 Вельмин, С. П. Археологические изыскания, 138; Известия Императорской археологической комиссии ИАК за 1908 г. Известия Императорской археологической комиссии. (1909). Прибавления к Вып. 32, 128-129; Каргер, М. К. Древний Киев, 175-176; Михайлов, К. А. Элитарный погребальный обряд, 204.

128 Каргер, М. К. Древний Киев, 178-182. дощату підлогу. Стіни з колод збереглися на висоту дев'яти вінець. Серед матеріалів розкопок збереглось багато залізних цвяхів, на думку М. К. Каргера, пов'язаних із влаштуванням дерев'яного перекриття (про «завалену стелю» писали і в київській пресі). На дні камери лежав кістяк хлопчика-підлітка головою на північний захід (на думку К. О. Михайлова, в сидячому положенні). Інвентар: на грудях - два срібні дирхеми-підвіски (299/911-912 р.; на одному було продряпано хрест із трьома поперечинами) та хрестоподібна накладка; у ногах - залізні обручі від двох відер; ліворуч від кістяка, попід стінкою камери, - три глиняні горщики, в одному 3 яких - кістяна ложка 3 плетеним орнаментом і кільцем для підвішування; ліворуч від скелета - набір із 157 астрагалів для гри в бабки (на деяких продряпано орнамент, а деякі залиті свинцем); у заповненні - залізний ніж із кістяною колодкою, бронзова підковоподібна фібула, мініатюрна залізна сокирка, два мініатюрні оселки, бронзове коромисло від терезів, два срібні гудзики, фрагмент кістяного гребеня, кістяна «свистулька» (юрок ?), інші кістяні предмети, три просвердлені вепрячі ікла, багато раковин ипіо з отворами для підвішування ${ }^{127}$.

10. Київ-I, поховання 112. Поховання здійснене в могильній ямі $(3,5 \times 3,3$ м), виритій на глибину 3,75 м від сучасної денної поверхні. По иї стінках добре помітні відбитки зрубу та зотлілі шматки дерева. По верхніх краях ями збереглись сліди перекриття 3 колод. На дні ями виявлено залишки чоловічого та жіночого кістяків поганої збереженості, головами на захід, а в 0,75 м від них, у північно-західному куті ями, - череп і шийні хребці коня. Поховання було пограбоване (рис. 10, 1). Інвентар: залишки залізної оковки щита; срібна кільцеподібна фібула з довгою голкою, намисто 3 восьми сердолікових намистин (сім 14-гранних і одна циліндрична) і восьми дирхемів (287/900901 - 310/922-923 рр.), три скроневі кільця волинського типу, срібний щитковий перстень, мініатюрний бронзовий ключик, дві перлини 128 .

11. Київ-I, поховання 113. Під субструкціями фундаментів Десятинної церкви виявлено залишки зрубної гробниці, спорудженої «в обло», південно-західну частину якою зруйновано фундаментами «нового» храму XIX ст. Довжина споруди з заходу на схід понад 2,8 м, 3 півночі на південь - 2,6 м; глибина становила не менше ніж 1,4 м. Перекриття камери було складене 3 тонких колод у два перпендикулярні один одному ряди. В заповненні виявлено три залізні цвяхи Уздовж південної стінки зрубу на дерев'яній підлозі лежав частково порушений кістяк східного орієнтування. В її західній частині, 
129 Каргер, М. К. (1940). Погребение киевского дружинника X в. Краткие сообщения Института истории материальной культуры АН СССР, $V, 79-82$; Каргер, М. К. Древний Киев, 182-185.

130 Каргер, М. К. Киевская экспедиция, 39; Каргер, М. К. Древний Киев, 185187.

131 Каргер, М. К. Древний Киев, 189-190; Зоценко, В. Н. Киевский некрополь II, 464.

132 Антонович, В. Б. Археологические находки, 252-253; Антонович, В. Б. 0 древнем кладбище, 43; Каргер, М. К. Древний Киев, 190-191; Андрощук, Ф. Скандинавские древности, 39-40; Зоценко, В. Н. Киевский некрополь II, 464-466. на думку М. К. Каргера, могло бути захоронення коня, на що вказує повний асортимент збруї (рис. 10, 3). Інвентар: ліворуч від кістяка - бойова сокира та вістря списа; в північно-східному куті камери - залишки великого колчана 3 понад двадцятьма стрілами, вудила, пара стремен і залишки кінської збруї (шматки шкіряних ременів із прикріпленими до них сімома бронзовими серцеподібними бляшками, однією срібною прорізною бляшкою і чотирма залізними пряжками); в центрі камери - обручі та дужка від відра ${ }^{129}$.

12. Київ-I, поховання 114. Під долівкою житла XIII ст., на глибині 2,25 м від сучасної денної поверхні, виявлено могильну яму $(3 \times 1,7$ м $)$ із залишками дерева вздовж стінок По кутах зафіксовано три ямки від стовпів діаметром 0,15-0,2 м, глибиною 0,45-0,5 м, що звужувалися донизу. Простежено залишки перекриття 3 перехрещених колод. На дні камери виявлено скелет чоловіка, а по ліву руку від нього - погано збережений жіночий кістяк. Орієнтовані головами на захід (рис. 9, 2). Інвентар: біля правого стегна чоловічого кістяка - меч і ще один залізний предмет; біля його лівого плеча - фрагменти залізної оковки колчана 3 близько двадцятьма вістрями стріл; на грудях - три бронзові гудзики ${ }^{130}$.

13. Київ-II, поховання 116. У грунтовій могилі було виявлено кістяк і довгий двосто- ронній меч. За даними кореспонденції, тут само знайдено і супровідне захоронення коня. Інвентар: меч із рукояттю, прикрашеною сріблом, кільцева фібула із довгою голкою; за рукописними свідченнями В. Б. Антоновича, кольчуга, шолом, точильний камінь, сережки з золотого та срібного дроту 3 намистинами, східна монета-підвіска ${ }^{131}$.

14. Київ-II, поховання 117. На думку Ф. А. Андрощука і В. М. Зоценка, становило єдиний комплекс із похованням 125 У грунтовій могилі знайдено кістяки людини і коня, голову якого було проломлено великим каменем, знайденим у черепі. Інвентар: франкський меч, залізна сокира, вістря списа, 8 вістер стріл, фрагмент залізного шолома, 2 залізні стремені, бронзова зі срібною інкрустацією поясна пряжка; за даними однієї з праць В. Б. Антоновича, кольчуга ${ }^{132}$.

15. Київ-I, поховання 123. На глибині 2,65 м від рівня сучасної поверхні виявлено залишки дерев'яного зрубу $(2,5 \times 1$ м), що зберігся на висоту 0,25-0,3 м. Стінки споруджено «в лапу» 3 тонких (діаметром 0,1 м) колод і додатково скріплено залізними цвяхами. Зверху споруда перекривалася накатом iз таких самих колод. Кістяк із випростаними кінцівками був орієнтований головою на південь (рис. 11, 1). Інвентар: на черепі - залишки золототканої парчі; обабіч черепа по два скроневі кільця із золотого дроту; біля 
133 Копилов, Ф. Б. (1951). Зрубне поховання біля Десятинної церкви. Археологія, V, 233-235; Каргер, М. К. Древний Киев, 207-208.

134 Килиевич, С. Р. Исследования на территории, 286; Килиевич, С. Р. Детинец Киева, 151-152.

135 Стосовно обох камерних поховань 1988 р. нумерацію подано за звітною документацією: Боровский, Я. Е. Архипова, Е. И., Калюк, А. П., \& Сыромятников, А. К. (1988). Археологические исследования в «Верхнем Киеве» в 1988 г. (Отчет о раскопках по ул. Б. Житомирской, 2 и наблюдениях за земляными работами в «Верхнем городе» в 1988 г. Науковий архів Iнституту археологї̈, ф. е., №1988/17. Іноді трапляється $і$ інша нумерація поховань.

136 Боровский, Я. Е., Архипова, Е.И., Калюк, А. П., \& Сыромятников, А. К. (1988). Археологические исследования, 69-70; Мовчан, І., Боровський, Я., \& Гончар, В. Нові знахідки, 115-116. черепа та правої ноги - по одній пастовій намистині; у ділянці шиї та грудей - підвіска 3 золотого дроту з напускною пастовою намистиною та намисто із семи срібних ажурних, чотирьох сердолікових і двох пастових намистин; на кожній руці - по одному срібному дротовому браслету та по два персні з золотого дроту; в ділянці поперека - срібна підковоподібна спіралеконечна фібула; в ділянці таза - срібний дирхем (350-365/961976 pp. - ?); біля лівої ступні - залізні обручі на дужках від відра ${ }^{133}$.

16. Київ-I, поховання б/№ 1972 р. по вул. Десятинній, 2. Під підлогою житла $\mathrm{XI}$ ст. виявлено передню частину кінського кістяка в анатомічному порядку. На тому самому рівні розчищено рештки поховальної споруди у вигляді рівчаків від двох лаг (поздовжніх - ?) зі слідами зотлілого дерева, шириною $0,15-0,2$ м, завдовжки 1,4-1,6 м, що лежали паралельно на відстані 2,2 м за віссю захід - схід. Серед інших, переміщених, кісток коня виявлено кілька людських (рис. 10, 2). Інвентар: поруч із черепом коня - залізне вістря списа; в ділянці грудної клітини - залізна підпружна пряжка; в заповненні - дві бронзові серцеподібні бляшки ${ }^{134}$.

17. Київ-I, поховання № $1 / 1988{ }^{135}$ по вул. Володимирській, 2. Пограбоване ще в давнину поховання було здійснено в зрубній гробниці $(3 \times 3$ м), на 0,8 м опущеній у ма- терик. Її було споруджено «в обло» 3 колод діаметром 0,16 м. За деякими свідченнями, споруда мала кутові стовпи. Дно підмазане глиною. У заповненні зафіксовано багато вугілля (від згорілого перекриття - ?) та череп собаки. Внутрішній простір камери був розділений тонкою дошкою навпіл: у північній частині, шириною 1,2 м, виявлено поховання воїна (збереглися лише кістки ніг) західного орієнтування, а у південній, завширшки $1,8 \mathrm{M},-$ супутнє захоронення коня 3 підігнутими ногами. Інвентар: біля західної стінки - залізні обручі та дужка від відра; біля кінської щелепи - залізні вудила; можливо, до цього ж поховання належать знайдені неподалік бронзовий псалій, залізна шпора, ніж, срібна лунниця та бляшка ${ }^{136}$.

18. Київ-I, поховання б/№ 1988 р. по вул. Володимирській, 2. Поховання пограбоване ще в давнину. Могильна яма $(4 \times 4 \times 0,85$ 1,05 м) була орієнтована кутами за сторонами світу. До її стінок щільно прилягали вінця зрубу, спорудженого «в обло» 3 колод діаметром близько 0,2 м. Кінці вінець виступали на $0,2-0,3$ м, для чого у стінках могильної ями було викопано додаткові виступи. У виступі північно-західної стіни виявлено окуття лопати, встромлене в материковий борт. Рештки померлого не збереглися; лише у верхній частині заповнення могильної ями знайдено людський череп. Інвентар: біля північно-за- 


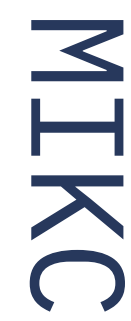

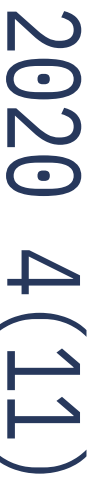

137 Боровский, Я. Е., Архипова, Е. И. , Калюк, А. П., \& Сыромятников, А. К. (1988). Археологические исследования, 69-70; Мовчан, І., Боровський, Я., Гончар, В. Нові знахідки, 115.

138 Івакін, Г. Ю., \& Козюба, В. К. Нові поховання X-XI ст., 39-40; Михайлов, К. А. Элитарный погребальный обряд, 209; Хамайко, Н. Поховання коня, 118,120 . хідної стінки ями - залізні умбон і оковки від щита; в північному куті - залізний серп, срібне кілечко та фрагменти кістяного гребеня у футлярі; в північно-східній частині - 3 срібн бляшки з залишками шкіри, обгорнуті шаром берести (залишки футляра - ?); у перевідкладеному заповненні ями та перекопі - фрагменти кованого з окремих пластин шолома 9 срібних гудзиків, 74 срібні поясні (?) бляшки, три срібні поясні наконечники, срібна пряжка, 6 сердолікових 10-гранних, 11 скляних і зернена срібна намистини, 4 срібні накладки для двох дерев'яних чаш, фрагмент ножа, невизначені залізні предмети, кам'яна вставка для персня, оселок ${ }^{137}$

19. Київ-I, поховання № $2 / 1998$ на Софійській пл. Камеру $(2,4 \times 2,3$ м), орієнтовану стінами за сторонами світу, по діагоналі прорізала траншея перекопу. Зведена 3 горизонтальних дощок товщиною 3-4 см, поставлених на ребро; кінці дощок північної та південної стін виступали на 0,1-0,2 м. Дно камери вкрито поперечними дошками. У північно-східному куті збереглась частина перекриття 3 тонких поперечних дощок. Уздовж східної стінки виявлено рештки кістяка південного орієнтування, що належав дівчинці 6-7 років (рис. 11, 2). Інвентар: на черепі та біля нього - 2 срібні скроневі кільця та намисто 38 сердолікових намистин; біля південної стінки камери - ручка та обручі від відра; у південно-східному куті - два невеликі гли- няні горщики. Поруч (на перекритті - ?) виявлено предмети чоловічого призначення (за К. О. Михайловим, від зруйнованої кремації; за Н. В. Хамайко, як символ чоловічого кенотафу): набір верхового спорядження (два стремені, 3 підпружні пряжки, 2 кільця 3 петлями для заживання кінців ременів), 10 вістер стріл, бронзовий поясний набір (пряжка, наконечник, 8 фігурних накладок), вушко від казана (?), дві квадратні заклепки з петлями та кільцями, бронзові накладка 3 прямокутним отвором і трикутна в перетині пластина (від скриньки - ?) ${ }^{138}$.

20. Київ-I, поховання № 30/1999 у садибі Михайлівського Золотоверхого монастиря. У могильній ямі $(2,75 \times 2,15 \times 0,85$ м), орієнтованій за віссю захід - схід, виявлено рештки камери $(2,25 \times 1,75$ м). Камеру зведено «в обло» 3 дощок шириною 0,1-0,12 м 3 кінцями, що виступають на 0,2 м. Дно викладено поперечними дошками шириною близько 0,15 м. Знахідки близько 20 цвяхів, які лежали переважно смугами вздовж західної та східної стінок, на думку авторів розкопок, свідчать про наявність двох поперечних брусів, що утримували перекриття камери. Скелет дівчинки 11-12 років знайдений у центрі камери в переміщеному стані; на думку К. О. Михайлова, зруйнована верхня частина кістяка та знахідка намиста в ділянці таза свідчать про сидяче положен- 

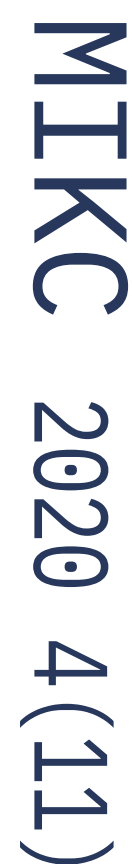

139 Івакін, Г. Ю., Козубовський, Г. А., Козюба, В. К., Поляков, С. Є., \& Чміль, Л. В. (1999). Дослідження на території Михайлівського Золотоверхого монастиря у 1998-1999 рр. Археологічні відкриття в Україні 1998-1999, 5; Івакін, Г. Ю., Козюба, В. К. Нові поховання X-XI ст., 40-41; Михайлов, К. А. Элитарный погребальный обряд, 210.

140 Івакін, Г. Ю., Козубовський, Г. А., Козюба, В. К., Поляков, С. $€$., \& Чміль, Л. В. Дослідження на території Михайлівського Золотоверхого монастиря, 5-6; Івакін, Г. Ю., \& Козюба, В. К. Нові поховання X-XI ст. 41-43. ня небіжчиці. Поховання пограбоване ще в давнину (?) (рис. 11, 3). Інвентар: у ділянці таза - дві сканні круглі підвіски; на пальцях правої руки - три срібні перстні; ліворуч від кістяка - ще один перстень і набірний односторонній кістяний гребінь із залишками футляра; біля західної стінки камери - уламки залізних пластин дерев'яної скрині; попід західною стінкою камери - залізні деталі відра, невеликий залізний ключ і ніж ${ }^{139}$.

21. Київ-I, поховання № 49/1999 у садибі Михайлівського Золотоверхого монастиря. У котловані $(4 \times 3,45$ м), орієнтованому кутами за сторонами світу і заглибленому на 0,9 м від рівня давньої поверхні, зафіксовано сліди камери $(3,2 \times 2,7$ м). Остання рублена «в обло» 3 дощок завширшки 0,17-0,2 м із торцями, що виступають на $0,15-0,2$ м. Кістяк дівчини 16-18 років мав західне орієнтування і зберігся лише частково. Права рука зігнута в лікті та покладена на попереку (рис. 11, 4). Інвентар: на черепі - стрічки очілля зі срібним шитвом; праворуч від черепа - золоте дротове кільце 3 напускною пастовою намистиною та ромбоподібна пластина зі срібної фольги; у ділянці шиї - намисто 3 трьох срібних позолочених напівсферичних підвісок, двох поясних накладок угорського типу з приклепаними вушками, 19 дрібних скляних і 14-гранної пастової намистин; на грудях - фібула типу «Терслев» і фібула 3 зав'язаними кінцями, з'єднані ланцюжком із двома нанизаними на нього перснями; біля лівого ліктя - хрест скандинавського типу та залишки шкіряної сумки чи гаманця зі срібними скобами та срібною хрестоподібною накладкою; на правій плечовій кістці - залізний ніж із дерев'яною ручкою та обмоткою зі срібного дроту; в 0,7 м на південний схід від кістяка - залишки дерев'яної скриньки (оковка, кільце, навісна петля), а всередині скриньки - бронзова напівсферична чаша, пружинні ножиці, пінцет, срібна ремінна пряжка з залізним язичком, 27 скляних фігурних нашивок на одяг і циліндрична пастова намистина 140

22. Київ-I, поховання б/№ 2002 р. по вул. Великій Житомирській, 2. Могильна яма $(3,2 \times 3 \times 0,7 \mathrm{M})$, орієнтована стінами за сторонами світу, була обшита дошками товщиною 5-6 см, кінці яких виступали на 0,3-0,35 м. Зверху споруда мала перекриття з поздовжніх колод діаметром 0,18-0,2 м. Частково збережений кістяк західного орієнтування лежав на своєрідних дерев'яних ношах, накритих шкірою. Останні складалися 3 двох поздовжніх колод завдовжки 2,15-2,2 м, діаметром 0,1-0,12 м, та трьох поперечних, довжиною 1,3 м, діаметром 0,08 м (рис. 9, 3). Інвентар: вздовж правого стегна - меч із залишками дерев'яних, обшитих шкірою, піхов із мідною бутероллю і пряжка від портупеї; вище го- 
141 Мовчан, I. І., Гончар, В. М., Ієвлев, М. М., \& Козловський, А. 0. (2002). Звіт про археологічні дослідження на вул. Велика Житомирська, 2. Науковий архів Iнституту археологї̈ HАHУ, ф. е., № 2002/84, 3-27; Мовчан, I. І., Боровський, Я. Є., Гончар, В. М., \& Ієвлев, М. М. Дослідження в «городі» Володимира, 190.

142 Гамченко, С.С. Розкопи 1926 року, 29-30; Хамайко, Н. Поховання коня.

143 Мельник, Е. Н. Раскопки в земле лучан, 555 . лови небіжчика - залишки берестяного, обшитого шкірою, сагайдака 3 двома залізними окуттями, бронзовою накладкою кришки та 26 вістрями стріл усередині; в ділянці таза залізний ніж із дерев'яним руків'ям, точильний брусок і залишки шкіряного гаманця (сумки - ?), оздобленого срібними бляшками, з чотирма візантійськими монетами всередині; ліворуч від кістяка - залізні обручі та дужка від відра; біля плеча - дві ажурні срібні намистини (від корзна - ?) ${ }^{141}$.

\section{1. Камера-кенотаф}

23. Київ, поховання 115. Поховальна споруда являла собою грунтову яму $(3 \times 2,5 \times 0,7$ м). Хоча в наявних описах комплексу зазначено, що вона мала овальні обриси, наявні замальовки дали змогу Н. В. Хамайко охарактеризувати форму ями радше як прямокутну з заокругленими кутами. В iї південно-західній частині (?) виявлено кістяк коня на правому боці, в бойовому спорядженні, череп обгорнуто лубом. За Н. В. Хамайко, біля задніх ніг кінського кістяка (ймовірно - ближче до стінки) знайдено залишки дерева, а між кінським кістяком і дерев'яним відерцем залишено порожнє місце, що могло символічно відводитися решткам померлої людини. Інвентар: біля голови коня - залізні вудила та залишки вузди, прикрашеної понад 200 бронзовими (і срібними - ?) бляшками; у ді- лянці середньої частини хребта - залишки сідла та підпруги, залізні стремена, підкова, фрагменти дерев'яного сагайдака та лука; біля ніг - залізні вістря списа та 11 стріл, ніж, кільце, аморфні залізні предмети та точильний камінь 3 пісковику; в 1,17 м від ніг коня - залишки відра ${ }^{142}$.

\section{2. Камери-наслідування}

\section{1. Камери з гробовищами}

24. Городище, курган № 4. $\mathrm{h}=2,15$ м, $\varnothing \approx$ 11,8 м. У 1,5 м нижче горизонту влаштовано камеру $(2,9 \times 1,6 \times 1 \mathrm{M})$ із товстих березових колод, вкритих корою. Перекриття, що виступало за межі гробниці, споруджене з таких самих колод, обтесаних тільки з верхнього, зовнішнього боку. Зверху на перекритті лежав скелет великого птаха. Всередині камери стояла труна $(2 \times 0,5 \times 0,45$ м), поздовжні стіни якої складені з брусів завтовшки до 0,25 м, поперечні - 3 дощок. Скелет (жіночий - ?) орієнтований головою на південний захід. Праву руку покладено на тазову кістку, ліва випростана вздовж тіла; ноги прямо. Інвентарю немає ${ }^{143}$

25. Старожуків-1, курган № $10 . \mathrm{h}=1,8 \mathrm{M}$, $\varnothing \approx 8,9$ м. На рівні горизонту виявлено дерев'яний накат $(3,6 \times 2,6$ м), орієнтований за віссю північ - південь, скріплений по кутах залізними цвяхами. Уздовж східного краю 


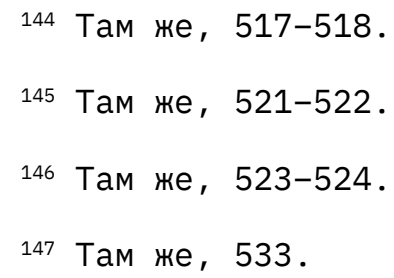

накату йшла широка смуга вугілля. Він перекривав поховальну споруду майже таких самих розмірів висотою $0,6-0,7$ м, зведену 3 тесаних брусів. На іiі дні К. М. Мельник описує складну систему суміжних «камер» (приблизно 2,6×0,5 м), які, очевидно, являли собою залишки гробовищ. Ці «камери» були розділені поздовжніми дошками, покладеними на ребро, паралельно кістякам, і вкриті такими самими товстими дошками. Дно поховальної споруди також викладено широкими брусами. Один із кістяків покладений головою на північний захід, руки та ноги випростано. Інвентар: окиснений залізний предмет (імовірно - наконечник списа або дротика) на тазових кістках. Інше поховання (пізніше - ?) - західного орієнтування, 3 випростаними кінцівками, обгорнуте берестою. Без інвентарю ${ }^{144}$.

26. Старожуків-2, курган № $12 . \mathrm{h}=2,4$ м, $\varnothing \approx 17,1$ м. В $0,2-0,3$ м вище горизонту виявлено перекриття склепу $(2,7 \times 1,2$ м), скріпленого значною кількістю цвяхів. Усередині, на глибині 0,7 м від горизонту, стояла тонка дощата труна, кришка та дно якої були обпалені зсередини. Кістяк із випростаними кінцівками мав західне орієнтування. Інвентар: обабіч черепа - по чотири кілечка з товстого срібного дроту; в ділянці шиї - намистини, сердолікова (невизначеного типу), золотоскляна і дв срібні; на пальці правої руки - кільце з тов- стого бронзового дроту; у насипу - половина бронзового пластинчатого браслета та фрагмент залізних «щипців» (пінцета - ?) ${ }^{145}$.

27. Білів, курган № $2 . \mathrm{h}=1,2 \mathrm{м}, \varnothing \approx 7,6$ м. На глибині 1,5 м від вершини виявлено перекриття широкого склепу з товстих дощок, обвуглених ізсередини. Всередині, на глибині 2,7 м, лежав кістяк головою на захід. Він оточений великою кількістю залізних цвяхів, що може свідчити про наявність гробовища. Кисть лівої руки на краю таза, права простягнута. Обидві ноги зігнуті в колінах, «ніби йдуть направо». Інвентар: біля нижньої щелепи - золота сережка («обол мертвих» - ?); біля шиї - по одній намистині зі срібла та жовтої композиції; біля правого плеча - невизначений залізний предмет; біля правої кисті - залізний ніж; на пальці - срібне дротове кільце ${ }^{146}$.

28. Білів, курган № $36 . \mathrm{h}=1 \mathrm{M}, \varnothing \approx 6,4$ м. На рівні горизонту зафіксовано перекриття склепу $(2,3 \times 1,1$ м) із цілих колод. На глибині 1 м нижче горизонту - труна $(2 \times 0,5$ м $)$ із товстих дубових дощок; на ній і під нею прошарки золи. Скелет покладено головою на захід, руки випростані вздовж тіла. Права нога дещо відсунута вбік, ліва випростана. Інвентар: залізний предмет (кресало - ?) і кремінь між гомілками ${ }^{147}$.

29. Пересопниця, курган № 7. $\mathrm{h}=0,8 \mathrm{м}$, $\varnothing \approx 6$ м. На глибині 2 м (від вершини - ?) ви- 
148 Там же, 536

149 Самойловський, І. М. (1954).

Слов'янський могильник на р. Пронівщині під Києвом. Археологія, 3, 154.

150 Килиевич, С. Р., \& Харламов, В. А. (1986). Раскопки Федоровского монастыря в Киеве. Археологические открытия 1984, 241; Мовчан, I., Боровський, Я., \& Гончар, В. (2003). Нові знахідки, 114-115.

151 Івакін, Г. Ю., Козубовський, Г. А., Козюба, В. К., Поляков, С. Є., \&

Чміль, Л. В. Дослідження на території Михайлівського Золотоверхого монастиря, 5; Івакін, Г. Ю., \& Козюба, В. К. Нові поховання X-XI ст., 38-39. явлено дерев'яну камеру (4×3 м), вкриту дощатим перекриттям і скріплену цвяхами. На 0,35 м нижче стояла домовина «звичайних розмірів», вкрита товстою дошкою. Кістяк лежав головою на захід, із випростаними руками та ногами. Інвентар: срібне дротове кільце на пальці правої руки ${ }^{148}$.

30. Совки, курган № $6 . \mathrm{h}=1 \mathrm{м}, \varnothing \approx 7 \mathrm{м}$. У насипу виявлено уламок кераміки з лінійним орнаментом. Могильна яма мала розміри $3,5 \times 2,25 \times 0,8$ м. На глибині 0,4-0,5 м виявлено сліди трухлявого дерева, а в куті ями - залізний цвях. Кістяк, орієнтований головою на захід, лежав на товстій дубовій дошці від труни. Права рука лежала на тазових кістках, ліва випростана вздовж тіла Інвентарю немає ${ }^{149}$.

31. Київ-I, поховання на пл. Калініна (Михайлівській) 1984 р. Поховання частково порушене під час земляних робіт, унаслідок чого пошкоджено південну частину камери і втрачено ймовірну частину інвентарю праворуч від небіжчика. Виявлено дерев'яну споруду $(3,65 \times 0,9 \times 0,75$ м) з горизонтальних дощок-горбилів, поставлених опуклою стороною всередину і закріплених за допомогою чотирьох кутових стовпів. Зверху зафіксоване дощате перекриття. Кістяк лежав у дерев'яній труні, збитій цвяхами і орієнтованій за віссю захід-схід. Руки схрещено на животі (рис. 12, 1). Інвентар: біля коліна - бойова сокира; під лівою рукою - залізний ніж із кістяною колодкою і фрагменти шкіряного ременя з бронзовими заклепками; в головах і біля лівого стегна - обручі від двох відер (в одному з них - на рівні стегон - 16 астрагалів) ${ }^{150}$.

32. Київ-I, поховання № 12/1997 у садибі Михайлівського Золотоверхого монастиря. Поховання здійснене в могильній ямі (3,5×2,6×0,5 м), орієнтованій за віссю захід схід. Від поховальної камери залишилась лише колода чи напівколода західної стінки діаметром 0,21 м, розташована на відстані 0,2-0,3 м від відповідної стінки ями. Біля північної стінки виявлено жіночий кістяк поганої збереженості та залишки домовини $(1,49 \times 0,56$ м), збитої цвяхами. Інвентар: праворуч від черепа - скроневе кільце зі срібного дроту; в ділянці шиї - намисто 316 скляних, 7 сердолікових (6 14-гранних і однієї призматичної 8-гранної) і однієї кришталевої намистин, бронзової пронизки та 7 срібних пустотілих кульок; на грудях - 5 бронзових гудзиків; в ділянці таза - 3 кам'яні вставки перснів, залізний ніж і фрагмент деревини, вкритий золотою фольгою (скриньки - ?); біля ніг - денце берестяного козубу з двома мініатюрними ліпними необпаленими горщиками всередині та фрагмент блюда 3 візантійського скла ${ }^{151}$. 
152 Мовчан, И. И. (1973). Отчет о раскопках Китаевского поселения и могильника. Науковий архів Iнституту археологї НАНу, ф. е., 1973/22, 6-8; Мовчан, I. I. Давньокиївська околиця, 151.

153 Мовчан, И. И. Отчет о раскопках, 8-9; Мовчан, I. I. Давньокиївська околиця, 152

154 Мовчан, И. И. Отчет о раскопках, 10 Мовчан, I. I. Давньокиївська околиця, 152-153.
33. Китаїв-1, курган № 1/1973. h=0,9 м, $\varnothing=7$ м. У східній частині - чотири впускні поховання у спільній могильній ямі. В центрі кургану виявлено дві могильні ями, розмірами 2,5×0,9 м, розташовані на відстані 0,4 м. Ями обкладені сосновими колодами діаметром 0,15 м, які утворювали камери, споруджені у зрубній техніці. Зверху вони були перекриті поздовжніми колодами такого самого діаметру (хоча в звіті про перекриття не сказано; не показане воно і на кресленні). Їх глибина - 0,8 м (хоча, зважаючи на розріз, північна яма була глибшою). Знайдено фрагменти залізних цвяхів. Всередині південної камери виявлено дубову труну $(1,65 \times 0,6 \times 0,45 \mathrm{~m})$, а в ній - кістяк головою на захід. Руки зігнуті в ліктях, праву покладено в ділянку живота, ліву - на груди. Ліва нога зігнута в коліні (рис. 12, 2). Інвентар: бронзове скроневе кільце у ділянці лівого вуха. В північній камері також помітні сліди труни $(2 \times 0,55$ м). Кістяк мав аналогічне орієнтування, руки зігнуто в ліктях і покладено кистями на плечі. Інвентар: на пальці правої руки - срібний пластинчатий перстень із напаяним восьмилисником, до якого кріпився мініатюрний хрест; в ділянці живота - невелика намистина; в ділянці правого вуха бронзове скроневе кільце ${ }^{152}$.

34. Китаїв-1, курган № 2/1973. h $=1$ м, $\varnothing=8,5$ м. У насипі - багато фрагментів ке- раміки X-XI ст., тваринні кістки, шматки шиферу, глиняне грузило. На рівні горизонту, південніше центра кургану, простежено випалений майданчик діаметром 0,7 м. Могильну яму $(2,5 \times 0,9 \times 1,2$ м) було обкладено дубовими дошками, в заповненні була велика кількість вугликів. Усередину вміщено дерев'яну труну менших розмірів. Кістяк мав західне орієнтування, руки зігнуті в ліктях i покладені кистями на плечі. В лівій скроні великий пролом, невеликий отвір зафіксовано і в правій потиличній частині (рис. 12, 3). Інвентар: біля лівого стегна - бронзова ліроподібна пряжка, два бронзові кільця (поясні - ?) та залізне фігурне кресало з кременем ${ }^{153}$.

35. Китаїв-1, курган № 3/1973. h $=1$ м, $\varnothing=9,6$ м. У насипі - кераміка Х ст. Виявлено могильну яму $(2,5 \times 1,2$ м), а поперек неї, по центру - колоду діаметром 0,22 м, що на 0,6 м виступала за межі ями 3 обох боків. На північній стінці помічено обкладку 3 колод, траплялись залізні цвяхи. На глибині 1 м зафіксовано залишки дощатої труни, зверху заваленої поздовжніми колодами від перекриття могильної ями. Кістяк зотлів майже повністю. У правій гомілковій кістці виявлено вістря стріли (рис. 12, 4). Інвентар: між ногами - бронзова ліроподібна пряжка, біля правого стегна - бронзове кільце (поясне - ?) ${ }^{154}$. 
155 Ливох, Р. Большие курганы, 490: Liwoch, R. Zabytki z wykopalisk Teodora Nieczuja-Ziemięckiego, 85-87.

156 Мельник, Е. Н. Раскопки в земле лучан, 553.

157 Там же, 563.

158 Там же, 574

159 Там же

\section{2. Наземні склепи}

36. Підгірці, «великий здвоєний курган» № $2 . \mathrm{h} \approx 2$ м, $\varnothing \approx 16$ м. У насипі траплялося деревне вугілля. Простежено залишки дерев'яних конструкцій. Безпосередньо під насипом, на глибині 2 м від вершини, виявлено чоловічий кістяк головою на південний захід. Інвентар: біля правого стегна - залізна, інкрустована міддю сокирка-чекан; на пальцях обох рук - по золотому пластинчатому персню; на правому плечі - бронзовий енколпіон; на грудях - срібний хрест; у роті - золотий дріт («обол мертвих»); на тазових кістках - залізний серп і невизначений залізний інструмент (кинджал - ?); біля лівого стегна - залишки 2 відер (в одному з них - кістки тварин і ніж) ${ }^{155}$.

37. Гірка Полонка, курган № $6 . \mathrm{h}=1,8$ м, $\varnothing \approx 8,9$ м. На рівні горизонту - поховальна споруда 3 товстих дощок, розділена поздовжньою дошкою на дві камери завширшки по 0,4 м. У північній камері, на підсипці з глини та вугілля, лежав кістяк головою на захід, із простягнутими вниз руками. Інвентар: під правою кистю - залізний ніж і S-подібне скроневе кільце; на пальці правої руки срібне дротове кільце ${ }^{156}$.

38. Теремно, курган № $1 . \mathrm{h}=2 \mathrm{м}, \varnothing \approx$ 10,8 м. На рівні горизонту зведено низький дерев'яний склеп $(2,3 \times 1,2$ м), а всередині - труна, сколочена залізними цвяхами. На iii кришці та під дном - шар золи. Кістяк із випростаними кінцівками мав західне орієнтування. Інвентар: вздовж правої плечової кістки, між стінками склепу та труни - залізний спис (?); на пальці лівої руки - витий срібний перстень ${ }^{157}$.

39. Новосілки (Боромля), курган № 2. $\mathrm{h}=$ 2,15 м, $\varnothing \approx 10,8$ м. На рівні горизонту - поховальна споруда $(3,1 \times 1,5$ м), сколочена залізними цвяхами, посипана золою $з$ дрібним вугіллям. Кістяк лежав на глибині 0,2 м, головою на південний захід. Під ним зафіксовано тонку дошку, що, можливо, лишилася від зотлілого гробовища. Права рука простягнута вздовж тіла, кисть лівої покладено на таз; ноги розведені в колінах. Без інвентарю ${ }^{158}$.

40. Новосілки (Боромля), курган № 4. $\mathrm{h}=2,4 \mathrm{м}, \varnothing \approx 11 \mathrm{м}$. На 0,6 м вище рівня горизонту виявлено широкий склеп із тесаних брусів. На горизонті - скелет західного орієнтування; руки простягнуті вздовж тіла. Інвентарю немає ${ }^{159}$.

41. Ставок (Ставка), курган № 2. $\mathrm{h}=$ 1,9 м, $\varnothing \approx 9,5$ м. Дещо вище рівня горизонту виявлено широке дощате перекриття склепу, на кінцях скріплене цвяхами. Склеп $(3,1 \times 1,55$ м) зведено 3 товстих дощок та кутових стовпів, по внутрішніх стінках простежено шар золи. Всередині, на рівні горизон- 
160 Там же, 556.

161 Там же, 515

162 Там же, 518

163 Там же, 530. ту, вміщено дощату домовину $(2,2 \times 0,94$ м), також збиту великою кількістю цвяхів. Кістяк мав західне орієнтування, руки та ноги випростані. Інвентарю немає ${ }^{160}$.

42. Старожуків-1, курган № $2 . \mathrm{h}=1,57 \mathrm{M}$, $\varnothing \approx 8,3$ м. На висоті 0,4 м над горизонтом виявлено горизонтальний дерев'яний поміст, що покривав споруду з дощок $(2,7 \times 0,96 \times 0,4$ м), скріплену цвяхами. Остання була розділена широкою дошкою на дві рівні поздовжні частини. Північна 3 них виконувала функцію власне труни: тут виявлено кістяк, обкладений берестою. Південна камера порожня. Скелет головою орієнтований на захід; руки витягнуті вздовж тіла, кістки лівої частково порушені. Інвентар: біля правої кисті - залізний ніж, біля лівої стопи - срібне дротове кільце. Обабіч склепу - ще два поховання: без інвентарю та без анатомічного порядку; одне 3 них - у гробовищі ${ }^{161}$.

43. Старожуків-1, курган № $12 . \mathrm{h}=2 \mathrm{м}$, $\varnothing \approx 11,1$ м. У середніх шарах насипу траплялося вугілля. На рівні горизонту влаштовано склеп із брусів $(2 \times 1,4 \times 1$ м). Він покритий суцільним помостом дещо більшого розміру 3 товстих поздовжніх дощок, скріплених довгими залізними цвяхами з чотирма поперечними. Скелет лежав на підсипці зі світлої глини, золи та вугілля, головою на захід. Кисті обох рук покладено на відповідних тазових кістках, ноги - прямо. На кістках обсипка з золи та вугликів. У ногах, iз правого боку, стояв роздавлений гончарний горщик. Інвентарю немає. В 1,7 м від склепу, паралельно йому, влаштоване більш пізнє дитяче поховання у труні, з випростаними кінцівками. Інвентар: дві малі намистини з синього скла та бурштину на шийних хребцях ${ }^{162}$

44. Білів, курган № 28. $\mathrm{h}=3,3$ м, Ø 17,5 м. У 1,5 м вище горизонту виявлено перекриття склепу $(3 \times 2,8 \times 0,8$ м $) 3$ брусів, а на висоті 0,7 м - ще одного, меншого $(2,3 \times 1,1 \mathrm{м})$; обидва збиті залізними цвяхами. На дні останнього, приблизно на рівні горизонту, стояла домовина «звичайних розмірів». Скелет був орієнтований головою на південний захід, кисті рук складено в ділянці таза. Інвентарю немає ${ }^{163}$.

45. Білів, курган № $32 . \mathrm{h}=4$ м, Ø 22,6 м. Верхня частина насипу (до 1,5 м) складалася з чистої глини. На висоті близько 2 м над рівнем горизонту виявлено склеп $(3,1 \times 2,4 \times 1$ м $)$, скріплений значною кількістю великих залізних цвяхів, із перекриттям і підлогою у вигляді дерев'яних накатів. Всередині була труна $(2 \times 0,7$ м) із товстих дубових дощок, також скріплених цвяхами. Скелет мав західне орієнтування. Руки зігнуті в ліктях: праву кисть покладено на грудях, ліву - на попереку. Інвентар: біля голови - залишки золотого шиття та тонкий 
164 Там же, 531-532.

165 Там же, 532-533.

166 Там же, 540-542; Корзухина, Г. Ф. 0 технике тиснения, 45-46.

167 Штейнгель, Ф.Р.(1905). Раскопки курганов в Волынской губернии, произведенные в 1897-1900 ге. Киев: Типо$\infty$
0 графия Н.А. Гирич, 6-7. односторонній гребінь, праворуч від шиї частина срібного медальйону (?), біля лівого стегна - залізний ніж ${ }^{164}$.

46. Білів, курган № $35 . \mathrm{h}=2,25 \mathrm{м}, \varnothing \approx$ 10,5 м. У південній частині насипу майже від самої вершини було помітно зотліле дерево, імовірно - залишки перекриття. Нижче виявлено широкий склеп із дубових брусів, скріплених залізними цвяхами. На глибині 1,3 м від вершини - труна $(1,8 \times 0,6$ м) із товстих брусів, обсипана золою; на зольній підсипці. Кістяк лежав головою на захід, із випростаними руками та ногами. Інвентар: між стінкою склепу та домовиною - залишки відра; біля правої скроні - срібне дротове кільце; поблизу лівої стопи - тальковий оселок ${ }^{165}$.

47. Пересопниця, курган № 29. $\mathrm{h}=2,7$ м, $\varnothing \approx 11,8$ м. На висоті 0,5 м від рівня горизонту виявлене дощате перекриття склепу $(3 \times 2$ м) 3 великою кількістю цвяхів. Дно склепу являло собою тонкий дерев'яний поміст, вистелений березовою корою. Зверху на ній, на рівні горизонту, стояла труна $(2 \times 0,6$ м) iз тонких дощок, також збита цвяхами. Ї̈̈ кришка посипана шаром золи та дрібного вугілля, зольну підсипку виявлено і під дном склепу. Кістяк орієнтований головою на південний захід. Права рука випростана, ліва покладена кистю на таз. Інвентар: у західному куті склепу, між його стінкою та гробовищем - залишки відра; в ділянці шиї - сильно розкладений срібний медальйон із вирізом посередині (?); на пальці правої руки - срібне пластинчате кільце; поблизу таза - дві бронзові пряжки та два бронзові поясні кільця; біля лівого стегна - залізні ключ, ніж із кістяною колодкою та кинджал із вигнутим лезом; біля лівого коліна - маленькі бронзові терези; поблизу лівої гомілки - деталі ще одних терезів і дерев'яний ящик, усередині якого - набір штампів для виготовлення прикрас, невеликий молоток і ковадло ${ }^{166}$.

48. Рогачів, курган № 5. $\mathrm{h}=1,54$ м; $\varnothing=$ 6,5 м. На висоті 0,6 м від горизонту виявлено зотлілу балку, на висоті 0,3 м - домовину $(2,73 \times 1,15$ м), споруджену з брусів без застосування цвяхів. На перекритті $з$ дощок знайдено золу та фрагменти кругової кераміки. Кістяк орієнтований головою на захід. Права рука випростана, ліва покладена кистю на поперек. Інвентар: на правій руці - срібний спіральний перстень; біля голови, за межами домовини, - невелике срібне кільце; на ногах - залишки шкіряного взуття ${ }^{167}$.

49. Басів Кут, курган № 7. $\mathrm{h}=1,2$ м, Ø $\approx$ 16,2 м (розораний). На рівні горизонту влаштовано склеп із соснових брусів $(2,8 \times 1,7 \times 1$ м) із дубовими стовпами по кутах, покритий горизонтальним помостом. На перекритті та на дні - товстий шар берести. Всередині була труна $(2 \times 0,8$ м) із товстих дощок, також вистелена березовою корою ззовні та зсереди- 
168 Мельник, Е. Н. Раскопки в земле лучан, 546-547.

169 Виєзжів, Р. I. (1954). Розкопки курганів у Коростені та поблизу Овруча в 1911 р. Археологія, 9, 146.

170 Мельник, Е. Н. Раскопки в земле лучан, 552-553.

171 Там же, 574. ни. В південному куті склепу, поза гробовищем знайдено купку вугілля та уламки двох гончарних горщиків. Скелет лежав головою на північний захід, обидві руки випростані вздовж тіла. Інвентар: біля лівої кисті - залізний ніж у дерев'яних піхвах і тальковий оселок; зліва в ногах - залишки відра з залізними дужкою та обручами, 2 бронзовими пластинками та 6 срібними скобами ${ }^{168}$.

50. Коростень, курган № 5. $\mathrm{h}=4,9$ м; Ø 18,2 м. На глибині 3,25-3,85 м від вершини виявлено три скупчення великих каменів, вагою 16-96 кг, від 3 до 9 у кожному скупченні. Під камінням, на глибині 4,65 м від вершини, виявлено пляму $(3,5 \times 2,4$ м) зі слідами зотлілого дерева та 11 залізними цвяхами по контуру. На рівні горизонту - кістяки чоловіка і жінки головами на захід, із «різним» положенням рук. Інвентар: біля черепа чоловічого кістяка - обручі та ручка відра; біля правого плеча - бойова сокира; біля правого стегна - залізний ніж та оселок; біля шиї «шиферна застібка» (?); бронзова пряжка (фібула - ?); на пальці лівої руки - срібне вите кільце; в ногах - роздавлена глиняна посудина; біля черепа жіночого кістяка -5 срібних S-подібних кілець, 5 бочкоподібних зернених намистин, 14 сердолікових намистин (у т. ч. 1 призматична та 2 «плиткоподібні»), 2 підвіски з сердоліку та кольорового каменю та 3 скляні намистини; на пальці - срібне пластинчате кільце; біля пояса - срібний бубонець ${ }^{169}$.

\section{3. Земляні камери}

51. Гірка Полонка, курган № 2. $\mathrm{h}=1,5$ м, $\varnothing \approx$ 8,9 м. На висоті 0,6 м від горизонту виявлено пласт зотлілого дерева та багато фрагментів кераміки. На рівні горизонту - дощате перекриття $(3,12 \times 1,8$ м), орієнтоване $з$ південного заходу на північний схід; у його західному куті - залізний цвях і частина залізного обруча від відра. Безпосередньо під ним - домовина $(2,1 \times 0,5$ м) із кістяком південно-західного орієнтування. Руки простягнуті вздовж тіла, ліва трохи зігнута в лікті. Інвентарю немає ${ }^{170}$

52. Новосілки (Боромля), курган № 3. $\mathrm{h}=0,9$ м, $\varnothing \approx 6,7$ м. На глибині 0,3 м нижче горизонту виявлено широкий дерев'яний поміст, що покривав собою дощату домовину $(2 \times 0,45 \times 0,4$ м). Усередині - кістяк західного орієнтування. Права рука покладена на таз, ліва випростана вздовж тіла; ноги також випростані. Інвентар: срібне S-подібне кільце на лівій скроні. Поруч, у тій самій могильній ямі, лежав ще один скелет, із випростаними кінцівками. Сказано, що він був оріснтований головою на схід, однак обидва черепи при цьому сходилися скроня до скроні (?). Без інвентарю ${ }^{171}$. 
172 Там же, 523.

173 Там же, 526-527.

174 Там же, 529.

175 Там же.

176 Антонович, В. Б. (1893). Раскопки в стране древлян. Материалы по археолоzии Poccuu, 11, 59
53. Білів, курган № $1 . \mathrm{h}=1,26 \mathrm{м}, \varnothing \approx$ 8,3 м. Нижче рівня горизонту виявлено дощатий поміст, обвуглений знизу. На глибині 2 м від вершини на розчищеному підгрунті (материку) стояла дощата труна, сколочена залізними цвяхами. Всередині неї - скелет головою на південний захід, руки та ноги випростані. Інвентарю немає ${ }^{172}$.

54. Білів, курган № $12 . \mathrm{h}=2,45 \mathrm{м}, \varnothing \approx$ 11,8 м. На рівні горизонту - поховання малої дитини (впускне - ?). Трохи нижче - пласт золи, а під ним - зруйнована дерев'яна кладка та вугілля (залишки перекриття - ?). На глибині 1,35 м від рівня горизонту на підгрунті влаштовано склеп $(2,5 \times 0,9$ м) із міцних дубових брусів, скріплених цвяхами по кутах. Усередині - кістяк головою на захід, притулений до північної стінки склепу. Руки складено в ділянці поперека, ноги випростано. Інвентар: S-подібне кільце біля лівої скроні ${ }^{173}$.

55. Білів, курган № 21. $\mathrm{h}=0,8$ м, Ø 8,6 м. Приблизно на рівні горизонту виявлено поміст $(3,1 \times 2,4$ м) із обтесаних брусів, складених у два перпендикулярні ряди. Під ним, на глибині 1,2 м від рівня горизонту, на розчищеному підгрунті підсипка 3 синюватого глею та золи з вугіллям, а на ній - труна $(2,05 \times 0,55$ м $)$ із товстих брусів. Скелет лежав головою на захід, руки та ноги випростані. Інвентар: поблизу шиї - підковоподібна фібула; на лівому плечі - ще одна, менша; біля правої кисті - залізний ніж; уздовж правої гомілкової кістки - залізний інструмент на зразок щипців (пінцет - ?); біля ступень залізні залишки відра ${ }^{174}$.

56. Білів, курган № 22. $\mathrm{h}=0,95 \mathrm{M}, \varnothing \approx$ 5,7 м. На глибині 1,6 м від вершини виявлено дощатий поміст, а на 0,15 м нижче - кришку домовини. Останню $(2,4 \times 0,6$ м) зведено 3 товстих дубових брусів на зольній підсипці. Скелет лежав головою на захід із випростаними руками. Поховання безінвентарне ${ }^{175}$.

57. Городськ, курган № $1 . \mathrm{h}=1,55 \mathrm{~m}, \varnothing \approx$ 12 м. На рівні горизонту - шар жовтого піску, а під ним - кілька дубових, обкладених берестою брусів шириною 0,3 м - залишки заваленого перекриття. На 0,3 м нижче - погано збережений кістяк у випростаному стані, головою на захід. Інвентарю немає ${ }^{176}$.

58. Київ-1, поховання б/№ 2002 р. по вул. Великій Житомирській, 2. Поховання було пограбоване в XI ст. На дні великої $(3,33 \times 1,24$ м) могильної ями, на глибині 2,2 м від сучасної поверхні, зафіксовано яму менших розмірів $(2,24 \times 0,9 \times 0,73 \mathrm{м})$; обидві орієнтовані за віссю південний захід - північний схід. Менша яма була зверху перекрита суцільним накатом із 17 колод діаметром 0,1-0,15 м. У ній виявлено труну $(2,5 \times 0,58 \times 0,3 \mathrm{M})$, скріплену 17 залізними цвяхами. Інвентар: під черепом - дві срібні 
177 Мовчан, I. I., Гончар, В. М., Iєвлев, М. М., \& Козловський, А. О. Звіт про археологічні дослідження, 3-27;

Мовчан, I. I., Боровський, Я. Є., Гончар, В. М., \& Ієвлев, М. М. Дослідження в «городі» Володимира, 190.

178 Cynkalowski, A. Materiały do pradziejów Wołynia I Polesia, 159.

179 Мовчановський, Ф. М. Щоденний керівника, 69; Довженок, В. Й. Огляд археологічного вивчення, 9๑; Зоценко, В. М. (2007). Скандинавські старожитності

Вишгорода. В Старожитності Вишгородщини: 36. тез, доповідей $i$ повідомлень 13-ї наук.-практ. конферениї̈, присвяч. «Дню пам'яті Ярослава Мудрого», 24-25 травня 2007 р., м. Вишгород (с. 58-59). Вишгород: Вишгородський історико-культурний заповідник; Андрощук, Ф., \& Зоценко, В. (2012). Скандинавские древности Южой Руси. Каталог. Paris: ACHCByz, 83.

180 Мовчановський, Ф. М. Щоденник керівника, 70-71.

181 Каргер, М. К. Древний Киев, 177.
3 позолотою лунниці, орнаментовані зерню; біля правого стегна - залізний ніж; у заповненні - позолочений срібний гудзик із петелькою, срібне скроневе кільце, набір із 10 скляних, пастових і кришталевої намистин, золота кулька від ювелірного виробу ${ }^{177}$.

\section{3. Камери невизначеної конструкції}

59. Понебель, поховання б/№. Під курганним насипом виявлено дерев'яний зруб, а всередині - один людський кістяк ${ }^{178}$.

60. Вишгород, поховання № 2/1936 на садибі Дорошенка. Могильну яму $(1,83 \times 1,47$ м $)$ вдалося простежити на глибину 0,7 м (верхня частина поховальної споруди і курганний насип могли бути знищені в давнину). Чоловічий кістяк лежав головою на захід. Навколо нього в кількох місцях зафіксовано сліди зотлілого дерева. Інвентар: між черепом і правим плечем померлого - залізний ніж iз залишками дерев'яного руків'я, залізне калачеподібне кресало та бронзове кільце 3 залишками тканини (як вважали дослідники, від торбини, в якій лежали ніж та кресало); 3 цим поховальним комплексом іноді пов'язують скандинавську за походженням кільцеву фібулу ${ }^{179}$.

61. Вишгород, поховання б/№ на садибі Дорошенка. Зафіксовано пограбовану мо- гильну яму $(2,2 \times 2$ м) із великою кількістю фрагментів гончарної та ліпної кераміки ${ }^{180}$.

62. Київ, поховання 111. Підпрямокутна могильна яма $(2,15 \times 1,1$ м) простежена на висоту $0,3-0,7$ м. Уздовж північно-східної стінки могильної ями зафіксовано чоловічий кістяк, що лежав на правому боці з підігнутою лівою ногою, головою на північний захід. Ліворуч від нього - жіночий скелет - на правому боці, з сильно підігнутими ногами. За М. К. Каргером, жінку було поховано в сидячому положенні. Інвентар: під тазовими кістками чоловічого скелета - чотири фрагменти срібного персня, вістря списа, вістря стріли та уламок кольчуги з залізних кілець; біля його правої ступні - бронзове кільце; золота тринамистинна сережка; два фрагменти круглої підвіски з ажурним решітчастим плетінням; фрагмент залізного ключа, шість уламків скляних браслетів; шиферний оселок ${ }^{181}$

63. Київ-II, «курган-могиканин» (поховання 118). $\mathrm{h}=2 \mathrm{м}, \varnothing \approx 12,5$ м. Поховання виявилося пограбованим іще в давнину. Під курганним насипом виявлено прямокутну могильну яму $(4,5 \times 3,15 \times 1,5$ м), орієнтовану за віссю північний схід - південний захід. У північно-західній частині лежав кістяк із випростаними кінцівками, головою на південний схід. За М. Ф. Біляшівським, похованих могло бути троє. Інвентар: біля лівої 
182 Беляшевский, Н. Ф. (1903). Курган-могикан на территории Киева. Археологическая летопись Южной России, 6, 357-361; Каргер, М. К. Древний Киев, 190-196; Зоценко, В. Н. Киевский некрополь II, 456-457.

183 Мовчан, I. I., \& Климовський, С. I. Дослідження «граду Ярослава», 93.

184 Кубишев, А. I. Стародавній Китаїв, 51.

185 Там же; Мовчан, I. I. Давньокиївська околиця, 157

186 Мовчановський, Ф. М. Щоденник керівника, 69; Довженок, В. И. Огляд археологічного вивчення, 90.

187 Мовчановський, Ф. М. Щоденник керівника, 69; Довженок, В. И. Огляд археологічного вивчення, 90.

188 Лебединцев, П. Г. О раскопке на Софийском дворе, 64; Антонович, В. Б. Археологическая карта, 36. руки - три пастові намистини та бронзовий гудзик; поблизу правої ступні - кістяна накладка (на колчан?), залізна шпора та бронзове кільце; між гомілками - дерев'яна чаша зі срібною накладкою; в північному куті могильної ями - ще одна залізна шпора, залізний предмет і бронзова ручка від кресала; в центральній частині ями - мініатюрна скляна посудина ${ }^{182}$.

64. Київ-I, поховання б/№ 2001 р. по вул. Рейтарській, 4. Поховання було пограбоване ще в давнину. Воно було здійснене в ямі $(2,95 \times 1,4 \times 0,9$ м), орієнтованій за віссю захід - схід. В ії заповненні чітко читалися сліди деревного тліну, виявлено 17 залізних цвяхів. Рештки кістяка жінки 30-40 років були складені по краях могильної ями. За пропорціями черепа можна припускати скандинавське походження померлої. Інвентар: відерце $з$ сосни $з$ залізним окуттям (імовірно, виготовлене спеціально для поховальної церемонії), велика ремінна пряжка, кільце кілька платівок від невизначеного виробу ${ }^{183}$

65. Китаїв-1, поховання б/№ із розкопок О. Д. Ертеля. Серед досліджених курганів кілька мали дерев'яні обкладки стін, а іноді - й дна, могильних ям. Крім того, деякі $з$ них містили й «рухомі» гробовища ${ }^{184}$.

66. Китаїв - 3, поховання б/№ із розкопок О. Д. Ертеля. В ямі, обкладеній по боках товстими дошками, виявлено кістяки жінки (по центру) та двох чоловіків. Верхня частина одного з них була розсічена до самого таза; відрубаної лівої частини черепа немає. На думку автора розкопок, тіло могло бути не розсічене, а розпиляне після смерті ${ }^{185}$.

\section{1. Поховання 3 сумнівною атрибуцією}

Вишгород, поховання № 1/1936 на садибі Дорошенка. Поховальна споруда була аналогічною 3 похованням № 2 (див. вище). Кістяк, верхню частину якого було знищено внаслідок земляних робіт, мав північно-західне орієнтування. Інвентар: у головах - перекинутий горщик; у заповненні ями - кілька фрагментів ліпного посуду, амфорні вінця та ціла амфора ${ }^{186}$.

Вишгород, поховання № 3/1936 на садибі Дорошенка. Поховальна споруда була аналогічною 3 похованням № 2 (див. вище). В похованні зафіксовано кістяк східного орієнтування. Інвентар: $з$ обох боків черепа - срібні скроневі кільця ${ }^{187}$.

Київ-I, поховання 103. На глибині $\approx 2,8$ м від денної поверхні, «в смузі вугілля» (?) виявлено людський скелет і кістки коня. Інвентар: залізні стремена і «кинджал» (?); за словами В. Б. Антоновича, також виявлено спис, вудила і пряжки ${ }^{188}$. 
189 Хойновский, И. А. Раскопки великокняжеского двора, 24.

190 Каргер, М. К. Древний Киев, 208-210; Зоценко, В. Н. Киевский некрополь II, 460-464.

191 Антонович, В. Б. Археологические находки, 251-252; Антонович, В. Б. 0 древнем кладбище, 43; Каргер, М. К. Древний Киев, 210-211; Андрощук, Ф. Скандинавские древности, 39-40; Зоценко, В. Н. Киевский некрополь, 464-466.
Київ-I, поховання 107. У грунтовій могилі, на підлозі з дощок, поруч виявлено кістяки чоловіка та жінки. Інвентар: бронзовий (?) перстень із розеткою на щитку на руці у жінки, кістяне вістря стріли, амфора, скляна посудинка ${ }^{189}$.

Київ-II, поховання 124. Характер поховальної споруди невідомий. Крім поховального інвентарю, виявлено залізний цвях. Інвентар: дві бронзові позолочені овальні фібули, срібна кругла фібула, пара скроневих кілець волинського типу, срібна сережка 3 пастовою намистиною, кільце 3 золотого дроту, намисто з десяти пастових, трьох сердолікових (двох 14-гранних і однієї біпірамідальної 8-гранної), трьох кришталевих, однієї скляної та однієї бурштинової намистин, срібна прямокутна підвіска, бронзова хрестоподібна підвіска, дві візантійські монети (931-944рр.) ${ }^{190}$.

Київ-II, поховання 125. У грунтовій могилі, облаштування якої не описане, виявлено кістяк західного орієнтування. Ф. А. Андрощук і В. М. Зоценко вважали поховання 117 і 125 єдиним комплексом. Інвентар: у ділянці плечей -2 срібні позолочені овальні фібули; біля шиї - 2 срібні хрестоподібні підвіски (за іншими даними, овальні фібули та хрестоподібні підвіски знайдено в ділян- ці пояса, що може вказувати на сидяче положення небіжчиці) та намисто 36 скляних i 1 пастової намистин і підвіски-дирхема (142/759-760р.); біля черепа - 4 срібні та 1 золота сережки 3 напускними кришталевими, пастовими або скляними намистинами; в ділянці поперека - точильний брусок з отвоpom ${ }^{191}$.

\section{References}

Androshchuk, F. A. (1999). Normany $i$ slov'iany u Podesenni. Kyiv: Tovarystvo arkheolohii ta antropolohii [in Ukrainian].

Androshchuk, F. (2004). Skandinavskie drevnosti v sotsialnoi topografii drevnego Kieva, Ruthenica, III, 7-47 [in Russian].

Androshchuk, F., Panchenko, M., \& Kovaliukh, M. (1996). Do peredistorii sporudzhennia Desiatynno tserkvy (khronolohichnyi analyz pokhovalnykh kompleksiv). In Tserkva Bohorodytsi Desiatynna v Kyievi. Do 1000-littia osviachennia (pp. 43-46). Kyiv: ArtEk [in Ukrainian].

Androshchuk, F., \& Zotsenko, V. (2012). Skandinavskie drevnosti Iuzhnoi Rusi. Katalog. Paris: ACHCByz [in Russian].

Antonovich, V. B. (1879). Arkheologicheskie nakhodki i raskopki v Kieve i v Kievskoi gubernii v techenie 1876 g. In Chtenija v Istoricheskom obshhestve Nestora-letopisca (Vol. 1, pp. 244-261, 282) [in Russian]

Antonovich, V. B. (1884). O drevnem kladbishche u Iordanskoi tserkvi v Kieve (o rezultatakh raskopok, proizvedennykh v severnom uglu goroda Kieva. In Tru- 
dy IV Arheologicheskogo s\#ezda v Kazani (Vol. I, pp. 42-44) [in Russian].

Antonovich, V. B. (1893). Raskopki v strane drevlian. Materialy po arheologii Rossii, 11 [in Russian]

Antonovich, V. B. (1895). Arkheologicheskaia karta Kievskoi gubernii (Prilozhenie k 15 t. "Drevnosti") Moskva: Tipografiia M. G. Volchaninova [in Russian].

Avdusin, D. A., \& Pushkina, T. A. (1989). Tri pogrebalnye kamery iz Gnezdova. In Istoriia i kultura drevnerusskogo goroda (pp. 190-205). Moskva: Izdatelstvo MGU [in Russian].

Avlasovich, A. M. (2015). Issledovanie sidiachego pogrebeniia radimichanki $\mathrm{v}$ kurgannom nekropole $\mathrm{u}$ d. Studenka Bykhovskogo raiona. In Bykhovskie kraevedcheskie chteniia. IV nauchno-prakticheskaia konferentsiia, posviashchennaia 100-letiiu so dnia nachala Pervoi mirovoi voiny, 30 dekabria 2014 g., g. Bykhov (pp. 54-60). Bykhov [in Russian].

Beliashevskii, N. F. (1903). Kurgan-mogikan na territorii Kieva. Arheologicheskaja letopis' Juzhnoj Rossii, 6, 357-361 [in Russian].

Bibikov, D. V. (2019). Kryterii vydilennia kamernykh pokhovan epokhy vikinhiv u Cerednomu Podniprov'i: suchasnyi stan problemy. In I Vseukrainskyi arkheolohichnyi z'izd: materialy roboty (pp. 433-446) Kyiv: Instytut arkheolohii NAN Ukrainy [in Ukrainian]

Bibikov, D. V. (2020). Relihiina nalezhnist davnoruskykh kamernykh pokhovan. Arkheolohiia, 1, 61-71 [in Ukrainian].

Blifeld, D. I. (1977). Davnoruski pam'iatky Shestovytsi. Kyiv: Naukova dumka [in Ukrainian].

Borovskii, Ia. E., Arkhipova, E. I., Kaliuk, A. P., \& Syromiatnikov, A. K. (1988). Arkheologicheskie issledovaniia v "Verkhnem Kieve" v 1988 g. (Otchet o raskopkakh po ul. B. Zhitomirskoi, 2 i nabliudeniiakh za zemlianymi rabotami v "Verkhnem gorode" v $1988 \mathrm{~g}$ Naukovyi arkhiv Instytutu arkheolohii NANU, F.e., № 1988/17.
Borovskyi, Ya. Ye., \& Kaliuk, O. P. (1993). Doslidzhennia kyivskoho dytyntsia. In Starodavnii Kyiv Arkheolohichni doslidzhennia 1984-1989 rr. (pp. 3-42) Kyiv: Naukova dumka [in Ukrainian].

Cynkalowski, A. (1961). Materiaty do pradziejów Wotynia I Polesia Wotyńskiego. Warszawa: PTA.

Dovzhenok, V. Y. (1950). Ohliad arkheolohichnoho vyvchennia drevnoho Vyshhoroda za 1934-1937 rr Arkheolohiia, 3, 64-92 [in Ukrainian].

Geze, V. (1905). Zametki o nekotorykh kievskikh drevnostiakh. Zapiski otdelenija russkoj i slavjanskoj arheologii Russkogo arheologicheskogo obshhestva, 7 (1), $143-146$.

Golubeva, L. A. (1949). Kievskii nekropol. Materialy $i$ issledovanija po arheologii SSSR, 11, 103-118 [in Russian].

Gräslund, A.-S. (1980). Birka IV: The Burial Customs. A study of the graves on Bjorko. Stockholm: Almqvist \& Wiksell.

Hamchenko, S. S. (1927). Rozkopy 1926 roku v Kyievi (davnisha sadyba V. P. Trubetskoho). In Korot ke zvidomlennia Vseukrainskoho arkheolohichnoho komitetu za 1926 r. (pp. 17-32). Kyiv [in Ukrainian].

Honcharov, V. K. (1949). Arkheolohichna rozvidka po r. Rostavytsi v 1946 r. In Arkheolohichni pam'iatk URSR (Vol. 1, pp. 237-245) [in Ukrainian]

Izvestija Imperatorskoj arheologicheskoj komissii. (1909). Pribavleniia k Vyp. 32.

Ivakin, G. Iu., Ioannisian, O. M., \& Elshin, D. D. (2010). Arkhitekturno-arkheologicheskie issledovaniia Desiatinnoi tserkvi v Kieve 2008-2009 godakh. In Trudy Gosudarstvennogo Ermitazha (T. 53. Arkhitektura Vizantii i Drevnei Rusi IX-XII vekov, pp. 377-390) Sankt-Peterburg: Izdatelstvo Gosudarstvennogo Ermitazha [in Russian].

Ivakin, H. Yu., Ioannisian, O. M., Yolshyn, D. D., \& Lukomskyi, Yu. V. (2012). Doslidzhennia Desiatyn- 
noi tserkvy v Kyievi u 2007-2008 rr. In Materialna ta dukhovna kultura Pivdennoi Rusi. Materialy Mizhnarodnoho polovoho arkheolohichnoho seminaru, prysviachenoho 100-littiu vid dnia narodzhennia V.Y. Dovzhenka (Chernihiv-Shestovytsia, 16-19 lypnia 2009 r.) (pp. 130-138). Kyiv; Chernihiv: Chernihivskyi natsionalny pedahohichnyi universytet imeni T. H. Shevchenka [in Ukrainian]

Ivakin, H. Yu., \& Koziuba, V. K. (2003). Novi pokhovannia X-XI st. Verkhnoho Kyieva (z rozkopok Arkhitekturno-arkheolohichnoi ekspedytsii 1997-1999 rr.). In Druzhynni starozhytnosti Tsentralno-Skhidnoi Yevropy VIII-XI st. (pp. 38-50). Chernihiv: Siverianska dumka [in Ukrainian].

Ivakin, H. Yu., Kozubovskyi, H. A., Koziuba, V. K., Poliakov, S. Ye., \& Chmil, L. V. (1999). Doslidzhennia na terytorii Mykhailivskoho Zolotoverkhoho monastyria u 1998-1999 rr. Arkheolohichni vidkryttia v Ukraini 1998-1999, 5-6 [in Ukrainian]

Ivakin, V. G. (2011). Kievskie pogrebeniia X veka. Stratum plus, 5, 1-44 [in Russian].

Ivakin, V. H. (2008). Khrystyianski pokhovalni pam'iatky davnoruskoho Kyieva. Kyiv: KNT [in Ukrainian].

Ivakin, V. H. (2012). Kyivski pokhovalni kamery. In Materialy Mizhnarodnoho polovoho arkheolohichnoho seminaru, prysviachenoho 100-littiu vid dnia narodzhennia V.Y. Dovzhenka (Chernihiv-Shestovytsia, 16-19 lypnia 2009 r.) (pp. 122-129). Kyiv; Chernihiv: Chernihivskyi natsionalnyi pedahohichnyi universytet imen T. H. Shevchenka [in Ukrainian].

Janowski, A. (2015). Groby komorowe w Europie Środkowo-Wschodniej. Problemy wybrane. Szczecin: IAE PAN.

Karger, M. K. (1940). Pogrebenie kievskogo druzhinnika X v. Kratkie soobshhenija Instituta istorii material'noj kul'tury AN SSSR, V, 79-82 [in Russian].
Karger, M. K. (1947). Kievskaia ekspeditsiia (1846 g.). Kratkie soobshhenija Instituta istorii material'noj kul'tury AN SSSR, XXI, 38-40 [in Russian].

Karger, M. K. (1958). Drevnii Kiev (T. 1). Moskva; Leningrad: Izdatelstvo Akademii nauk SSSR [in Russian].

Khamaiko, N. (2014). Kamerni pokhovannia nekropolia Desiatynnoi tserkvy: problemy interpretatsii. Opus mixtum, 2, 137-147 [in Ukrainian].

Khamaiko, N. (2018). Pokhovannia konia X stolittia iz sadyby Trubetskykh u Kyievi. Opus mixtum, 6, 105122 [in Ukrainian]

Khoinovskii, I. A. (1893). Raskopki velikokniazheskogo dvora drevnego Kieva, proizvedennye v 1882 godu. Kiev: Tipografiia S. V. Kulzhenko [in Russian].

Kilievich, S. R. (1973). Issledovaniia na territori Velikogo kniazhego dvora v Kieve. Arheologicheskie ot krytija 1972, 285-286 [in Russian].

Kilievich, S. R. (1982). Detinets Kieva IX - pervo poloviny XIII v. Kiev: Naukova dumka [in Russian].

Kilievich, S. R., \& Kharlamov, V.A. (1986). Raskopki Fedorovskogo monastyria v Kieve. Arheologicheskie otkrytija 1984, 241 [in Russian].

Kirpichnikov, A.N., Lebedev, G. S., Bulkin, V. A., Dubov, I. V., \& Nazarenko, V. A. (1980). Russko-skandinavskie sviazi epokhi obrazovaniia Kievskogo gosudarstva na sovremennom etape arkheologicheskogo izucheniia. Kratkie soobshhenija Instituta arheologii AN SSSR, 160, 24-38.

Kopylov, F. B. (1951). Zrubne pokhovannia bilia Desiatynnoi tserkvy. Arkheolohiia, V, 233-235 [in Ukrainian].

Korzukhina, G. F. (1946). O tekhnike tisneniia peregorodchatoi emaliv drevnei Rusi X-XII vv. Kratkie soobshhenija Instituta istorii material'noj kul'tury AN SSSR, XIII, 45-54 [in Russian].

Kubyshev, A. I. (1964). Starodavnii Kytaiv. Arkheolohiia, XVII, 43-55 [in Ukrainian]. 
Lebedintsev, P. G. (1888). O raskopke na Sofiiskom dvore v mae $1878 \mathrm{~g}$. In Chtenija v Istoricheskom obshhestve Nestora-letopisca (Vol. II (1), p. 64) [in Russian]

Lesman, Iu. M. (1997). Kvazikamernoe pogrebenie v mogilnike Struiskoe na Verkhnei Volge i problema proiskhozhdeniia drevnerusskikh sidiachikh pogrebenii. In XIII konferentsiia po izucheniiu istorii, ekonomiki, literatury i iazyka skandinavskikh stran i Finliandii (pp 180-183). Petrozavodsk [in Russian].

Lesman, Iu. M. (2014). Skandinavskii komponen drevnerusskoi kultury. Stratum plus, 5, 43-93 [in Russian].

Livokh, R. (2010). Bolshie kurgany letopisnogo Plesneska. In Slaviano-russkoe iuvelirnoe delo i ego is toki. Materialy Mezhdunarodnoi nauchnoi konferentsii, posviashchennoi 100-letiiu so dnia rozhdeniia Galiny Fedorovny Korzukhinoi (Sankt-Peterburg, 10-16 aprelia 2006 g.) (pp. 486-492). Sankt-Peterburg: Nestor-Istoriia [in Russian].

Liwoch, R. (2018). Zabytki z wykopalisk Teodora Nieczuja-Ziemięckiego $w$ latopisowym Pleśnisku (Podhorce na Ukrainie) / Artefacts from Excavations by Teodor Nieczuja-Ziemięcki in Mediaeval Plisnes'k (Pidgìrcì in Ukraine). Kraków: Museum archeologiczne w Krakowie.

Melnik, E. N. (1901). Raskopki v zemle luchan. In Trudy XI Arheologicheskogo s\#ezda (Vol. 1, pp. 479 513) [in Russian].

Melnikova, E. A., \& Petrukhin, V. Ia. (1986) Formirovanie seti rannegorodskikh tsentrov i stanovlenie gosudarstva (Drevniaia Rus i Skandinaviia). Istoriia SSSR, 5, 64-78 [in Russian].

Mikhailov, K. A. (2016). Elitarnyi pogrebalnyi obriad Drevnei Rusi: kamernye pogrebeniia IX-nachala XI veka v kontekste severoevropeiskikh analogii. Sankt-Peterburg: Branko [in Russian].
Motsia, O. P. (2019). Shche raz pro elitarnyi pokhovalnyi obriad yazychnytskoi Rusi. Arkheolohiia, 2 48-60 [in Ukrainian].

Movchan, I., Borovskyi, Ya., \& Honchar, V. (2003) Novi znakhidky z druzhynnoho nekropolia Verkhnoho Kyieva. In Druzhynni starozhytnosti Tsentralno-Skhidnoi Yevropy VIII-XI st. (pp. 114-120). Chernihiv: Siverianska dumka [in Ukrainian].

Movchan, I. I. (1973). Otchet o raskopkakh Kitaevskogo poseleniia i mogilnika. Naukovyi arkhiv Instytutu arkheolohii NANU, f. e., 1973/22 [in Russian].

Movchan, I. I. (1993). Davnokyivska okolytsia. Kyiv: Naukova dumka [in Ukrainian].

Movchan, I. I., Borovskyi, Ya. Ye., Honchar, V. M., \& Iievlev, M. M. (2003). Doslidzhennia v "horodi" Volodymyra Starodavnoho Kyieva. In Arkheolohichni vidkryttia v Ukraini 2001-2002 (pp. 187-191) [in Ukrainian].

Movchan, I. I., Honchar, V. M., Iievlev, M. M., \& Kozlovskyi, A. O. (2002). Zvit pro arkheolohichni doslidzhennia na vul. Velyka Zhytomyrska, 2. Naukovyi arkhiv Instytutu arkheolohii NANU, f. e., № 2002/84 [in Ukrainian].

Movchan, I. I., \& Klymovskyi, S. I. (2002). Doslidzhennia "hradu Yaroslava" Starodavnoho Kyieva. In Arkheolohichni vidkryttia v Ukraini 2001-2002 (pp. 192-195) [in Ukrainian].

Movchanovskyi, F. M. (1936). Shchodennyk kerivnyka Vyshhorodskoi ekspedytsii IIMK (05.09 26.09.1936 r.). Naukovyi arkhiv Instytutu arkheolohii NANU,f. 20, № 42 [in Ukrainian].

Müller-Wille, M. (2014). The Cemetery at Bodzia in a Broader European Context. In Bodzia: A Late Viking-Age Elite Cemetery in Central Poland (pp. 477510). Leiden-Boston: Brill

Otchet Imperatorskoj arheologicheskoj komissii za 1908 g. (1912). Sankt-Peterburg [in Russian]. 
Pasternak, Ya. (1948). Litopysnyi horod Plisnesk ta problema variahiv u Halychyni. Naukovyi zbirnyk Ukrainskoho vilnoho universytetu, 5, 138-148 [in Ukrainian]

Petrukhin, V. Ia. (1993). Variagi i khazary v istorii Rusi. Etnograficheskoe obozrenie, 3, 68-83 [in Russian]

Plavinskii, N. A. (2014). Nekotorye rezultaty raskopok srednevekovykh pogrebalnykh pamiatnikov Braslavskogo Poozeria arkheologicheskoi ekspeditsie Natsionalnogo istoricheskogo muzeia Respubliki Belarus. In Vésture: avoti un cilvēki (pp. 304-312). Daugavpils: Daugavpils Universitātes Akadēmiskais apgāds "Saule" [in Russian].

Plavinskii, N. A., \& Vasilev, V. M. (2018). "Pogrebalnaia kamera" ili net? Vozmozhnye puti transformatsi "kamernogo" obriada na territorii Polotskoi zemli v kontse X-XI vv. In Arkheologiia Drevnei Rusi: problemy otkrytiia. Materialy mezhdunarodnoi konferentsii, posvi ashchennoi 100-letiiu so dnia rozhdeniia D. A. Avdusina (pp. 63-64). Moskva: Pamiatniki istoricheskoi mysli [in Russian].

Priimak, V. V. (2018). Podkovoobraznye fibuly iz drevnerusskikh pamiatnikov Levoberezhia Dnepra. Filo Ariadne, 3. Retrieved from http://filoariadne.esrae.ru/ pdf/2018/3/230.pdf [in Russian].

Ratych, O. O. (1971). Bahate pokhovannia rubezhu X-XI st. u Sudovii Vyshni. In Seredni viky na Ukraini (Vol. 1, pp. 162-168). Kyiv: Naukova dumka [in Ukrainian].

Rusanova, I. P. (1973). Slavianskie drevnosti VIIX vv. mezhdu Dneprom i Zapadnym Bugom. In Svod arheologicheskih istochnikov (Vol. E1-25). Moskva: Nauka [in Russian].

Samoilovskyi, I. M. (1954). Slov'ianskyi mohylnyk na r. Pronivshchyni pid Kyievom. Arkheolohiia, 3, 184 188 [in Ukrainian].
Samokvasov, D. Ia. (2016). Mogilnye drevnosti severianskoi Chernigovshchiny. Moskva: Sinodalnaia tipografiia [in Russian].

Sedov, V. V. (1982). Vostochnye slaviane v VIXIII vv. Arkheologiia SSSR, 2 [in Russian].

Sedova, M. V. (1981). Iuvelirnye izdeliia drevnego Novgoroda $(X-X V v v$.). Moskva: Nauka [in Russian].

Serhieieva, M. S. (2015). Maistry z obrobky dereva ta kistky davnoruskoho mista Voinia. Kyiv; Kharkiv: Maidan [in Ukrainian]

Shinakov, E. A. (1995). Ot prashchi do skramasaksa: na puti k derzhave Riurikovichei. Briansk; Sankt-Peterburg: Brianskii gosudarstvennyi universitet imeni akademika I. G. Petrovskogo [in Russian].

Shinakov, E. A., Gurianov, V. N., \& Chubur, A. A (2011). Pogrebalnyi obriad v Srednem Podesene kak istochnik dlia istoricheskoi rekonstruktsii. Briansk: Kursiv [in Russian].

Shteingel, F. R. (1905). Raskopki kurganov $v$ Volynskoi gubernii, proizvedennye v 1897-1900 gg. Kiev: Tipografiia N. A. Girich [in Russian].

Sobolev, V. Iu. (1997a). Kamernoe zakhoronenie v mogilnike Rapti-Navolok II v kontekste stanovleniia drevnerusskogo pogrebalnogo obriada. In XIII konferentsiia po izucheniiu istorii, ekonomiki, literatury i iazyka skandinavskikh stran i Finliandii. Tezisy dokladov (pp. 183-185). Petrozavodsk [in Russian].

Sobolev, V. Iu. (1997b). O drevnerusskikh kamernykh pogrebeniiakh Novgorodskoi zemli. Pamiatniki stariny. Kontseptsii. Otkrytiia. Versii. Pamiat V. D. Beletskogo (Vol. II, pp. 272-277). Sankt-Peterburg Pskov: Nevelskaia tipografiia [in Russian].

Sobolev, V. Iu. (2018). Kamery, domoviny, groby. Sudba severoevropeiskoi pogrebalnoi traditsii Novgorodskoi zemle XI-XII vv. In Arkheologiia Drevnei Rusi: problemy i otkrytiia. Materialy mezhdunarodnoi konferentsii, posviashchennoi 100-letiiu so dnia rozh- 
deniia D. A. Avdusina (pp. 66-67). Moskva: Pamiatniki istoricheskoi mysli [in Russian].

Sytyi, Iu. N. (2011). Mogily khristian Chernigova $\mathrm{X}$ veka (k postanovke problemy). In Khristiianizatsiin vplivi v Kï̈skii Rusi za chasiv kniazia Oskolda: 1150 rokiv. Materiali mizhnarodnoï naukovoï konferentsii, 19-20 listopada 2010 r. (pp. 98-110). Chernigiv; Lutsk: Teren [in Russian].

Sytyi, Yu. M. (2009). Kamery, "psevdokamery" ta mohyly Chernihivskoho nekropolia. In Chernihivski starozhytnosti (Vol. II, pp. 292-296). Chernihiv [in Ukrainian].

Tolochko, P. P. (2009). Istoricheskaia topografiia rannego Kieva: realnaia i vymyshlennaia. Ruthenica, 8 , 151-183 [in Russian].

Tymoshchuk, B. O. (1982). Davnoruska Bukovyna (X-persha polovyna XIV st.). Kyiv: Naukova dumka [in Ukrainian].

Velmin, S. P. (1910). Arkheologicheskie izyskaniia v Imperatorskoi arkheologicheskoi komissii v 1908-1909 godakh na territorii Drevnego Kieva. Voenno-istoricheskii vestnik, 7-8, 121-153 [in Russian].

Voitekhovich, A. V. (2019). Pogrebalnyi obriad naseleniia Polotskoi zemli $v$ X-XII vv. Minsk: Belaruskaia navuka [in Russian].

Vyiezzhiv, R. I. (1954). Rozkopky kurhaniv u Korosteni ta poblyzu Ovrucha v 1911 r. Arkheolohiia, 9, 145 153 [in Ukrainian].

Zharnov, Iu. E. (1991). Zhenskie skandinavskie pogrebeniia v Gnezdove. In Smolensk $i$ Gnezdovo (pp 200-225). Moskva: Izdatelstvo MGU [in Russian].
Zharnov, Iu. E. (1998). Gnezdovskie kurgany s ostatkami trupopolozheniia. In Istoricheskaia arkheologiia. Traditsii i perspektivy (k 80-letiiu so dnia rozhdeniia Daniila Antonovicha Avdusina) (pp. 92-105). Moskva: Pamiatniki istoricheskoi mysli [in Russian].

Zotsenko, V. M. (2007). Skandynavski starozhytnosti Vyshhoroda. In Starozhytnosti Vyshhorodshchyny: Zb. tez, dopovidei i povidomlen 13-i nauk.-prakt. konferentsii, prysviach. "Dniu pam'iati Yaroslava Mudroho", 24-25 travnia 2007 r., m. Vyshhorod (pp. 43-70). Vyshhorod: Vyshhorodskyi istoryko-kulturnyi zapovidnyk [in Ukrainian].

Zotsenko, V. N. (2009). Kievskii nekropol II: mesto $\mathrm{v}$ istoricheskii topografii goroda, tipologiia inventaria, khronologiia. In Slaviano-russkoe iuvelirnoe delo i ego istoki. Materialy Mezhdunarodnoi nauchnoi konferentsii. posviashchennoi 100-letiiu so dnia rozhdeniia Galiny Fedorovny Korzukhinoi (Sankt-Peterburg, 10-16 aprelia 2006 g.) (c. 442-465). Sankt-Peterburg: Nestor-Istoriia [in Russian].

Zozulia, S. S. (2012). Datirovka kamernogo pogrebeniia $\mathrm{v}$ kurgane 348 Timerevskogo mogilnika Rossiiskaia arkheologiia, 4, 90-98 [in Russian].

Zozulia, S. S. (2014). K voprosu ob osobennostiakh kamernogo obriada pogrebeniia $\mathrm{v}$ Iaroslavskom Povolzhe. Pogrebeniia v kurganakh 100 i 459 Timerevskogo arkheologicheskogo kompleksa. In XIV Tikhomirovskie kraevedcheskie chteniia: Materialy nauchnoi konferentsii (pp. 233-243). Iaroslavl: Iaroslavskii gosudarstvennyi istoriko-arkhitekturnyi i khudozhestvennyi muzei-zapovednik [in Russian]. 


\section{CHAMBER GRAVES AND THEIR IMITATIONS ON THE RIGHT BANK OF THE DNIPER: WAYS OF EVOLUTION OF THE ELITE FUNERAL RITE}

The article is devoted to a specific category of ancient Rus burial monuments of X-XI centuries. They combine the features of both elite chamber tombs of the Viking Age and ordinary Christian burials of the beginning of the II millennium AD. The author considered to combine such burials under the term "pseudo-chambers" or "imitation chambers". There are four types of them: 1) chambers with coffins; 2) ground chambers; 3 ) "earthen" chambers with wooden flooring, but without wall coverings; 4) "large burial pits" without wooden structures. In the article there is analysis of the structural and ceremonial features of each of these chamber types. Moreover, the author identifies their peculiarities. Obviously, the erection of classical chamber tombs in the southern Rus territories ceased with the beginning of Christianization. However, the ancient Rus elite could not abandon this tradition completely, which was reflected in the appearance of imitation cameras. The vast majority of them inside permanent wooden structures contain a movable coffin. This fact contradicts the basic idea of the classical chamber tombs as "houses of the dead" and indicates at least a significant influence of the Christian doctrine. The spread of pseudo-chambers in the territory of Volyn should undoubtedly be linked to the governmental activity of Volodymyr Sviatoslavych that may have been accompanied by an influx of people ("greater men") from the Middle Dnieper. According to the composition of the funerary inventory and analogies from the adjacent territories, they can be dated from the end of $\mathrm{X}$ - the first half of XI centuries.

Comprehensive analysis of construction features and funerary inventory of imitation chambers does not allow us uniquely associate them with representatives of the ancient Rus elite. Within the region, mentioned monuments are not a direct line of development of classical chamber tombs, but merely imitate socially prestigious ceremonial elements of the latter.

Keywords: Ancient Rus, right bank of the Dnieper, funeral rite, flexed position. 